\title{
ESTUDO DO GENE btk (BRUTON'S TYROSINE KINASE) EM PACIENTES COM AGAMAGLOBULINEMIA CONGÊNITA
}

Tese apresentada ao Programa de Pós-Graduação Biotecnologia USP/Instituto Butantan/IPT para a obtenção do Título de Doutor em Biotecnologia.

São Paulo 


\section{ESTUDO DO GENE btk (BRUTON'S \\ TYROSINE KINASE) EM PACIENTES \\ COM AGAMAGLOBULINEMIA \\ CONGÊNITA}

Tese apresentada ao Programa de PósGraduação Biotecnologia USP/Instituto Butantan/IPT para a obtenção do Título de Doutor em Biotecnologia.

Área de Concentração: Imunologia

Orientadora: Prof ${ }^{a}$ Magda M. S. Carneiro-

Sampaio

São Paulo

2008 


\section{Dedíco}

\section{$\mathcal{A}$ Deus}

Fonte de minha sabedoria e vida, por estar sempre ao meu lado... 


\section{Ao André,}

Filho amado e precioso que Deus me deu a honra de ser sua mãe, que me perdoou pela longa ausêncía...

Aos Meus País,

A quem devo tudo o que sou, minha gratidão por ter me proporcionado a conquistar o bem mais valioso, o conhecimento. 
Aos pacientes e aos seus familiares

que sem a ajuda e colaboração este trabalho seria inviável...

$\mathcal{A}$ vocês minha eterna gratídão. 


\section{Agradecimentos}

A minha orientadora Prof ${ }^{a} D^{a}$ Magda M. S. Carneiro-Sampaio pela confiança em meu desempenho e pelo respeito e carinho que me acolheu em seu laboratório.

A Dra Beatriz Costa Carvalho pela amizade, carinho, e grande contribuição em minha vida profissional $e$ o socorro imediato sempre que precisei, obrigada.

A Dra Cristina Jacob pela ajuda na compreensão e na coleta das informações clínicas.

Ao Prof. Dr. Antonio Condino Neto, pelo apoio, incentivo e ajuda em um dos momentos mais difíceis deste trabalho, minha gratidão.

Ao Prof. Carlos Alberto Moreira Filho pela disponibilização do espaço e dos equipamentos em seu laboratório onde grande parte deste trabalho foi desenvolvido.

Ao Prof. Mario Hirata do Laboratório de Biologia Molecular do Departamento de Análises Clínicas pelo empréstimo do equipamento de análise do SSCP para a finalização desta etapa e a técnica Cristina pela disponibilidade em me recepcionar no laboratório de forma tão carinhosa.

A Cristina Kubo, amiga, incentivadora e conselheira em tantos momentos. Muito Obrigada.

A Patrícia Palmeira, profissional admirável, que sempre está disponivel a ajudar, e excelente conselheira. A você o meu muito obrigado!!!

A Beatriz e a Rúbia pela amizade e importante ajuda que vocês me deram no inicio deste trabalho.

As amigas queridas que tive a honra de conviver durante este trabalho $e$ que me ajudaram pelo simples fato de se tornarem amigas: Simone, Elaine, Ana Lúcia, Fabiana, Mariana e Dora.

A Gerlândia pelas contribuições na minha vida profissional e a Leuridan pela agradável convivência. 
A um grupo muito especial que chegou quase no fim, mas os laços criados se estenderão para sempre: Josias, Walmir, Paulo, Ângela e Otávio, á vocês obrigada por toda ajuda.

A Juliana, Edgar, Jussara, Patrícia, Mateo, Carol Prando e Carol, equipe maravilhosa do CIPED -UNICAMP.

Aos meus irmãos, sobrinhos e sobrinhas, a Clara Liz e Fernanda, minhas sobrinha-neta obrigado pelo amor de vocês e pela ajuda que nunca falhou, Muito Obrigada, amo vocês.

A Cristina Beerends, Márcia Candido, Flávia Lima e Isabel Zingra grandes amigas de toda uma vida. Obrigada por estarem sempre comigo.

A Socorro e a Luzinete por demonstrarem, além da competência profissional, o amor pelo trabalho que executam, meu carinho e minha admiração.

A equipe de enfermagem do Hospital Dia do Instituto da Criança FMUSP, pelas coletas do material biológico dos pacientes.

A todos aqueles que de uma forma indireta contribuíram para a finalização desta etapa.

A FAPESP pelo apoio financeiro. 
Do meu telescópio, eu via Deus caminhar! A maravilhosa disposição e harmonia do universo só pode ter tido origem segundo o plano de um Ser que tudo sabe e tudo pode. Isto fica sendo a minha última e mais elevada descoberta.

Isaac Newton 


\section{Resumo}

Oliveira, RR. Estudo do gene Btk (Bruton's Tyrosine Kinase) em pacientes com agamaglobulinemia congênita. [Tese]. São Paulo: Interunidades em Biotecnologia USP/Instituto Butantan/IPT; 2008.

A agamaglobulinemia ligada ao X (XLA) é uma imunodeficiência primária considerada como um protótipo de defeito no desenvolvimento precoce de células $\mathrm{B}$. Aproximadamente $85 \%$ dos pacientes com defeitos no desenvolvimento precoce de células B apresentam XLA, caracterizada por ausência ou níveis reduzidos de células $B$ maduras no sangue periférico e por níveis de imunoglobulinas séricas marcadamente reduzidos ( $\lg G<200 \mathrm{mg} / \mathrm{dL}$, $\lg M$ e $\lg A<2$ desvios padrão para a faixa etária). Meninos afetados normalmente apresentam uma maior susceptibilidade a infecções bacterianas e enterovirais graves. XLA é causada por mutações no gene $b t k$, o qual codifica para a proteína tirosino quinase de Bruton expressa em células hematopoiéticas. $\mathrm{O}$ gene btk está localizado no braço longo do cromossomo $\mathrm{X}$ na região q21.3-22. A proteína BTK é um membro da família Tec de tirosino quinases citoplasmáticas e desempenha papel modulador vital, porém diversificado, em muitos processos celulares. Cerca de 10 a $15 \%$ dos casos de Agamaglobulinemia não estão ligados ao $X$, são autossômicos recessivos, apresentando características fenotípicas semelhantes a XLA, mas ausência de mutações no gene btk. Trinta e três pacientes do sexo masculino foram incluídos neste estudo e analisados quanto à presença de mutações na BTK. A inclusão destes pacientes foi baseada em três critérios, de acordo com as recomendações do PAGID e ESID: ausência ou níveis de células $B$ circulantes inferiores a $2 \%$; baixos níveis de IgG sérica e história de infecções bacterianas recorrentes. Para todos os 33 pacientes realizamos o estudo do gene btk através da metodologia de triagem de mutação (SSCP/HA). Possíveis mutações foram caracterizadas por seqüenciamento direto e o perfil de expressão da BTK foi analisado através da técnica de PCR em tempo real. As infecções de repetição encontradas nesta casuística foram pneumonias, otites, sinusites, sepse e diarréia. Pacientes com grau de parentesco direto (pais ou irmãos), e albergando a mesma mutação apresentaram diferenças em suas manifestações clínicas. As 
mutações encontradas foram do tipo missense, nonssense, pequenas deleções/inserções e alterações em sítio de splicing, ao longo dos domínios $\mathrm{PH}$, $\mathrm{SH} 3, \mathrm{SH} 2$ e quinase. A análise de expressão corroborou com as mutações, com número extremamente reduzido de expressão nos pacientes com mutação tipo stop codon, níveis abaixo de $20 \%$ nos demais pacientes com os outros tipos de mutação, e apenas um paciente com nível de expressão de $60 \%$. Os dados obtidos reafirmam a diversidade clínica e molecular de XLA, onde observamos indivíduos com mesma mutação apresentando quadros distintos de manifestações, pacientes apresentando mutação tipo stop codon com quadro clínico estável e um paciente, que com uma simples troca de aminoácido, foi a óbito no transcorrer deste estudo. As diversidades moleculares e clínicas dos pacientes com agamaglobulinemia dificultam 0 desenvolvimento de uma terapia gênica para estes indivíduos.

Palavras-chave: imunodeficiência primária, agamaglobulinemia, imunidade humoral, linfócitos, mutação na Btk, células B. 


\begin{abstract}
Oliveira, RR. Study of the Btk (Bruton's Tyrosine Kinase) gene in patients with congenital agamaglobulinemia. [Thesis]. São Paulo: Interunidades em Biotecnologia USP/Instituto Butantan/IPT; 2008.
\end{abstract}

X-linked Agammaglobulinemia $(X L A)$ is a primary immunodeficiency considered a prototype defect of early B cell development. Approximately $85 \%$ of the patients with defects in early B-cell development have XLA, characterized by absent or decreased numbers of mature $B$ cells in peripheral blood and by markedly reduced levels of serum immunoglobulins $(\operatorname{lgG}<200 \mathrm{mg} / \mathrm{dL}, \lg M$ and $\lg A<2$ standard deviations for the age). Affected boys usually present an increased susceptibility to severe bacterial and enteroviral infections. XLA is caused by mutations in the gene for Bruton's agammaglobulinemia tyrosine kinase (BTK), with codes for a protein BTK expressed in hematopoietic cells. The btk gene is localized in the long arm of the $\mathrm{X}$ chromosome at q21.3-22 region. The BTK protein is a member of the Tec family of cytoplasmic tyrosine kinases and plays a vital, but diverse, modulation role in many cellular processes. About 10-15\% of the Agammaglobulinemia cases are not $X$-linked, are autossomal recessive, presenting characteristic phenotypes similar to the XLA, but absence of mutations in the gene btk. Thirty-three male patients were included in this study and analyzed for the presence of BTK mutations. The inclusion of the patients was based on three criteria, according to PAGID and ESID recommendations: absence or less than $2 \%$ of circulating $B$ cells; very low levels of serum IgG; and a history of recurrent bacterial infections.

In all the thirty-three patients the gene btk was studied by the screening mutation method (SSCP/HA). Possible mutations were characterized by direct sequencing and protein profile expression was analyzed by the real-time PCR technique. The recurrent infections founded in our patients were pneumonias, otitis, sinusitis, sepsis and diarrhea. Patients with a positive family history (parents or brothers) and with the same mutation had distinct clinical presentations. The mutations founded were of missense, nonssense, small deletions/insertions and splicing site alterations types affecting the $\mathrm{PH}, \mathrm{SH} 3, \mathrm{SH} 2$ and tyrosine kinase domains of btk gene. The expression levels correlated with the mutation types, since were extremely low in the patients with stop codon mutations, and below $20 \%$ in the patients with other mutations, and 
only one patient presented an expression level of $60 \%$. The data obtained reaffirm the clinical and molecular diversity of XLA, where we observe individuals with the same mutation presenting distinct patterns of manifestations, patients with stop codon mutations with stable clinical condition and a patient, who died during the development of this study, due to a simple amino acid exchange. The molecular and clinical diversity presented by patients with agammaglobulinemia raises objections to develop a gene therapy for these individuals.

Key words: primary immunodeficiency, B cells, lymphocyte, Btk mutation, agammaglobulinemia, humoral immunity. 


\section{Lista de Abreviaturas, Símbolos e Siglas}

\begin{tabular}{|c|c|}
\hline $\mathrm{BCR}$ & B cell receptor \\
\hline bp & base pair (pares de bases) \\
\hline BRAGID & Brazilian Group for Immunodeficiency \\
\hline BTK & Bruton's Tyrosine Kinase \\
\hline cDNA & DNA complementar \\
\hline CGD & Chronic granulomatous diseases \\
\hline CVID & Common variable immunodeficiency \\
\hline DEPC & Diethilpirocarbonato \\
\hline DGC & Doença Granulomatosa Crônica \\
\hline $\mathrm{dL}$ & Decílitro \\
\hline DNA & Ácido desoxirribonucleico \\
\hline DNase & Desoxirribonuclease \\
\hline dATP & 2'-deoxyadenosine 5'-triphosphate \\
\hline dCTP & 2'-deoxycytidine 5'-triphosphate \\
\hline dGTP & 2'-deoxyguanosine 5'-triphosphate \\
\hline dNTP & 2'-deoxinucleosideo 5'-trifosfato \\
\hline dTTP & 2'-deoxythymidine 5'-triphosphate \\
\hline dUTP & 2'-deoxyuridine 5'-triphosphate \\
\hline DP & Desvio padrão \\
\hline DTT & Dithiothreitol \\
\hline ESID & European Society for Immunodeficiency \\
\hline HIV & Human Immunodeficiency Virus \\
\hline IDP & Imunodeficiência Primária \\
\hline IDS & Imunodeficiência Secundária \\
\hline $\lg$ & Imunoglobulina \\
\hline $\lg A$ & Imunoglobulina A \\
\hline $\lg G$ & Imunoglobulina G \\
\hline $\lg M$ & Imunoglobulina M \\
\hline IVIG & Intravenous immunoglobulin \\
\hline
\end{tabular}

$\mathrm{Kb} \quad$ Kilobase

LAGID Latin American Group for Immunodeficiencies 


$\begin{array}{ll}\text { M } & \text { Molar } \\ \text { mg } & \text { Miligrama } \\ \text { mlg } & \text { Imunoglobulina de membrana } \\ \text { ml } & \text { mililitro } \\ \text { mRNA } & \text { RNA mensageiro } \\ \text { ng } & \text { nanograma } \\ \text { NK } & \text { Natural Killer } \\ \text { PAGID } & \text { Pan American Group for Immunodeficiencies } \\ \text { PCR } & \text { Polymerase chain reaction } \\ \text { PH } & \text { Pelckstrin Homology Domain } \\ \text { RAG } & \text { Recombination activating gene } \\ \text { RNA } & \text { Ácido ribonucléico } \\ \text { RNase } & \text { Ribonuclease } \\ \text { SCID } & \text { Síndrome da Imunodeficiência Combinada Severa } \\ \text { SD } & \text { Standard derivation } \\ \text { SH1 } & \text { Src homology 1 } \\ \text { SH2 } & \text { Src homology 2 } \\ \text { SH3 } & \text { Src homology 3 } \\ \text { T.A. } & \text { Temperatura ambiente } \\ \text { Taq } & \text { Thermus aquaticus } \\ \text { TdT } & \text { Desoxinucleotidiltransferase Terminal } \\ \text { TH-BTK } & \text { Tec Homology Domain-BTK } \\ \text { UDG } & \text { Uracil DNA glicolase } \\ \mu l & \text { microlitro } \\ \mu M & \text { micromolar } \\ \text { XLA } & \text { X-Linked Agammaglobulinemia } \\ \text { WHO } & \text { World Health Organization } \\ & \end{array}$




\section{Lista de Figuras}

Figura 1. Distribuição das Imunodeficiências Primárias entre 3321 pacientes notificados nos Registro do LAGID.

Figura 2. Esquema simplificado do desenvolvimento das células $B$ e as respectivas proteínas envolvidas neste processo.

Figura 3. Esquema das estruturas envolvidas no complexo pré-BCR (receptor das células pré-B) nas células B imaturas e do complexo BCR (receptor das células $B$ ) nas células $B$ maduras. Composição do receptor de célula pré- $B$ (pré-BCR) e complexos BCR

Figura 4. Modelo esquemático de BTK demonstrando diferentes domínios e interação molecular in vivo e in vitro.

Figura 5. Modelo esquemático das vias de sinalização de Btk

Figura 6. Figuras das alterações na corrida eletroforética encontradas nos pacientes e que foram submetidas ao seqüenciamento

Figura 7. Esquema da distribuição das mutações descritas neste estudo, ao longo dos domínios da proteína BTK.

Figura 8. Curva de dissociação (A) e de amplificação (B) do primer do gene controle $\beta$-actina.

Figura 9. Curva de dissociação (A) e de amplificação (B) com o primer do gene alvo Btk. 


\section{Lista de Gráficos}

Gráfico 1. Distribuição dos pacientes com idade de diagnóstico (ID) e com idade do primeiro sintoma (IS) ao longo da faixa etária.

Gráfico 2. Representação da média das idades do diagnóstico da IDP e das idades da primeira manifestação clínica dos pacientes expressa em meses....

Gráfico 3. Comparação da idade do $1^{\circ}$ sintoma (IS) e da idade do diagnóstico (ID) dos pacientes com história familiar $\left(\mathrm{c} / \mathrm{HF}_{+}\right)$e sem história familiar (c/HF-).

Gráfico 4. Comparação das idades do diagnóstico (ID) e das idades do primeiro sintoma (IS) entre os pacientes irmãos (IR) e de pacientes únicos não irmãos - (NIR).

Gráfico 5. Resumo das principais manifestações clínicas descritas no grupo dos pacientes que integram este estudo

Gráfico 6. Níveis da imunoglobulina $G$ dos pacientes no momento do diagnóstico e antes do inicio da terapia de reposição com imunoglobulina humana, comparados aos valores normais para a faixa etária.

Gráfico 7. Níveis da imunoglobulina $M$ no momento do diagnóstico dos pacientes e anteriores ao inicio da terapia de reposição com imunoglobulina humana.....

Gráfico 8. Níveis da imunoglobulina A no grupo dos pacientes no momento do diagnóstico e antes do inicio da terapia de reposição com imunoglobulina humana.

Gráfico 9. Valores das expressões do gene Btk expressos em percentual, após análise pelo método $2^{-\Delta \Delta C t}$ 


\section{Lista de Tabelas}

Tabela 1. Tipos de Agamaglobulinemias com Redução dos Linfócitos $B$ Periféricos e de todos os Isotipos de Imunoglobulinas; suas implicações celulares; alterações gênicas e cromossomos envolvidos.

Tabela 2. Relação estatísticas das idades do diagnóstico e da idade do primeiro sintoma entre os pacientes com história familiar positiva e história familiar negativa

Tabela 3. Relação estatísticas das idades do diagnóstico e das idades do primeiro sintoma entre os pacientes irmãos e de pacientes únicos (não irmãos) no grupo com história familiar positiva

Tabela 4. Relação das mutações encontradas em cada paciente e suas conseqüências.

Tabela 5. Dados da análise da expressão do gene Btk obtidas pela técnica real-time quantitativa relativa. 


\section{Sumário}

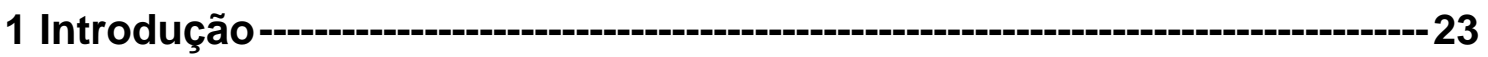

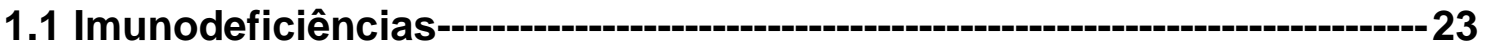

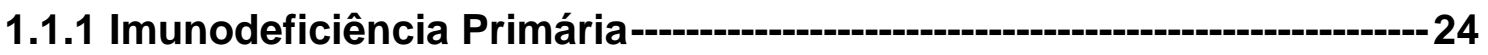

1.2 Imunodeficiência Humoral ---

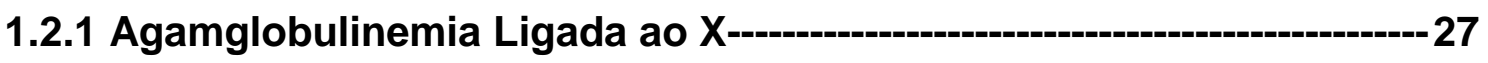

1.2.2 Agamaglobulinemia Autossômica Recessiva ---

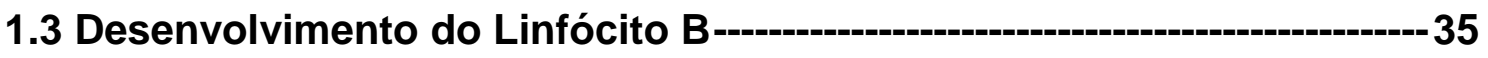

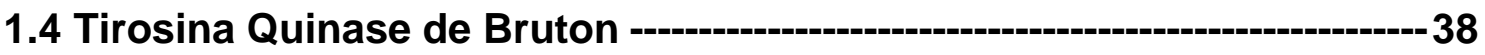

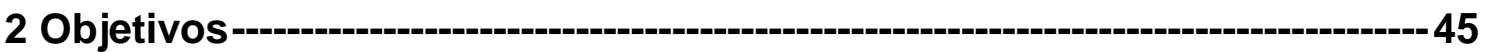

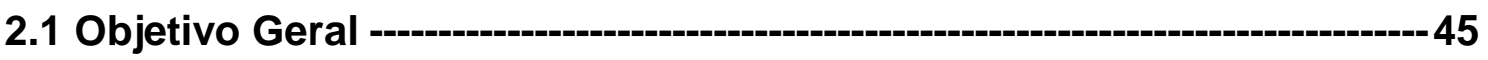

2.2 Objetivos Específicos - - 45

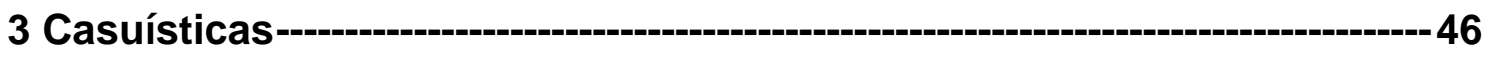

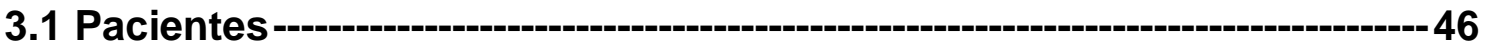

3.2 Critérios Clínicos-Laboratoriais de Inclusão de Pacientes-------------46

3.3 Anamnese dos Pacientes --

4 Materiais e Método -

4.1 Extração de DNA genômico a partir de sangue periférico--------------48

4.2 Determinação do DNA Genômico ---:- 48

4.3 Reação de Polimerase em Cadeia - PCR (Polymerase Chain

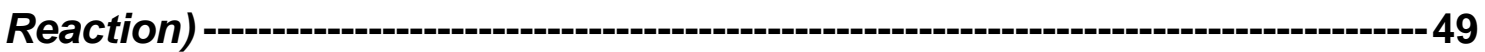

4.4 Triagem das amostras utilizando a técnica Polimorfismo conformacional de simples fita - Análise heteroduplex - "single-strand conformation polymorphisms/ heteroduplex analysis" (SSCP/HA) --------50

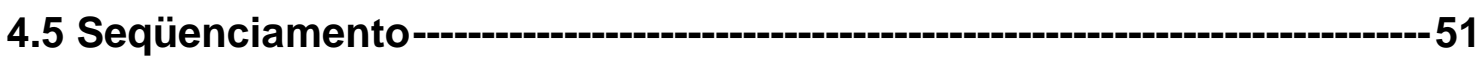

4.6 Extração de RNA total a partir de sangue periférico---------------52

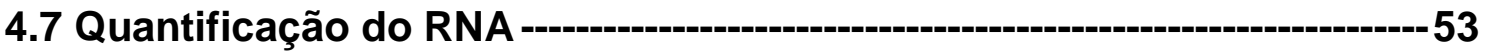

4.8 Tratamento do RNA com DNase I --_-54 


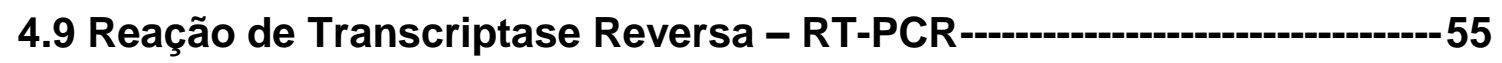

4.10 Reação Quantitativa Relativa em Tempo Real (Real-Time PCR)-------55

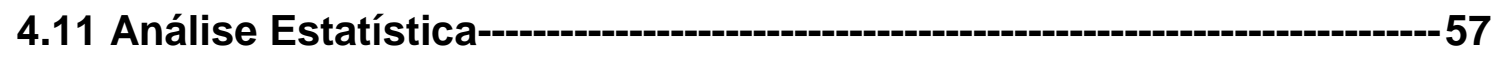

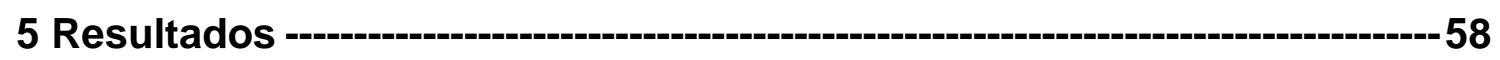

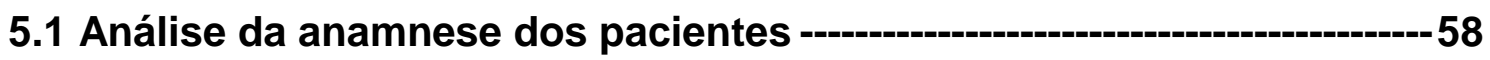

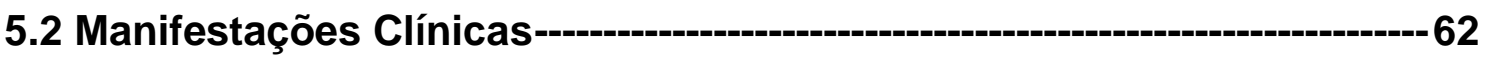

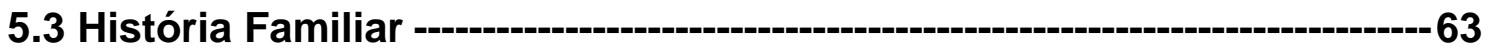

5.4 Níveis das Imunoglobulinas no Diagnóstico da IDP -----------------------64

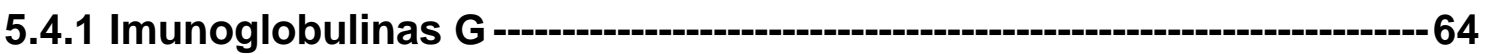

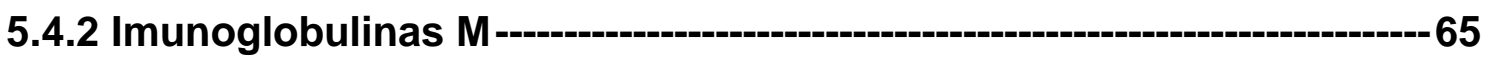

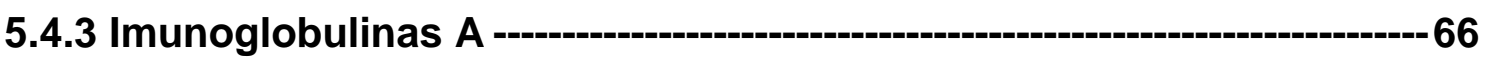

5.5 Concentração de Células B em Sangue Periférico ------------:------------67

5.6 Resultados da Análise dos Exons do Gene btk por SSCP/HÁ ----------68

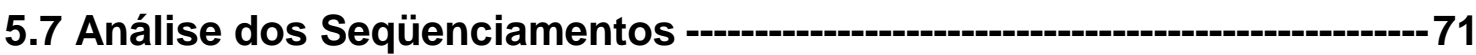

5.8 Análise da expressão do gene Btk através de Real-Time-PCR ---------73

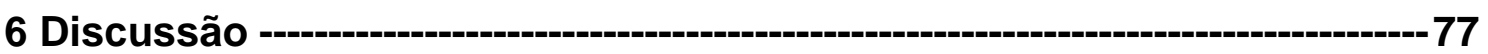

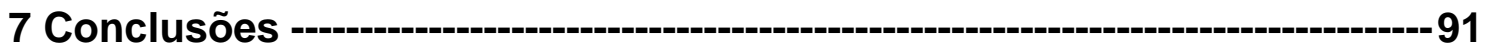

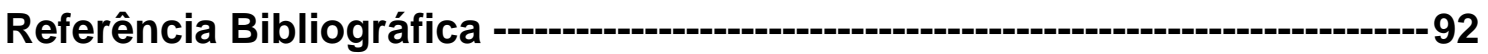

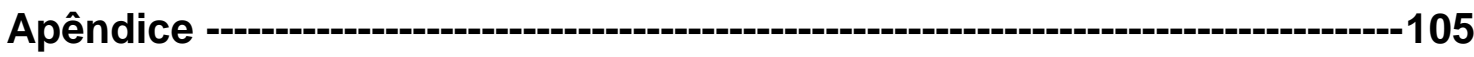

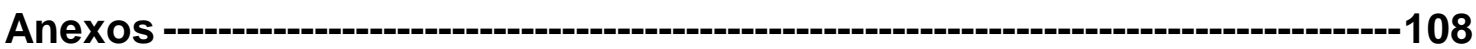




\section{Introdução}

\section{$1.1 \quad$ Imunodeficiências}

O sistema imunonológico é composto por células e moléculas com papéis especializados na defesa de nosso organismo contra a invasão de corpos estranhos. Existem dois tipos diferentes e fundamentais nas respostas a invasão de micróbios, as respostas inespecíficas (inatas) que ocorrem no mesmo instante em que o agente invasor é encontrado, e as respostas específicas (adquiridas) que melhoram a cada exposição repetida a um antígeno. A ativação dos linfócitos por um antígeno estranho é o evento central da resposta imunológica adaptativa. A complexidade das interações celulares que ocorre durante esta resposta requer micro-eventos especializados onde células relevantes, como as células apresentadoras de antígeno, colaboram eficientemente (Delves e Roitt, 2000a).

Os linfócitos B iniciam seu desenvolvimento no fígado fetal, em torno da 9o semana de gestação, e, ao longo da vida, este desenvolvimento ocorrerá na medula óssea. Estas células expressam uma diversidade de receptores antigênicos que são capazes de reconhecer uma variedade substancial de corpos estranhos ao organismo. Isto é possível, pois durante a sua maturação, os receptores específicos da superfície celular, após o contato com o antígeno, iniciam um programa seqüencial de expressão gênica direcionando a proliferação dos progenitores e iniciando o rearranjo gênico dos receptores antigênicos. Assim como os linfócitos $B$, os linfócitos $\mathrm{T}$ iniciam seu desenvolvimento num órgão linfóide primário, o Timo, e são submetidos a processos de seleção negativa e positiva. Sua maturação conta com enorme e diverso repertório de receptores para antígenos. As células T podem ser divididas em duas populações: Célula T que expressa o marcador CD4 e tem função de auxiliar (induzir) a resposta adaptativa; e, Células T expressando o marcador CD8 que tem atividades predominantemente citotóxicas (Roitt et al., 2003; Abbas et al., 2007).

Esta diversidade genética necessária para gerar uma resposta imune adaptativa eficiente resulta em amplo repertório celular dotado de memória, especificidade e capacidade de discriminação entre o próprio e o não próprio (Roitt et al., 2003; Abbas et al., 2007). 
Um defeito eventual neste complexo sistema poderá impedir o indivíduo de responder adequadamente contra infecções, podendo ter como conseqüência inúmeras doenças, chamadas de imunodeficiências, que podem ser herdadas e manifestar-se no início da vida do indivíduo ou podem ser adquiridas ao longo da vida. As Imunodeficiências podem ser classificadas em dois grupos:

Primárias ou Congênitas - defeitos genéticos que resultam em um aumento da suscetibilidade a infecções, com início precoce na infância, porém detectada clinicamente mais tardiamente na vida.

- Secundárias ou Adquiridas - Surgem em conseqüência de distúrbios nutricionais, doenças metabólicas, o uso de drogas imunossupressoras, transplantes de órgãos e infecção pelo vírus da imunodeficiência adquirida (HIV), entre outras causas.

\subsubsection{Imunodeficiência Primária}

As Imunodeficiências Primárias (IDP) representam um grupo amplo de doenças geneticamente heterogêneas que afetam componentes distintos do sistema imunológico inato e adaptativo. Estes defeitos resultam em um aumento da suscetibilidade a infecções recorrentes e persistentes, por diferentes agentes patológicos, sendo este aumento da suscetibilidade a infecções a característica da quase totalidade das IDP. Pacientes com IDP apresentam uma variedade ampla de sintomas clínicos que vão desde uma maior susceptibilidade a infecções, doenças alérgicas, autoimunidade, doenças inflamatórias, como também uma maior susceptibilidade a neoplasias. Assim sendo, as IDP caracterizam-se por defeitos qualitativos e/ou quantitativos em um ou mais sistemas responsáveis pela proteção do organismo [International Union of Immunological Societies (IUIS), 1999; Rosen et al., 1995; Geha et al., 2007].

Os principais exemplos da relação do defeito no sistema imunológico e a etiologia de uma infecção são: infecções por bactérias piogênicas em pacientes com deficiência de anticorpos; infecções oportunistas por fungos e vírus nos pacientes com imunodeficiência grave combinada (SCID); infecções com Neisseria meningitidis em pacientes com defeitos no sistema complemento; infecções por 
estafilococos nos pacientes com neutropenia e a susceptibilidade a micobactérias e salmonelas em pacientes com deficiência no eixo Interleucina-12-Interferon gama (IL-12-IFN-y) (Carneiro-Sampaio e Coutinho, 2007).

O reconhecimento das IDP tem cerca de 50 anos, porém ainda são consideradas como grupo de doenças novas na medicina. Em 1970, a Organização Mundial de Saúde (WHO) criou um comitê de especialistas para definir e classificar estas doenças, onde, e neste mesmo ano, foram descritas 14 diferentes IDP (Fundenberg et al., 1970; Notarangelo, 2004). A partir deste comitê criou-se a União Internacional de Sociedades de Imunologia (IUIS) que passou a definir a classificação destas afecções médicas, que contam hoje com mais de 120 IDP descritas, com defeitos genéticos identificados em sua quase totalidade (Geha et al., 2007; Notarangelo, 2004; Notarangelo et al., 2006).

Durante a última década, avanços significativos têm sido feitos no diagnóstico e manejo destas doenças, reduzindo a morbidade e mortalidade deste grupo. No entanto, estudos epidemiológicos têm demonstrado uma ampla variação de acordo com a etnia e área geográfica na prevalência e nos padrões das IDP. Devido à falta de especificidade dos sinais e sintomas das IDP, como conseqüências pacientes vão a óbito ou permanecem sem tratamento por vários anos. Nos países desenvolvidos a criação de registros internacionais para estimar a prevalência, incidência e padrões das IDPs é uma realidade. Entretanto as informações epidemiológicas destas doenças nos países em desenvolvimento são dificultadas por recursos limitados para diagnóstico e tratamento destas doenças (Leiva et al., 2007).

Em 1993, formou-se um grupo cooperativo de imunologistas clínicos oriundos de vários países latino-americanos (LAGID - Latin American Group for Immunodeficiencies), cujo principal objetivo era o de melhorar as condições para diagnóstico das IDP nos países Latino-Americanos (Zelasko et al., 1998). Na sua formação os países que integravam o LAGID eram Argentina, Brasil, Chile e Colômbia e contavam com 1.428 pacientes notificados. Atualmente fazem parte deste grupo 14 países, refletindo um aumento no reconhecimento e notificação das IDP nestes países. Desde a sua primeira publicação (Carneiro-Sampaio, 1999; Zelasko, et al., 1998) até o momento observou-se um aumento nítido de notificação das IDPs, sendo as mais freqüentes as deficiências de anticorpos (53,2\%), com a deficiência de IgA o fenótipo com maior número de casos registrados (Figura 1). 
Dentre as IDP com maior aumento no número de notificações destacam-se três delas: Agamaglobulinemia Congênita (XLA); Doença Granulomatosa Crônica (CGD) e Síndrome da Imunodeficiência Grave Combinada (SCID) (Leiva et al., 2007).

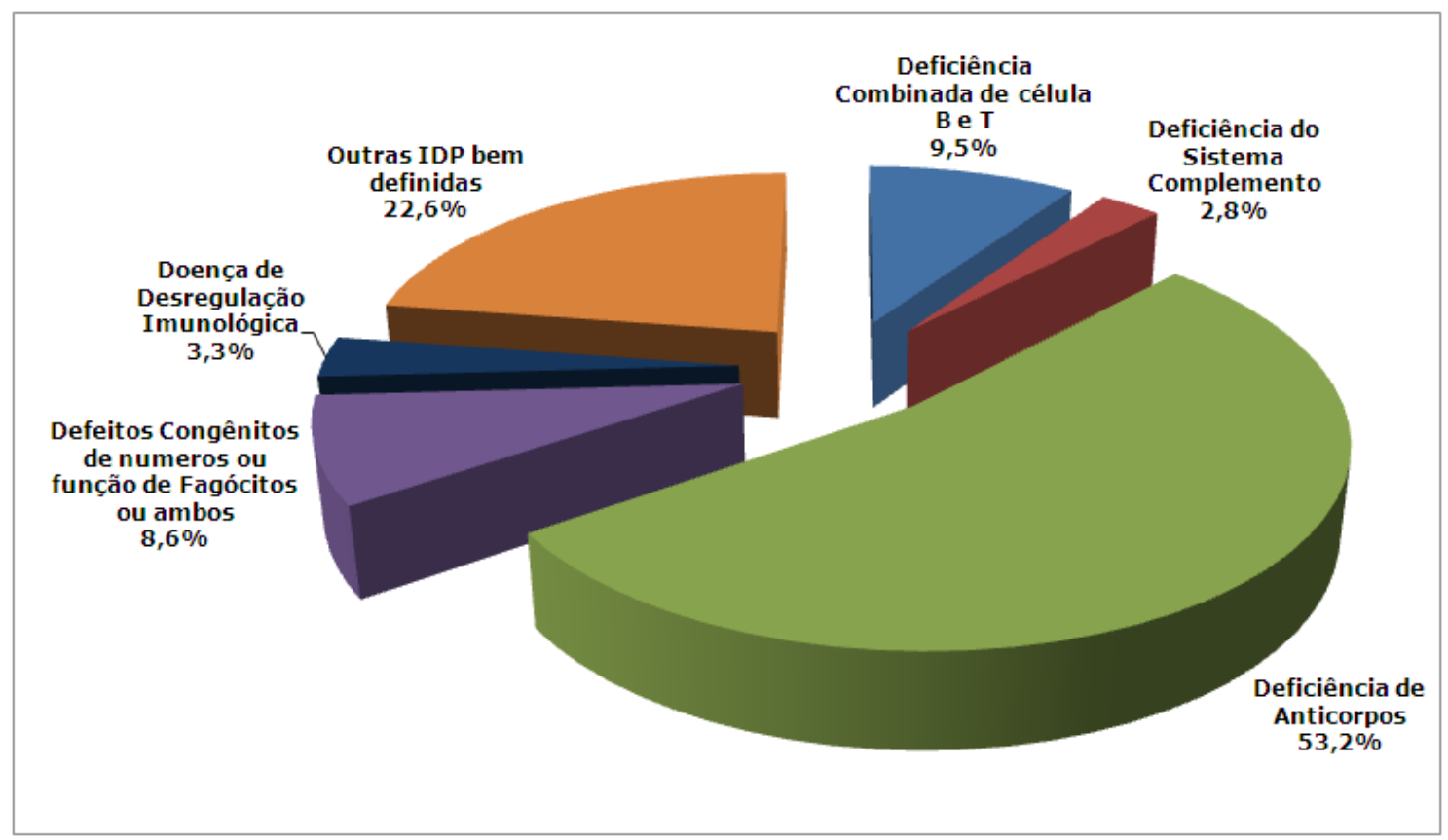

Figura 1. Distribuição das Imunodeficiências Primárias entre 3.321 pacientes notificados nos Registros do LAGID (Leiva et al., 2007).

Claramente, as IDP são doenças incomuns e desafiadoras para cientistas e clínicos, pois elas representam modelos naturais de estudo da imunopatologia, que anteriormente estava baseada em modelos animais, pois podem manifestar uma ampla diversidade de sintomas. Os avanços nas pesquisas das IDP, nas últimas décadas, têm esclarecido os mecanismos básicos do desenvolvimento e da função do sistema imunológico e têm permitido o reconhecimento de uma série de novos defeitos e formas das IDP e a caracterização de suas bases moleculares. Os defeitos gênicos das IDP afetam a expressão e função de proteínas envolvidas no amplo processo biológico, assim como no desenvolvimento imunológico, nas funções de células efetoras, na cascata de sinalização e a na manutenção da homeostase do sistema imunológico (Kumar et al., 2006; Maròdi e Notarangelo, 2007).

\subsection{Imunodeficiência Humoral}


As IDP que resultam em deficiência humoral, ou de anticorpos, são as mais freqüentes no grupo das IDP. Estas deficiências envolvem defeitos nas proteínas que estão envolvidas no processo de maturação do linfócito $B$, com conseqüente paralisação do desenvolvimento destes linfócitos (Kumar et al., 2006). Dentre os principais agentes patológicos que acometem os pacientes com deficiência de anticorpos estão Streptococcus pneumoniae, Haemophilus influenzae, Staphylococcus aureus, Pseudomonas aeruginosa, Campylobacter fetus e Neisseria meningitidis; além das Enteroviroses e infecções por protozoários, sendo a Giardia lamblia de maior incidência (Bonilla e Geha, 2006; Subauste, 2006).

Dentre as deficiências de anticorpos temos as Agamaglobulinemias que compreendem afecções com herança recessiva ligada ao $X$ ou autossômica recessiva. Na tabela 1 estão descritas as principais agamaglobulinemias, gene envolvido, alterações funcionais e localização cromossômica.

Tabela 1. Tipos de agamaglobulinemias com Redução dos Linfócitos B Periféricos e de todos os Isotipos de Imunoglobulinas; suas implicações celulares; alterações gênicas e cromossomos envolvidos:

\begin{tabular}{l|l|lc|l} 
Herança & Gene & Funções Celulares & Cromossomo \\
\hline Ligada ao X (XLA) & btk & $\begin{array}{l}\text { Atua no processo de desenvolvimento das } \\
\text { células B. }\end{array}$ & Xq21.3-22 \\
\hline
\end{tabular}

\section{Autossômicas Recessivas}

\begin{tabular}{|c|c|c|c|}
\hline $\lg \alpha$ & $m b-1$ & $\begin{array}{l}\text { Heterodímeros } \lg \alpha / \lg \beta \text { atuam como transdutores } \\
\text { de sinal na formação do complexo BCR. }\end{array}$ & $19 q 13.2$ \\
\hline Cadeia pesada $\mu$ & igmh & $\begin{array}{l}\text { Atua na maturação do estágio das Células pré-B } \\
\text { a Células B maduras. }\end{array}$ & 14q32.33 \\
\hline Cadeia $\lambda 5 / 14.1$ & $\lambda 5$-like & $\begin{array}{l}\text { Componente da cadeia leve substituta (surrogate } \\
\text { light chain). }\end{array}$ & $22 q 11.23$ \\
\hline BLNK & blnk & $\begin{array}{l}\text { Proteína adaptadora coordena sinalização de } \\
\text { pré-BCR para BCR via fosforilação do resíduo de } \\
\text { tirosina. }\end{array}$ & $10 q 23.22$ \\
\hline $\lg \beta$ & B29 & $\begin{array}{l}\text { Heterodímeros } \lg \alpha / \lg \beta \text { atuam como transdução } \\
\text { de sinal na formação do complexo BCR. }\end{array}$ & 17q23 \\
\hline
\end{tabular}

Fonte: Tabela adaptada de Geha et al., 2007.

\subsubsection{Agamaglobulinemia ligada ao $X$}


Dentre as Agamaglobulinemias, a forma ligada ao $\mathrm{X}(\mathrm{XLA})$ foi a primeira imunodeficiência primária a ser identificada (Bruton, 1952) constituindo o maior grupo, sendo responsável por aproximadamente $85 \%$ dos casos de agamaglobulinemia. XLA caracteriza-se por níveis de imunoglobulina séricos muito baixos ( $\lg G<200 \mathrm{mg} / \mathrm{dL}$, $\lg M$ e $\lg A<2$ Desvio Padrão [SD] para faixa etária), freqüentemente associados à redução acentuada de células $B$ maduras periféricas, em conseqüência de uma interrupção na maturação da linhagem destas células, no estágio entre pró-B e pré-B na medula óssea.

O Grupo Pan-Americano de Imunodeficiência (PAGID) estabeleceu critérios diagnósticos para algumas IDP, dentre as quais a XLA (Conley et al., 1999). Os critérios são:

1. Definitivo: menino com menos de $2 \%$ de células CD19+ (linfócitos $B$ ) e, pelo menos, um dos seguintes critérios:

a) Mutação no gene btk;

b) Ausência de mRNA para Btk em análise de Northern blot de neutrófilos e monócitos;

c) Ausência da proteína Btk em monócitos ou plaquetas;

d) Primos maternos, tios ou sobrinhos com menos de $2 \%$ de células CD19+ (linfócito B).

2. Provável: menino com menos de $2 \%$ de células CD19+ (linfócitos B) e com todos os seguintes critérios:

a) Início de infecções bacterianas de repetição nos primeiros 5 anos de vida;

b) Níveis de lgG, IgA e IgM muito reduzidos (menos que 2 desvios-padrão (SD) para idade);

c) Ausência de resposta pós-vacinal e de isohemaglutininas;

d) Outras causas de hipogamaglobulinemia excluídas.

3. Possível: menino com menos de $2 \%$ de células CD19+ (linfócitos B) no quais outras causas de hipogamaglobulinemia tenham sido excluídas, e no mínimo um dos critérios:

a) Início de infecções bacterianas de repetição nos primeiros 5 anos de vida;

b) Níveis de lgG, IgA e lgM muito reduzidos (menos que 2 SD para idade);

c) Ausência de isohemaglutininas. 
A Agamaglobulinemia Congênita foi descrita em 1952 por Bruton, que relatou o caso de um menino de oito anos de idade que apresentava infecções de repetição, incluindo vários episódios de sepse causadas por diferentes sorotipos de pneumococo. A análise do soro por intermédio da eletroforese de proteínas revelou a ausência da fração gama. Foi feita, então, associação da ausência da fração gama com as infecções de repetição. Esta criança descrita por Bruton foi tratada mensalmente com doses subcutâneas de imunoglobulinas (Bruton, 1952; Conley et al., 2005).

Além do nível muito baixo de todas as classes de imunoglobulinas, demonstrada por Bruton, na década de 70, demonstrou-se que os portadores desta doença não apresentavam linfócito $B$ na circulação periférica, nem nos órgãos linfóides, demonstrando-se posteriormente a existência de uma interrupção da maturação da linhagem B, no estágio compreendido entre pró-B e pré-B (Siegal et al., 1971; Geha et al., 1973; Pearl et al., 1978).

Em 1993, esta doença foi associada, simultaneamente por dois diferentes grupos de pesquisadores, um na França e outro nos EUA, a um defeito no gene codificador de uma tirosina quinase presente em linfócitos $B$, denominado btk. $A$ expressão da Btk é restrita às células hematopoiéticas, sendo encontrada ao longo da diferenciação da linhagem B desde as células precursoras CD34+ até os linfócitos $B$ maduros, sendo regulados negativamente nos plasmócitos secretores de anticorpos. A expressão de Btk também é detectada em monócitos, células da linhagem mielóide, precursores de eritrócitos e megacariócitos. Não existem evidências de sua expressão na linhagem $\mathrm{T}$ e nem em células natural killer (NK) (Tsukada et al., 1993; Vetrie et al., 1993; Gaspar et al., 2000).

A XLA é considerada o protótipo das imunodeficiências primárias e dos defeitos no desenvolvimento de células $B$ (Usui et al., 2001). Sua freqüência está estimada em 1:200.000. A maior susceptibilidade às infecções de repetição representa a principal manifestação clínica destes pacientes, sendo as infecções causadas por bactérias extracelulares (Black et al., 2005) e também por enterovirus (Lopez-Granados, 2005).

Devido ao quadro clínico destes pacientes ser caracterizado por queixas comuns na clínica pediátrica, o diagnóstico geralmente é feito após o $1^{\circ}$ ano de vida ou mais tardiamente (Black et al., 2005; Conley e Howard, 2002). 
Uma importante característica clínica destes pacientes é o fato deles terem ausência ou tamanho reduzido das tonsilas e linfonodos (Conley e Howard, 2002), com órgãos linfóides, tais como linfonodos e apêndices, sem centros germinativos e folículos. Na lâmina própria do intestino, os plasmócitos estão ausentes, ao contrário dos pacientes com outras IDP (Grumach, 2001).

As mutações encontradas no gene btk pelos diferentes grupos de estudo são muito heterogêneas, geralmente particulares para cada família, com predomínio das localizadas no domínio quinase (Rodriguez et al., 2001). Até o momento, foram descritas 620 mutações únicas para este gene. Um terço das mutações é do tipo "missense" e estas são encontradas principalmente no domínio quinase do gene, embora também tenham sido identificadas em todos os outros domínios, com exceção do SH3. Também foram identificados "stop codons" precoces, deleções e inserções ao longo de toda a extensão do gene. Embora a maior parte das mutações tenha sido encontrada nos exons, $12 \%$ das mutações foram identificadas em sítios de "splicing". Somente uma mutação foi encontrada na região promotora do gene, e esta mutação resulta em alterações significantes do gene btk. Além das mutações, também foram detectadas inversões, duplicações e inserções retrovirais (Väliaho et al., 2006).

$A$ doença de Bruton (XLA) é relacionada à herança ligada ao $X$ recessiva com penetrância completa. Somente homens são afetados e todos, com raras exceções, são sintomáticos (Conley et al., 2005). No entanto, Takada e colaboradores (2004) descreveram uma criança do sexo feminino com todos os sintomas para XLA. Esta criança era filha de um pai com diagnóstico confirmado para XLA. Estudos de inativação do cromossomo $X$ nesta paciente demonstraram presença de forma não usual de inativação do cromossomo $X$. $O$ cromossomo $X$ ativo em mulheres portadoras de XLA sempre será o cromossomo que possui o alelo normal, entretanto, os autores verificaram que no caso da paciente feminina com XLA a inativação ocorreu, por mecanismo ainda desconhecido, no cromossomo de origem materna ficando ativo o cromossomo que contém o alelo com o gene btk mutado herdado do pai. Esta inativação não usual foi observada em todas as suas linhagens celulares.

Um estudo foi conduzido por Conley e Howard (2002) para se determinar os achado clínicos para o diagnóstico de XLA em pacientes após a década de 1990. Este estudo demonstrou que a média de idade do diagnóstico nestes pacientes foi 
de 35 meses e que, muitos deles, foram reconhecidos como imunodeficientes após internação por graves infecções. Apesar de se achar que os pacientes com XLA pudessem contar com proteção conferida pelos anticorpos adquiridos da mãe, tem se relatado o diagnóstico em crianças com menos de um ano de vida. Um padrão de manifestações clínicas tem sido descrito para pacientes com Pioderma gangrenoso; abcesso periretal; celulite ou impetigo associado com sepse por pseudomonas ou estafilococos e neutropenia. Tanto a sepse por pseudomonas ou estafilococos quanto a neutropenia são achados descritos em pacientes com diagnóstico mais tardio. $\mathrm{Na}$ quase totalidade dos pacientes, relatou-se história de otites recorrentes e/ou sinusites na época do diagnóstico. As infecções nestes pacientes eram muito diversificadas, variando desde pneumonias e artrites até meningite. Infecções de menor severidade, incluindo diarréia e conjuntivite, eram comuns em pacientes com XLA. Quando o diagnóstico é realizado com mais de 40 meses de idade observa-se uma história de múltiplas hospitalizações por infecções, enquanto outros pacientes evoluem relativamente assintomáticos até a idade escolar.

Embora a maioria dos pacientes seja diagnosticada como sendo portadores de imunodeficiência, em média até os seus cinco anos de idade, têm sido descritos casos raros de adultos que são diagnosticados com hipogamaglobulinemia, além de drástica redução de células $B$ e mutação na Btk. Estes indivíduos relatam freqüentemente história de infecções recorrentes ou sinusites persistentes, porém suas infecções não são graves o bastante para sugerirem o diagnóstico de imunodeficiência. Alguns destes homens continuam a conduzir suas vidas normalmente, mesmo na ausência de reposição com gamaglobulina (Kornfeld et al., 1996; Conley e Howard, 2002).

A despeito da grande quantidade de mutações descritas e dos inúmeros dados disponíveis sobre o fenótipo dos pacientes, ainda não se estabeleceu uma correlação definitiva entre o genótipo e o fenótipo nos casos de agamaglobulinemia.

Um estudo baseado na análise de questionário clínico e imunológico foi conduzido envolvendo uma casuística de 73 pacientes do sexo masculino com um diagnóstico definitivo de XLA baseado na análise de seqüências de DNA. Os dados demonstraram que a média de idade do diagnóstico foi de 3,5 anos, as infecções respiratórias foram as mais incidentes, com as doenças crônicas pulmonares presentes em 23 destes pacientes. Diferentes tipos de mutações foram encontrados em 63 destes pacientes: 55,6\% foram mutações missense; $14,3 \%$ mutações do tipo 
stop codon prematuro; $15,9 \%$ pequenas deleções; $6,3 \%$ pequenas inserções e $7,9 \%$ foram mutações localizadas em sítio de splicing. Porém, a análise de todos os dados não permitiu ao grupo de pesquisadores estabelecerem uma relação entre a clínica destes pacientes com as respectivas mutações encontradas (Plebani et al., 2002).

López-Granados e colaboradores (2005) estudaram, em 54 pacientes, as conseqüências das mutações e o nível de expressão da proteína e correlacionaram com os dados clínicos. Este grupo classificou as mutações de acordo com o tipo de comprometimento na produção da proteína BTK em relação às manifestações clínicas. Para este estudo, o grupo classificou como mutações graves àquelas relacionadas a manifestações clássicas de XLA: infecções de repetição desde o primeiro ano de vida; níveis reduzidos de células B - <1\%; lgG abaixo de $200 \mathrm{mg} / \mathrm{dl}$ e níveis de lgA e lgM inferiores a $20 \mathrm{mg} / \mathrm{dl}$. Porém, a correlação genotípica e fenotípica dos pacientes com XLA não pode ser concluída devido às discrepâncias entre a gravidade das mutações e as manifestações clínicas sugerindo que outros fatores, genéticos e ambientais, influenciam significativamente na apresentação da doença e sua evolução.

Broides e colaboradores (2006) estudaram um grupo de 110 pacientes quanto à idade do diagnóstico destes pacientes, a mutação detectada, os níveis de IgM e o percentual de células $B$ no sangue periférico, e relacionou estes fatores entre si. Verificaram que a correlação entre uma mutação específica e a gravidade da doença não é suficientemente forte para ser usada como fator preditivo do curso clínico de um dado paciente. No entanto, este estudo indicou que algumas mutações no gene da btk, particularmente as que permitem a produção de níveis médios da proteína em monócitos, estão associadas à forma mais branda da doença.

Além da diversidade clínica que os pacientes com agamaglobulinemia apresentam, a literatura vem descrevendo outras manifestações associadas a XLA. Em 1999, Pereira e Silva descrevem o caso de um paciente com agamaglobulinemia Congênita que apresentou o quadro de monoartrite asséptica crônica, sendo esta associação incomum. Um paciente de 54 anos, caracterizado em termos moleculares como XLA contraiu o vírus da poliomielite aos cinco anos de idade e sobreviveu, apresentando morbidade residual relativamente branda.

Outros casos têm sido relatados, como de um menino de 5 anos de idade com agamaglobulinemia que apresentou sintomas de doença neurológica crônica, porém os autores relatam que nenhum patógeno foi isolado, sugerindo que o 
episódio pode ter sido causado por autoimunidade mediada por células CD8+, devido a infiltrados desta população celular na medula óssea (Shiroma et al., 2004).

Arai e colaboradores (2007) relataram bacteremia por Campylobacter coli em paciente adulto com XLA, posteriormente acompanhada de artrite reativa durante a terapia com imunoglobulina intravenosa.

Lin e colaboradores (2006) descrevem o caso de um paciente que aos 10 anos foi diagnosticado com CVID (7\% de células B circulantes) e, após 10 anos, desenvolveu piodermatite recorrente e hipogamagaglobulinemia $(0,4 \%$ de células $B$ circulantes), com testes moleculares que confirmaram se tratar de XLA. E o primeiro caso de associação entre XLA e dermatofibrosarcoma protuberante, uma doença monoclonal cutânea rara, foi descrita por Yong e colaboradores no ano de 2007.

\subsubsection{Agamaglobulinemia Autossômica Recessiva}

Cerca de 10 a 15\% dos casos de agamaglobulinemia não estão ligadas ao X, são autossômicas recessivas, apresentando características fenotípicas semelhantes a XLA, porém com ausência de mutações no gene btk, e 5\% a 10\% destes casos de agamaglobulinemia são doenças não ligadas a erro genético (Conley et al., 1992; Conley et al., 2005). Nessa categoria, foram descritas, até o momento, mutações na cadeia pesada $\mu$, onde se encontram os maiores números de mutações descritas, cadeia leve $\lambda 5$, Ig $\alpha$ e BLNK, os quais estão localizados nas regiões dos cromossomos 14q32.3, 22q11.22, 14q13.2 e 10q23.22, respectivamente. Essas mutações afetam os componentes do receptor das células $B(B C R)$, além de atuarem na transdução do sinal para BCR, afetando a maturação das células $B$ nos estágios entre pró-B e pré-B, à semelhança do que ocorre nos casos de mutações do btk (Minegishi et al., 1999a; Minegishi et al., 1999b; Lopez et al., 2002; Ferrari et al., 2007).

Desta forma, os afetados tanto pela XLA, como pelas formas autossômicas recessivas apresentam ausência ou valores muito baixos $(<1 \%)$ de linfócitos $B$ no sangue periférico. Os achados clínicos em pacientes com esta forma rara de agamaglobulinemia são indistinguíveis dos pacientes com XLA. Em algumas famílias de afetados existe o relato de consangüinidade entre os pais e em outras, os pais ou avós eram de comunidades isoladas (Yel et al., 1996; Lopez et al., 2002; Conley et 
al., 2005). Infecções cutâneas, neutropenias e sepses por pseudomonas e estafilococos têm sido relatados em pacientes com mutações na cadeia pesada $\mu$, na Iga e no gene blnk (Minegishi et al., 1999c; Lopez et al., 2002).

O receptor de células B é um complexo multimolecular, formado pela imunoglobulina da membrana $(\mathrm{mlg})$ e pelo heterodímero associado $\lg \alpha$ (CD79a) e $\lg \beta$ (CD79b) (Reth e Wienands, 1997). Estas moléculas funcionam como subunidades de sinalização, sabendo-se que somente um BCR completo é capaz de transduzir adequadamente sinais ao interior dos linfócitos B (Reth e Wienands, 1997; Kelly e Chan, 2000) (Figura 2).

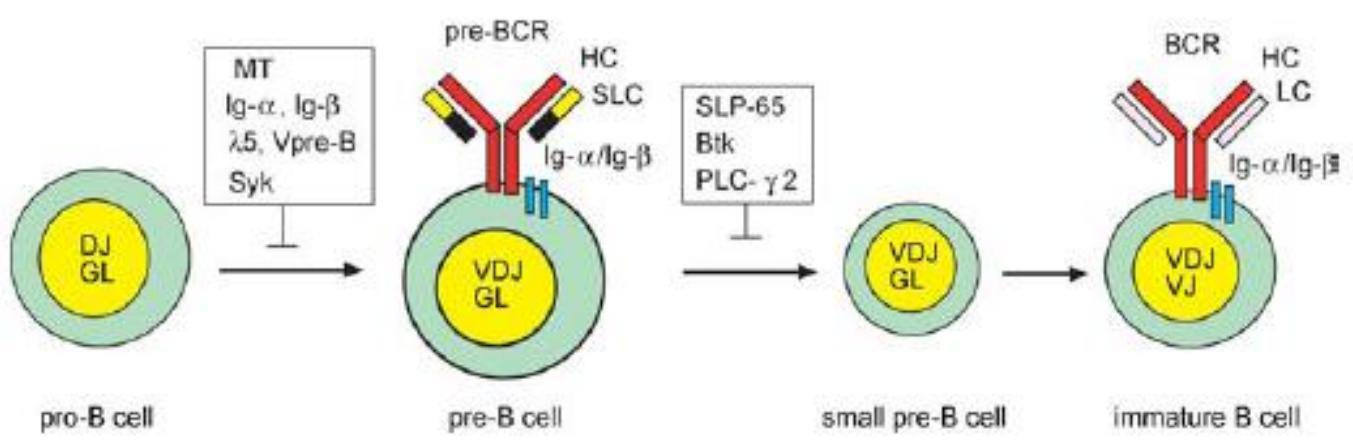

Figura 2. Esquema simplificado do desenvolvimento das células $B$ e as respectivas proteínas envolvidas neste processo. De forma simplificada, o rearranjo do gene da cadeia pesada nas células pró-B resulta na expressão do receptor das células pré-B (pré-BCR) e, conseqüentemente, a expressão das células pré-B. Rearranjo produtivo das cadeias leves nas pequenas células pré-B levam a expressão do receptor das células $B(B C R)$ nas células B imaturas (Jumaa et al., 2005).

Já foram descritos alguns casos de agamaglobulinemia associados a mutações no gene que codifica a $\lg \alpha(C D 79 a)$, o que leva a não expressão desta estrutura que constitui um dos componentes do BCR (Grunebaum, 2001). Também existem relatos de defeitos na cadeia pesada $\mu$ localizado na região do cromossomo 14q32.3, provocando desenvolvimento anormal de células B (Granados et al., 2002) e também nas cadeias leves da imunoglobulina em crianças com agamaglobulinemia (Milili et al., 2002). Minegishi e colaboradores (1999c) descrevem a substituição de bases A-T no intron 1 do gene blnk localizado no cromossomo 10q23.22, alterando a expressão de uma proteína adaptadora BLNK, da qual o receptor de células $B$ é dependente para a fosforilação. A freqüência de mutação nestes genes é rara e heterogênea. 
Defeitos da cadeia pesada $\mu$ contam com aproximadamente $5 \%$ dos casos de agamaglobulinemia congênita. Mutações descritas em 16 famílias têm demonstrado alguns contrastes interessantes com os defeitos relatados na Btk. Grandes deleções de até $38 \mathrm{~Kb}$ de extensão são responsáveis por $3,5 \%$ do total das mutações descritas para Btk. Das 13 mutações descritas para o gene da cadeia pesada $\mu, 6$ são extensas deleções superiores a $40 \mathrm{~Kb}$ de extensão, algumas deleções chegam a 350Kb de extensão. Outras mutações são: duas de substituição de aminoácido, três são mutações de frameshift, uma de stop codon prematuro e a outra de substituição de uma simples base na região de reconhecimento de sítio de splicing (Yel et al., 1996; Lopez et al., 2002; Milili et al., 2002).

Os avanços da biologia molecular e da análise genômica têm facilitado a localização dos genes relacionados a essas deficiências e identificação das mutações associadas, ajudando no estabelecimento do diagnóstico precoce e mais preciso dessas doenças. Porém com a complexidade do locus da cadeia pesada $\mu \mathrm{e}$ a raridade das outras formas autossômicas recessivas de agamaglobulinemia, será pouco provável que a terapia gênica seja uma opção para estes pacientes (Conley et al., 2005).

\subsection{Desenvolvimento do Linfócito B}

A resposta imune humoral, mediada por anticorpos, é resultado de uma série de interações moleculares e celulares que ocorrem de acordo com seqüência ordenada entre uma célula $B$ e uma variedade de outras células do sistema imunológico (Przylepa et al., 1998).

O desenvolvimento das células $B$ é caracterizado por etapas ordenadas do rearranjo gênico das cadeias leves $(L)$ e pesadas $(H)$ das imunoglobulinas, criando um repertório diversificado de células $B$. Este processo ocorre na vida fetal durante o desenvolvimento embrionário e subseqüentemente é mantido na medula óssea durante a fase adulta. Os pontos de verificação ao longo deste desenvolvimento asseguram que somente as células que expressam o rearranjo gênico funcional prossigam na diferenciação.

Os linfócitos B se desenvolvem a partir de progenitores não diferenciados ou células-tronco que residem na medula óssea e são provavelmente descendentes 
das células-tronco hematopoiéticas pluripotentes. $O$ desenvolvimento envolve a aquisição sucessiva de propriedades que são essenciais para a função da célula $B$ madura, concomitantemente com a perda das propriedades inerentes às células no estágio de imaturidade (Akashi et al., 1999).

$O$ desenvolvimento das células $B$ é dependente das células do estroma não linfóide da medula óssea. Estas células formam contatos de adesão específica com as células da linhagem $B$ em desenvolvimento por interações entre moléculas de adesão celular e seus ligantes, e posteriormente fornecem fatores de crescimento que controlam a diferenciação e a proliferação de linfócitos (Jacobsen et al., 1996).

As células $B$ mais precoces são conhecidas como células pró-B. Estas não produzem imunoglobulinas, mas são comprometidas com as linhagens de células $B$. Distinguem-se de outras células imaturas pela expressão de receptores de superfície, como CD19 e CD10 (Allman e Hardy, 1999). Neste estágio, as células B podem ser divididas em precoces e tardias dependendo da expressão da desoxinucleotidiltransferase terminal (TdT), uma enzima intracelular expressa unicamente durante o rearranjo do gene da cadeia pesada $V_{H}$ (Allman e Hardy, 1999).

A recombinação dos genes da cadeia pesada de imunoglobulina começa nas células pró-B precoces com a junção do segmento gênico $D$ ao segmento gênico $J_{H}$. Neste ponto, a célula é classificada de pró-B tardia, na qual é dada continuidade ao rearranjo gênico quando um segmento $V_{H}$ sofre rearranjo com um segmento $D J_{H}$. Ao longo de todo este estágio, as células expressam as moléculas CD43, CD19, e as proteínas RAG-1 (recombination activating gene-1) e RAG-2 (recombination activating gene-2). A junção produtiva de $V D J_{H}$ leva à expressão de uma cadeia pesada intacta $\mu$, que é o marco do próximo estágio principal de desenvolvimento (Hardy et al., 1991; Hardy e Hayakawa, 2001).

No estágio de pré-B, a célula pode ser dividida em grande (com intensa atividade mitótica) e pequena (em repouso no citoplasma). As cadeias pesadas $\mu$ das Ig são expressas no citoplasma, e possivelmente em pequenas quantidades na superfície da célula, tanto em células pré-B grandes, como pequenas. A interação da cadeia pesada $\mu$, com duas proteínas Vpré-B e $\lambda 5$, também chamadas de "surrogate light chains", produzidas nas células pró- $\mathrm{B}$, e duas cadeias acessórias invariáveis Ig $\alpha$ e $\lg \beta$ formam o complexo do receptor da célula pré-B (pré-BCR). Iga e $\lg \beta$ também formam parte do receptor em células $B$ maduras. Este receptor é expresso 
transitoriamente e sua estrutura é semelhante ao receptor da célula $B$ madura, e tem grande importância no processo de desenvolvimento das células $B$. A importância do pré-BCR é demonstrada em camundongos knockout para os genes que codificam a cadeia $\mu$ ou um dos genes do surrogate light chains, resultando em redução marcante de células B maduras (Meffre et al., 2000; Rolink et al., 1999; Schebesta, 2002; Löffert et al., 1996).

A proteína tirosina quinase de Bruton (Btk) é expressa em neutrófilos e na geração de células pré-B, porém um defeito nesta proteína ocasiona danos apenas nas células pré-B, paralisando sua maturação. Ela é ativada após o pré-BCR e é requerida como transdutora de sinais para este receptor e para o desenvolvimento, proliferação e diferenciação dos estágios de célula pré-B (Cunningham-Rundles e Ponda, 2005).

Btk tem função essencialmente direta no ciclo celular BCR induzindo a maturação de células B (Anderson et al., 1996). Ela é expressa durante toda a diferenciação das células $B$, mas na transição para as células $B$ maduras sua é expressão é regulada negativamente (de Weers et al., 1993; Hendriks et al., 1996). Embora Btk também esteja presente nas células mielóides e eritróides, estas linhagens celulares parecem não serem afetadas em pacientes com XLA ou xid, porém esta proteína não é expressa em linhagens de células $T$. Em adição, Btk também tem sido implicada como um mediador na sinalização de outros receptores como: FcE; IL-5; IL-6; IL-10; receptor colágeno; receptor eritropoietina e receptor de Toll-like (Kawakami et al., 1994; Sato et al., 1994; Matsuda et al., 1995; Go et al., 1990; Quek et al., 1998; Schmidt et al., 2004; Jefferies et al., 2003). Logo após sua identificação, tem se demonstrado que Btk é ativada por estimulação de BCR, e estudos bioquímicos em células deficientes desta proteína demonstraram que Btk é um importante regulador da mobilização de cálcio induzido por BCR (Takata et al., 1996; Fluckiger et al., 1998).

$\mathrm{Na}$ medida em que as células pré-B grandes se diferenciam em células pré-B pequenas, inicia-se o rearranjo dos genes das cadeias leves das lg e o controle positivo das RAG-1 e RAG-2. Uma vez que o gene para cadeia leve tenha sido rearranjado com êxito, as cadeias leves são sintetizadas e combinadas com a cadeia pesada para formar uma IgM intacta. A IgM aparece na superfície celular juntamente com as cadeias Iga e lg $\beta$ para formar o complexo de receptor da célula $B$ funcional. É neste estágio que a célula sofre o primeiro processo de seleção 
negativa. Experimentos onde camundongos expressaram uma molécula de Iga truncada no domínio citoplasmático, foi observada redução no número de células $B$ imaturas na medula óssea, mostrando o papel da Iga na sinalização para prosseguimento de maturação das células B (Hardy et al., 1991; Allman e Hardy, 1999). O processo de maturação dos linfócitos $B$, suas etapas e proteínas envolvidas estão esquematizadas na figura 3.
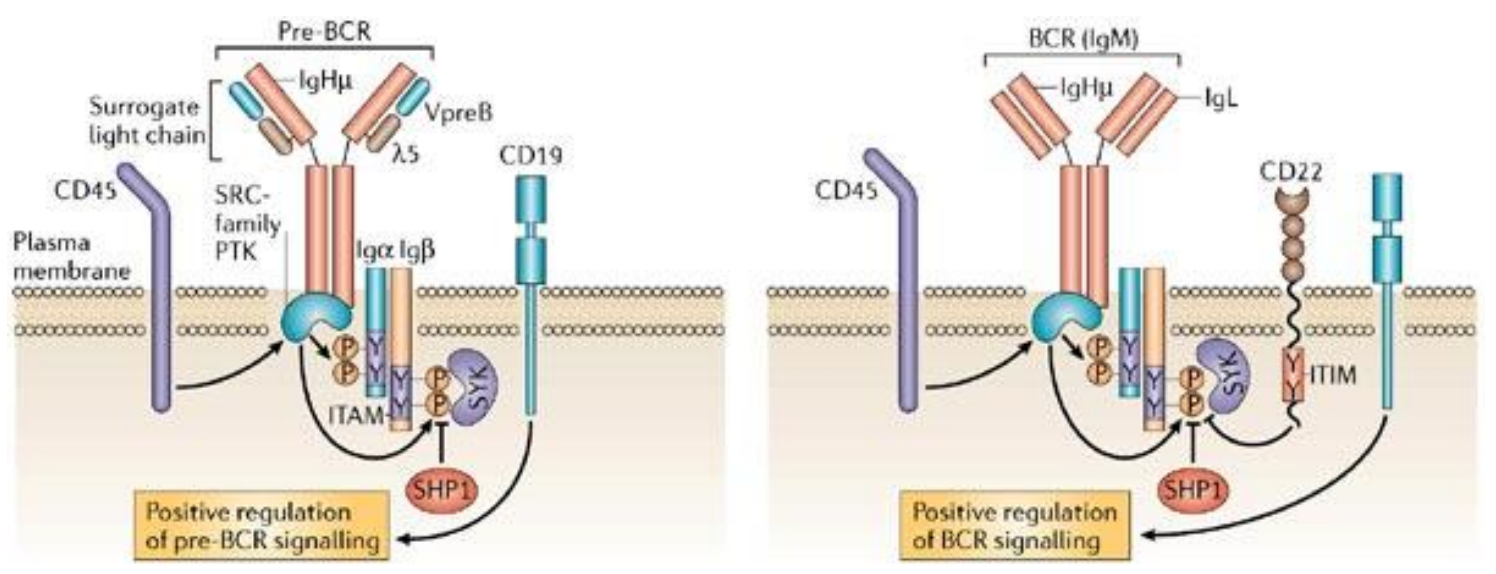

Copyright $\circledast 2006$ Nature Publishing Group Nature Reviews | Immunology

Figura 3. Esquema das estruturas envolvidas no complexo pré-BCR (receptor das células pré-B) nas células $B$ imaturas e do complexo BCR (receptor das células $B$ ) nas células $B$ maduras. Composição do receptor de célula pré-B (pré-BCR) e complexos BCR. O pré-BCR e BCR contém uma forma transmembrânica de imunoglobulina de cadeia pesada $(\lg \mathrm{H})$ que é associada de forma não covalente ao heterodímero de $\lg \alpha$ e $\lg \beta$, e a cadeia leve substituta (SLC), que é composta de $\lambda 5$ e VpreB, ou a cadeia leve das Imunoglobulinas (IgL), respectivamente. A sinalização é provavelmente iniciada pela familia SRC da proteina tirosina quinase (PTK) mediando fosforilação de $\lg \alpha$ e $\lg \beta$ em seqüências de ativação (motifs) de imunoreceptores de tirosina (ITAMs), desse modo gerando locais de ligação para domínio citosólico homology 2 (SH2) contendo PTK tirosina quinase do baço. CD19 e CD45 interagem com pré-BCR e BCR e são reguladas positivamente na sinalização. Inversamente, co-receptores como CD22, CD72, CD5 e pares de receptores de imunoglobulinas leves B (PIRB) são reguladores negativos da sinalização de BCR. Estas proteinas transmembrânicas contém seqüencias inibidoras (motifs) de imunoreceptores tirosina (ITIMs) que são substratos para PTK e funcionam para recrutar proteínas tirosina citosólica fosfatases (PTPs). (Monroe, 2006).

\subsection{Tirosina Quinase de Bruton}

A agamaglobulinemia ligada ao X (XLA) é causada por mutações no gene btk, identificado e mapeado na porção média do braço longo do cromossomo X (Xq21.322), o qual é constituído por 19 exons e possui $37,5 \mathrm{~Kb}$ de extensão. Dos 19 exons, 
18 são responsáveis pela codificação de uma proteína pertencente à família das tirosinas quinases - Src - denominada "Bruton's Tyrosine Kinase" (BTK). Esta proteína está diretamente envolvida no desenvolvimento e maturação das células $B$. Btk forma uma família distinta junto com Tec, Itk e Bmx, chamadas Família Tec. Elas recebem este nome devido a proteína Tec ter sido a primeira quinase a ser isolada. As quinases da família Src são geralmente ancoradas à membrana celular por meio de uma porção lipídica localizada na região $\mathrm{N}$-terminal e têm, em comum, 5 domínios estruturais: PH (pelckstrin homology domain); TH-BTK (Tec homology domain); SH3 (Src homology 3 domains); SH2 (Src homology 2 domains) e o domínio catalítico da tirosina quinase (SH1 - Kinase) (Xu et al., 1997; Nera et al., 2000; Vihinen et al., 2000; Smith et al., 2001; Gauld et al., 2002).

O domínio pelckstrin homology $(\mathrm{PH})$, comumente encontrado em proteínas sinalizadoras eucarióticas, possui aproximadamente 100 aminoácidos e ocorre em muitas proteínas envolvidas na sinalização intracelular e na constituição do citoesqueleto celular. Apesar da função deste domínio ainda não estar totalmente esclarecida, existem várias hipóteses, como tendo sítio de ligação das subunidades $\beta-\delta$ da proteína heterotrimérica G; de lipídios; dos resíduos de serina ou treonina, de proteínas quinases $\mathrm{C}$ e de ancoragem da proteína a superfície celular (Hyvönen e Saraste, 1997; Shen e Vihinen, 2004; Vihinen et al., 2000).

O domínio TH contém uma seqüência especifica (motif) de ligação de zinco com cisteína e histidina conservadas, e geralmente está localizado na porção CTerminal do domínio PH. A estrutura cristalográfica desta região demonstra que os segmentos de uma seqüência específica (motif) denominada BTK interagem com os domínios $\mathrm{PH}$, e a esta interação denominou-se Tec homology (TH) - (Btk-PH). Os oito resíduos localizados na porção extrema do domínio Btk-PH possuem um núcleo hidrofóbico, que aparentemente é importante para a estabilidade da proteína. Os 27 resíduos da porção $\mathrm{N}$-terminal de TH são altamente conservados e são seguidos de uma região rica em prolina (PRR): o motif BTK contém uma histidina conservada e três resíduos de cisteína que estão envolvidos com o zinc finger, enquanto PRR está envolvido nas interações proteína-proteína. O domínio $\mathrm{TH}$, contendo as regiões Btk e PRR, não é encontrado nas outras proteínas da família da tirosina quinase, além da proteína Btk, e pode ser o marcador mais importante desta proteína quinase citoplasmática (Xu et al., 1997; Smith et al., 2001; Shen e Vihinen, 2004). 
O Src homology 3 (SH3) liga-se a regiões ricas em prolina (RRP) e em aminoácidos hidrofóbicos das proteínas alvo. Este domínio é formado por módulos de pequenas proteínas contendo aproximadamente 50 resíduos de aminoácidos e são encontradas em uma grande variedade de proteínas intracelulares ou associadas à membrana, como nas várias proteínas com atividade enzimática, nas proteínas adaptadoras sem seqüências catalíticas e nas proteínas do citoesqueleto (Vihinen et al., 1994; Vihinen et al., 2000; Nera et al., 2000).

O domínio Src homology 2 (SH2) é constituído de aproximadamente 100 aminoácidos, e funciona como módulos regulatórios de sinalização de cascatas intracelulares, interagindo com elevada afinidade aos peptídeos alvo de fosfotirosina contendo uma seqüência-específica. A ligação dos domínios SH2 as fosfotirosinas é um mecanismo crucial para o recrutamento intracelular de moléculas de sinalização para o receptor ativado. A diferenciação entre os domínios $\mathrm{SH} 2$ das diferentes proteínas está no reconhecimento entre os resíduos 3-6 da região $\mathrm{N}$-terminal da tirosina fosforilada (Vihinen et al., 2000; Guo et al., 2005).

O domínio quinase está presente numa extensa família de proteínas que compartilham de um núcleo catalítico conservado comum com as proteínas quinases serina/treonina e tirosina. Há um grande número de regiões com aminoácidos conservados no domínio catalítico da proteína quinase. Na região $\mathrm{N}$-terminal do domínio catalítico há um estiramento dos resíduos ricos em glicina próximos ao resíduo de lisina, que demonstrou estar envolvido na ligação do ATP. Na parte central do domínio catalítico há um resíduo conservado do ácido aspártico que é importante para a atividade catalítica da enzima (Vihinen et al., 2000; Guo et al., 2005; Lindvall et al., 2005). 


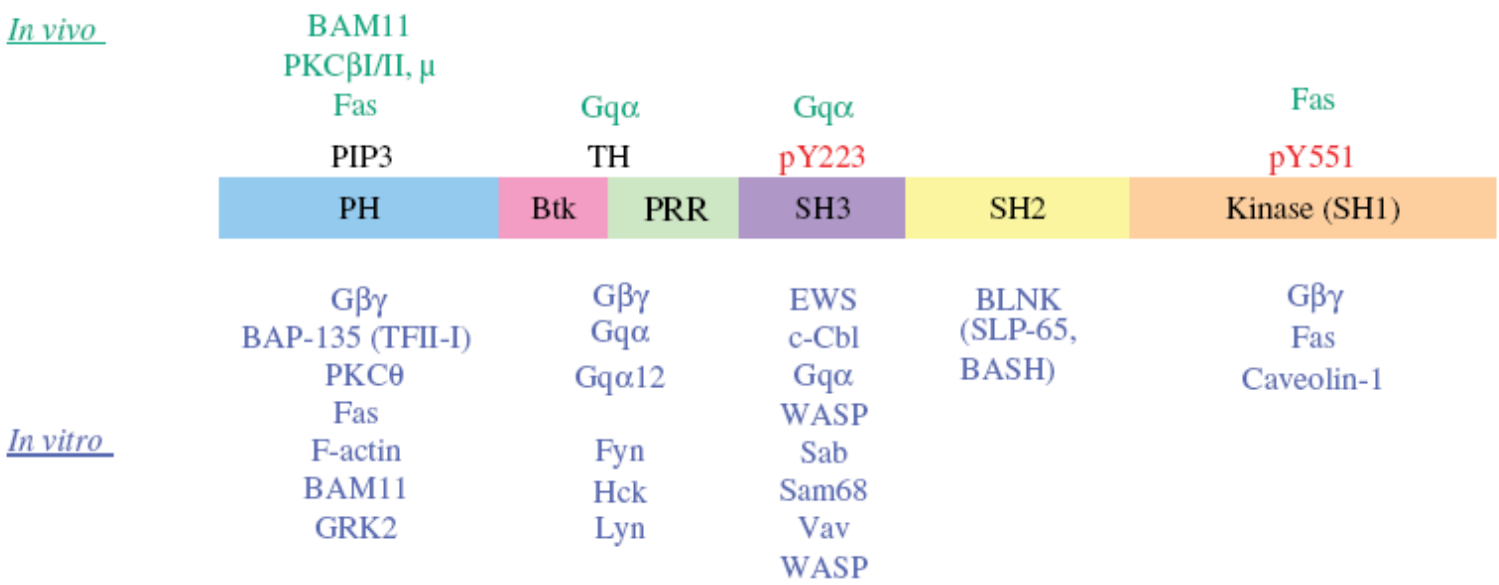

Figura 4. Modelo esquemático de BTK demonstrando diferentes domínios e interação molecular in vivo e in vitro. O domínio homólogo Tec (TH) é internamente dividido com a seqüência Bruton (motif) tirosina quinase (Btk) e região rica em prolina (PRR). PIPs participa na ligação do domínio PH e na ativação de Btk. Os dois sítios de fosforilação (pY223 e pY551) estão representados em vermelho. (Lindvall et al., 2005).

Btk é fosforilada por Syk ou Lyn da família das tirosina quinase Src, na posição Y551 no domínio quinase, promovendo sua atividade catalítica e resultando na autofosforilação do resíduo Y223 no domínio SH3 (Rawlings et al., 1996). Embora a fosforilação de Y223 pareça não ter influência na atividade catalítica de Btk, ela impede a ligação de WASP (Wiskott Aldrich Syndrome Protein) e aumenta a afinidade para Syk (Morrogh et al., 1999). Concomitantemente, a ativação de Syk resulta na fosforilação de SLP-65, que é o elemento central da sinalização de préBCR e BCR. A fosforilação de SLP-65 provém sítios para várias proteínas sinalizadoras incluindo Grb2, Vav, Nck, PLC-y2, Btk e a subunidade Iga do complexo pré-BCR e BCR (Jumaa et al., 2005; Kersseboom et al., 2006).

Os diferentes padrões de interações variam de proteínas citosólicas para fatores de transcrição nuclear, dando a Btk uma diversidade de funções e a colocando como um componente de múltiplas vias de sinalização, sendo a via de sinalização para o receptor de célula $B$ o mais elucidado. Embora, na última década, muito tenha sido aprendido sobre os eventos relatados da sinalização de BCR, o papel preciso de BTK nestas vias ainda é pouco esclarecido. Entretanto, fortes evidências indicam que a expressão de Btk é essencial em muitas etapas cruciais no ciclo de vida das células da linhagem $B$, induzindo a proliferação, desenvolvimento, diferenciação e apoptose (Gauld et al., 2002; Lindvall et al., 2005).

Resíduos de tirosina reúnem se dentro de supostas seqüências ativadoras (motif) de imunoreceptores de tirosina na porção citoplasmática dos heterodímeros 
de $\lg \alpha / \lg \beta$, que são fosforilados por membros das famílias quinases $\mathrm{Src}$, criando segmentos de sítios de ligação para não receptores de tirosina quinase e proteínas adaptadoras. Em adição, como resultado de ativação de fosfoinositídeo-3-quinase (PIK-3), níveis de fosfatidilinositol-3,4,5-trifosfato $\left(\mathrm{PIP}_{3}\right)$ na parte interna da membrana movimentam-se, conduzindo, através do domínio $\mathrm{PH}$, a translocação da proteína Btk para a membrana plasmática (Salim et al., 1996; Scharenberg et al., 1998; Mohamed et al., 1999).

A ativação de Btk também pode ocorrer em seguida à estimulação de diversas séries de receptores de superfície celular (Nore et al., 2000). O primeiro evento ocorre na membrana plasmática, onde membros da família quinase fosforilam Btk no resíduo de tirosina (Y551), importante na ativação do "loop" do domínio quinase, seguido da autofosforilação do resíduo Y223 no domínio quinase (Kersseboom et al., 2006). Após esta etapa, a Btk fosforilada recruta a proteína adaptadora de ligação de células B (BLNK) junto com a fosfolipase C-ү2 (PLC-ү2) na membrana plasmática, trazendo para bem perto da proteína Syk, onde a fosforilação da tirosina ocorre em ambas as proteínas (Rodriguez et al., 2001; Guo et al., 2004).

A fosforilação e subseqüente ativação de PLC-y2 conduzem a hidrólise de fosfoinositideo Ptdlns $(4,5) \mathrm{P}_{2}$ para a produção de $\operatorname{Ins}(1,4,5) \mathrm{P}_{3}$ e diaciglicerol (DAG), causando a mobilização de cálcio e ativando a proteína quinase $C$ (PKC), respectivamente (Guo et al., 2004). Em células deficientes ou com baixa expressão de Btk tem se mostrado ocorrer a parada de mobilização de cálcio intracelular dependente de BCR. A sinalização na membrana plasmática por Btk acredita-se ocorrer, predominantemente, em ambiente rico em colesterol e esfingolipídeo. Notavelmente a sinalização de Btk na membrana plasmática também envolve eventos no citoplasma e núcleo. Com isto, a transdução de sinal envolvendo Btk tem sido mostrada na ativação da transcrição do fator nuclear regulador KB (NFKB), em seguida do envolvimento da BCR e lipopolissacarídeo (LPS), e da estimulação dos receptores de Toll-Like (Petro et al., 2000; Bajpai et al., 2000; Horwood et al., 2003; Schmidt et al., 2006). Além disso, os fatores de transcrição têm se mostrado serem alvos direto de Btk, reiterando seu papel na expressão e regulação destes genes (Yang et al., 1997; Novina et al., 1999; Webb et al., 2000), e que através de modulação direta da atividade de pequenas GTPases, Btk pode induzir remodelagem robusta do citoesqueleto nas células estimuladas (Inabe et al., 2002). 


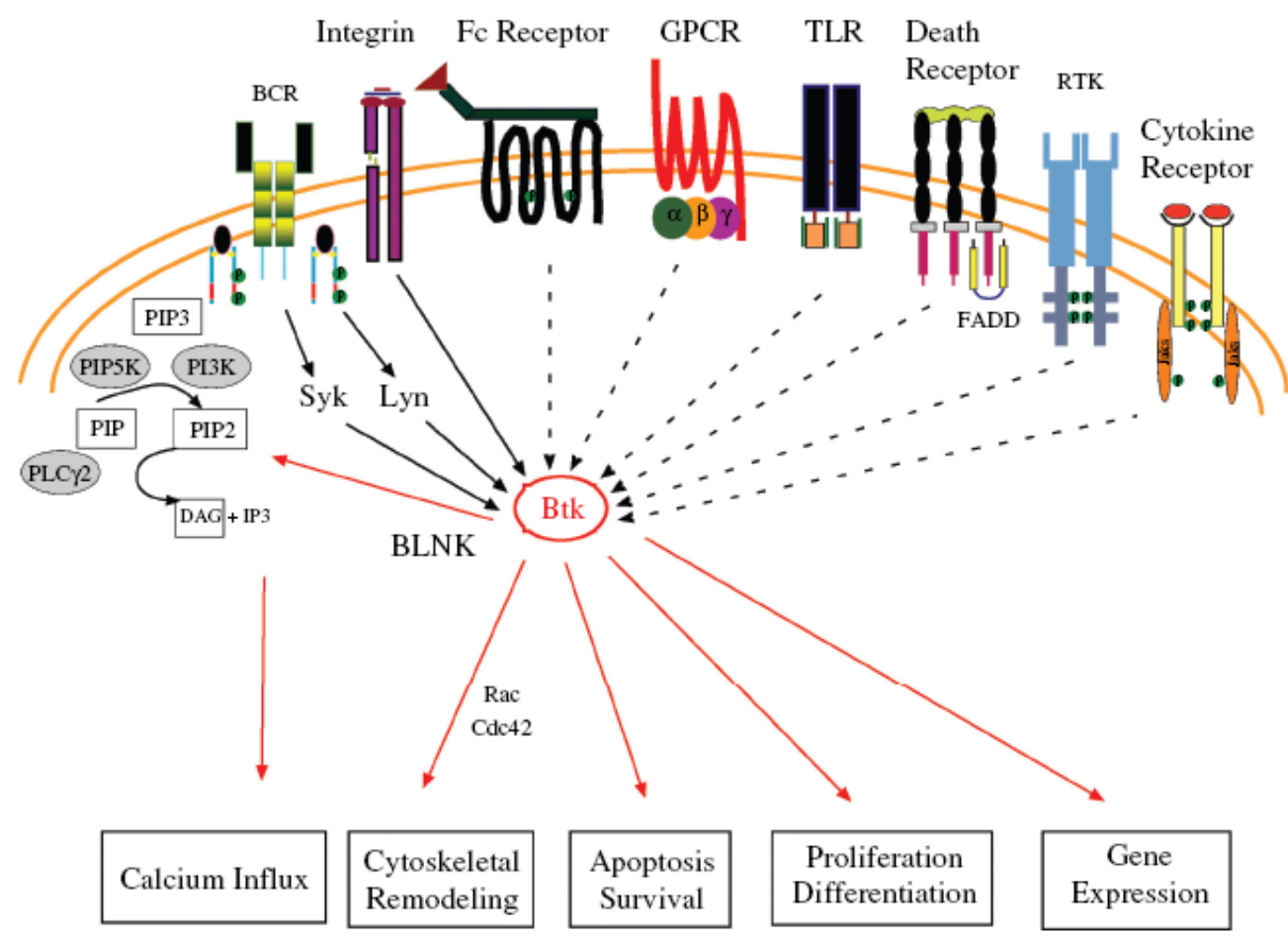

Figura 5. Modelo esquemático das vias de sinalização de Btk. Devido à estrutura multimodular da proteína Btk e das diversas moléculas que podem interagir com ela, é de prever que esta quinase provoca múltiplas vias de sinalização, gerando efeitos pleiotrópicos. RTK, Receptor de tirosina quinase - BCR, GPCR, Receptor proteína G, TLR. Setas interrompidas representam vias de sinalização que ainda não são completamente elucidadas (Lindvall et al., 2005).

Mutações nos diferentes sítios dos domínios desta proteína levam ao comprometimento da atividade protéica e conseqüentemente afetando a maturação das células B, levando ao quadro de XLA. Todas as mutações no gene btk que foram descritas e publicadas, estão relacionadas no BTKbase. Este banco de dados com registro das mutações de XLA foi estabelecido em 1994, e a sua última atualização foi publicada em 2006 (Btk base web page www.bioinfo.uta.fi/BTKbase/structure.html (Väliaho et al., 2006).

Até a finalização do presente estudo, não temos relatos na literatura da descrição de mutações e suas manifestações clínicas em pacientes com agamaglobulinemia na população brasileira. Considerando-se que os relatos destes dois aspectos da agamaglobulinemia foram bem caracterizados em países desenvolvidos (EUA e Europa), onde as etnias e condições socioeconômicas são bem definidas, o presente estudo teve como principal objetivo descrever 0 
comportamento das mutações e suas implicações clínicas da agamaglobulinemia em nossa população, onde a miscigenação racial e as condições socioeconômicas são extremamente diversas, confrontando com os achados clínico-moleculares já publicados. 


\section{Objetivos}

\subsection{Objetivo Geral}

Estudar o gene btk em pacientes com ausência ou número reduzido de linfócitos $B$ em sangue periférico.

\subsection{Objetivos Específicos}

2.2.1. Identificar as mutações do gene btk em pacientes com número de linfócitos $\mathrm{B}$ em sangue periférico abaixo de $2 \%$;

2.2.2. Estudo das características clínicas e laboratoriais com as mutações descritas.

2.2.3. Confrontar com os dados clinico-moleculares com os estudos multicêntricos desenvolvidos em países desenvolvidos. 


\section{Casuística}

O protocolo deste estudo foi aprovado pela Comissão de Ética em Pesquisa com Seres Humanos do Instituto de Ciências Biomédicas da USP e pela Comissão de Ética e Pesquisa dos respectivos serviços.

As amostras de sangue foram colhidas após a obtenção do consentimento verbal e por escrito dos adultos responsáveis pelas crianças e dos adultos participantes, depois dos devidos esclarecimentos quanto à natureza e o objetivo do estudo (Anexo I).

\subsection{Pacientes}

Foram avaliados 33 pacientes que estão sendo acompanhados nos serviços da Disciplina de Alergia, Imunologia e Reumatologia do Departamento de Pediatria da UNIFESP e da Unidade de Alergia e Imunologia do Instituto da Criança-FMUSP.

Os controles saudáveis foram representados por 15 adultos jovens, estudantes do programa de pós-graduação do Departamento de Imunologia do ICBUSP. Não foi possível a seleção de crianças pareadas por idade e sexo, face à necessidade de se colherem quantidades significativas de sangue para análises e pela não identificação de benefícios para controles normais pediátricos que pudessem justificar o procedimento.

\subsection{Critérios Clínicos-Laboratoriais de Inclusão dos Pacientes}

O critério de inclusão foi fundamentalmente 0 diagnóstico de Agamaglobulinemia congênita, segundo os critérios do Grupo Pan-Americano de Imunodeficiência (PAGID) (Conley et al., 1999):

1. Definitivo: menino com menos de $2 \%$ de células CD19+ (linfócitos B) e, pelo menos, um dos seguintes critérios:

a) Mutação no gene btk; 
b) Ausência de mRNA para Btk em análise de Northern blot de neutrófilos e monócitos;

c) Ausência da proteína Btk em monócitos ou plaquetas;

d) Primos maternos, tios ou sobrinhos com menos de $2 \%$ de células CD19+ (linfócito B).

2. Provável: menino com menos de $2 \%$ de células CD19+ (linfócitos B) e com todos os seguintes critérios:

a) Início de infecções bacterianas de repetição nos primeiros 5 anos de vida;

b) Níveis de $\lg$, IgA e $\operatorname{lgM}$ muito reduzidos (menos que 2 desvios-padrão (SD) para idade);

c) Ausência de resposta pós-vacinal e de isohemaglutininas;

d) Outras causas de hipogamaglobulinemia excluídas.

3. Possível: menino com menos de $2 \%$ de células CD19+ (linfócitos B) no quais outras causas de hipogamaglobulinemia tenham sido excluídas, e no mínimo um dos critérios:

a) Início de infecções bacterianas de repetição nos primeiros 5 anos de vida;

b) Níveis de $\lg \mathrm{G}$, $\lg \mathrm{A}$ e $\lg \mathrm{M}$ muito reduzidos (menos que 2 SD para idade);

c) Ausência de isohemaglutininas.

\subsection{Anamnese dos pacientes}

Uma ficha de avaliação clínica foi preenchida (Anexo II), baseando-se nas informações solicitadas pelo European Society for Immunodeficiency (ESID) e LatinAmerican Group of Immunodeficiency (LAGID) para o registro dos casos de imunodeficiência, sistematizando assim as informações.

Foram coletadas informações dos prontuários dos pacientes referente à sua primeira consulta ao serviço pelo qual ele está sendo acompanhado (Anexo III). 


\section{$4 \quad$ Material e Métodos}

\subsection{Extração de DNA genômico a partir de sangue periférico}

Para a obtenção do material genético padronizou-se o método de extração "Salting out modificado" (Miller et al, 1988; Martinez et al, 1998; Noguera et al, 2000). Amostras de sangue foram coletadas em tubo contendo EDTA. Alíquotas de $300 \mu \mathrm{L}$ de sangue foram homogeneizadas com $1 \mathrm{ml}$ de Solução de Lise, incubadas por 5 minutos a temperatura ambiente e centrifugadas por 5 minutos a $3.800 \mathrm{xg}$. Repetiuse este procedimento até o pellet estar limpo e o sobrenadante claro.

O pellet foi homogeneizado com $500 \mu \mathrm{L}$ da Solução de Extração contendo $80 \mu \mathrm{g} / \mathrm{ml}$ de Proteinase K. A solução foi incubada a $56{ }^{\circ} \mathrm{C}$ por duas horas, adicionando-se, posteriormente, $200 \mu \mathrm{L}$ de Cloreto de Sódio na concentração $6 \mathrm{M}$ para ocorrer à separação das frações protéicas dos Ácidos Nucléicos. As amostras foram agitadas em agitador até a obtenção de uma mistura densa. Centrifugou-se por 3 minutos a $6.700 \mathrm{xg}$ e o sobrenadante foi transferido para um novo microtubo estéril contendo $700 \mu \mathrm{L}$ de Isopropanol ocorrendo, nesta etapa, a precipitação do DNA. Em seguida, realizou-se a centrifugação por 5 minutos a $3.800 \mathrm{xg}$ em baixa temperatura, o sobrenadante foi cuidadosamente desprezado e o pellet foi lavado duas vezes com Solução de Etanol 70\%. Após a lavagem, centrifugou-se a 12.000 xg por 3 minutos em baixa temperatura e, após seco, o pellet foi eluído em Solução de TE (Tris-EDTA) 10:1 e incubado por 30 minutos a temperatura de $60 \stackrel{\circ}{ } \mathrm{C}$, para ocorrer a total solubilização.

A extração realizada por esta técnica fornece excelente rendimento e integridade do DNA quando comparada com outros métodos de extrações.

\subsection{Determinação do DNA Genômico}

Após a extração, as amostras foram quantificadas em gel de agarose a 1,2\% em tampão TAE (Tris-Acetato/EDTA), por comparação com padrão de massa molecular conhecida (High DNA mass Ladder - Invitrogen - catálogo № 10496-016). 
As amostras de DNA que foram utilizadas nas reações de PCR foram diluídas a uma concentração de $25 \mathrm{ng} / \mu \mathrm{L}$. Os estoques foram armazenados à $-20^{\circ} \mathrm{C}$.

As amostras também foram submetidas à análise por espectrofotometria, onde as leituras da $\mathrm{DO}_{260}$ e $\mathrm{DO}_{280}$ foram obtidas e a razão entre elas - $\mathrm{DO}_{260 / 280}$ permaneceu entre 1,8 e 2,0, demonstrando baixo risco de contaminação por proteínas.

\subsection{Reação de Polimerase em Cadeia - PCR (Polymerase Chain Reaction)}

Com o intuito de estudar possíveis alterações na estrutura do DNA para o gene btk, as amostras de todos os pacientes foram submetidas à reação de polimerase em cadeia - PCR - para todos os 19 exons que constituem o gene. Os iniciadores utilizados para a amplificação dos exons do gene btk foram sintetizados baseados no estudo de Conley e colaboradores (1994). As reações de PCR foram padronizadas nos termocicladores PTC - 100 (MJ Research) e MasterCycle (Eppendorf), utilizando-se um volume total de reação de $25 \mu \mathrm{L}$ contendo: $1 \mathrm{x}$ tampão da TAQ (Invitrogen), 1,5 mM de $\mathrm{MgCl}_{2}$ (Invitrogen), $200 \mu \mathrm{M}$ de dATP, $200 \mu \mathrm{M}$ de dTTP, $200 \mu \mathrm{M}$ de dCTP, $200 \mu \mathrm{M}$ de dGTP (Invitrogen - catálogo o 10297-018), 0,2 $\mu \mathrm{M}$ de cada iniciador, 1.5 U Taq DNA polimerase (Invitrogen - catálogo no ${ }^{11615}$ 010) e 50 ng de DNA genômico. As condições de amplificação foram padronizadas em:

$$
\begin{aligned}
& 94^{\circ} \mathrm{C}-3 \text { minutos } \\
& 94{ }^{\circ} \mathrm{C}-1 \text { minuto } \\
& \begin{array}{l}
\text { T. A. }-1 \text { minuto } \\
72{ }^{\circ} \mathrm{C}-1 \text { minuto e } \\
\quad 30 \text { segundos }
\end{array} \\
& 72{ }^{\circ} \mathrm{C}-8 \text { minutos }
\end{aligned}
$$

Para se verificar o tamanho e a qualidade dos produtos obtidos, ao final de cada reação, uma alíquota de $5 \mu \mathrm{L}$ foi submetida a corrida eletroforética em gel de agarose a 1,5\%, juntamente com padrão de tamanho de fragmentos de DNA (100 bp 
DNA Ladder - Invitrogen - catálogo oํ 15628-019). As temperaturas, seqüências dos iniciadores e tamanho do fragmento amplificado estão descritos no Anexo IV.

O procedimento acima descrito foi utilizado para amplificação de todos os exons do gene btk dos controles saudáveis.

\subsection{Triagem das amostras utilizando a técnica Polimorfismo conformacional de simples fita - Análise heteroduplex - "single-strand conformation polymorphisms/ heteroduplex analysis" (SSCP/HA)}

Para a triagem de mutação, utilizou-se as técnicas de polimorfismo conformacional de fita simples (SSCP) (Orita et al., 1989) associada à análise de heteroduplex (HA) (Nagamine et al., 1989). A técnica de SSCP baseia-se no fato de que a conformação tridimensional de fragmentos de DNA simples-fita depende da seqüência de nucleotídeos, sendo que a diferença de um nucleotídeo altera o padrão de migração eletroforética. A técnica de HA baseia-se nas reações de PCR onde estão presentes moléculas de DNA selvagens e mutantes, e que durante os últimos ciclos, podem formar heteroduplexes entre essas duas moléculas, as quais terão um padrão de migração eletroforética diferente dos homoduplexes. A associação destas duas técnicas eleva a sensibilidade do método (Arnold et al., 1999), que quando separadas, apresentam uma sensibilidade de até $75 \%$, e a análise da técnica SSCP em duas temperaturas também contribui no aumento da eficácia e reprodutibilidade.

Para a análise em SSCP/HA, modificações no protocolo original da reação da PCR foram efetuadas, onde se adicionou, na mesma reação, $50 \mathrm{ng}$ de DNA genômico da amostra alvo e $50 \mathrm{ng}$ de DNA genômico de uma amostra controle, entretanto com as amostras controles permaneceu o protocolo original.

Após a amplificação dos 19 exons do gene btk de cada amostra, o produto obtido desta amplificação foi analisado por meio da técnica de "single-strand conformation polymorphisms/ heteroduplex analysis" (SSCP/HA), descrita abaixo, para detectar possíveis alterações no gene.

Os produtos de PCR dos pacientes e dos controles a serem analisados foram diluídos na proporção de 1: 2 em solução desnaturante permitindo a formação dos hetero e homoduplexes. Estas foram submetidas à temperatura de $95{ }^{\circ} \mathrm{C}$, em 
termociclador PTC - 100, MJ Research, pelo tempo de 5 minutos e imediatamente submetidas a banho de gelo, permanecendo por 15 minutos.

Em seguida, $6 \mu \mathrm{L}$ de cada amostra foi submetido à corrida eletroforética em gel de poliacrilamida à 12,5\% não-desnaturante (GeneGel Excel 12.5/24Kit - GE Healthcare Bio-Sciences - catálogo no 17-6000-14) utilizando-se o sistema GenePhor Electrophoresis Unit (GE Healthcare Bio-Sciences - catálogo no 18-111582) com as seguintes condições: $7 \stackrel{\circ}{\circ} \mathrm{C}$ e $20^{\circ} \mathrm{C}, 600 \mathrm{~V}, 25 \mathrm{~mA}, 15 \mathrm{~W}$ por 1 hora e 30 minutos. Após a corrida eletroforética, os géis foram submetidos à coloração com prata, utilizando-se o Hoefer Automated Gel Stainer (GE Healthcare Bio-Sciences catálogo no 80-6330-04) com o PlusOne DNA Silver Staining Kit (GE Healthcare BioSciences - catálogo oㅜ 17-6000-30).

Como método alternativo, executamos colorações com Nitrato de Prata dos géis de poliacrilamida de forma manual (Sanguinetti et al., 1994), como descrito:

Após a corrida eletroforética, os géis foram submersos em Solução Fixadora por 20 minutos, seguido da Solução de Coloração $(0,2 \%$ de Nitrato de Prata) por mais 20 minutos. Após estas etapas, os géis foram lavados e submetidos à Solução Reveladora até o surgimento das bandas dos fragmentos de DNA, quando a reação foi bloqueada com Solução Bloqueadora. Todas as etapas foram realizadas sob suave agitação e em temperatura ambiente.

Todas as amostras que apresentaram padrão de bandas alterado em relação ao controle normal foram seqüenciadas.

\subsection{Seqüenciamento}

Para o seqüenciamento, novas amplificações dos exons com padrão de banda alterado foram realizadas, utilizando-se os mesmos iniciadores e as mesmas condições descritas no item 4.3. Após a amplificação, os produtos de PCR foram purificados com o GFX ${ }^{T M} P C R$ DNA and Gel Band Purification Kit (GE Healthcare Bio-Sciences - catálogo no 27-9602-01) e quantificados em gel de agarose a $2 \%$ por comparação com padrão de massa molecular Low DNA Mass Ladder (Invitrogen catálogo no 10068-013).

Após a quantificação, as mesmas foram seqüenciadas. As reações do seqüenciamento foram realizadas utilizando-se os mesmos jogos de iniciadores 
descritos para cada exon e o DYEnamic ET Dye Terminator Kit (com Thermo Sequenase $^{\mathrm{TM}}$ II DNA Polimerase - GE Healthcare) com dideoxinucleotídeo marcado com fluorescência. A leitura automática do seqüenciamento foi realizada utilizando o MegaBACE 1000 - um sistema de análise de DNA de 96 capilares - (GE Healthcare).

As seqüências foram analisadas usando o editor de seqüências biológicas BioEdit (Ibis Therapeutics - Carlsbad, CA, EUA) e comparadas com a seqüência de DNA depositadas no GenBank (gi:2281904/locus HSU78027) utilizando o programa Basic Local Alignment Tool (Blast) do National Center For Biotechnology Information (NCBI).

Estes seqüenciamentos foram realizados pelo Centro de Estudos do Genoma Humano - IB - USP.

\subsection{Extração de RNA total a partir de sangue periférico}

Para a obtenção do RNA, optou-se em separar as células mononucleares de sangue periférico e proceder a extração a partir desta população celular.

Então, para a extração do RNA total foram coletados $10 \mathrm{ml}$ de sangue em tubo de coleta contendo heparina. As amostras foram transferidas ao laboratório em temperatura ambiente e seu processamento foi imediato.

O sangue foi diluído em uma solução tampão salina (PBS 1x) estéril na diluição 1: 2 e transferido, vagarosamente, para outro recipiente contendo $15 \mathrm{ml}$ de Ficoll - Hystopaque densidade 1077 (Sigma-Aldrich - catálogo № 1077-1), para ocorrer a separação dos granulócitos e leucócitos mononucleares do sangue periférico. Após a transferência, a amostra foi centrifugada a $1.800 \mathrm{xg}$ por 30 minutos a temperatura ambiente.

Após a centrifugação, observou-se claramente a formação de um anel branco, contendo as células mononucleares, na interfase entre o plasma sanguíneo e o Ficoll. Este anel foi totalmente removido, com ajuda de pipeta Pasteur, e acondicionado em um novo recipiente. As células foram lavadas duas vezes com PBS $1 \mathrm{x}$ estéril e centrifugadas a $1.800 \mathrm{xg}$ por 20 minutos a temperatura ambiente. Após a lavagem, as células foram contadas em câmera de Neubauer e para cada $6 \times 10^{6}$ céls/ ml adicionou-se $1 \mathrm{ml}$ de Trizol ${ }^{\circledR}$ Reagent (Invitrogen - catálogo oㅜ 15596- 
026) que é uma solução monofásica de fenol e isotiocianato de guanidina e baseiase no método desenvolvido por Chomcznski e Sacchi (1987). Durante a homogeneização ou lise das amostras o Trizol $^{\circledR}$ Reagent mantém a integridade do RNA.

Após esta etapa, seguiu-se o protocolo de extração conforme instruções do fabricante. As amostras com trizol foram incubadas por 5 minutos a temperatura ambiente para completa dissociação dos complexos protéicos. Após a incubação, adicionou-se $200 \mu \mathrm{L}$ de Clorofórmio para cada $1 \mathrm{ml}$ de Trizol utilizado na primeira etapa. Agitou-se vigorosamente e manualmente as amostras por 15 segundos e incubou-se novamente por mais 3 minutos a temperatura ambiente As amostras foram centrifugadas a $12.000 \mathrm{xg}$ por 15 minutos a $6^{\circ} \mathrm{C}$.

Após a centrifugação, observou-se a divisão de três fases. A primeira fase inferior, em vermelho, é a fase fenol-clorofórmio, a segunda fase (em tom esbranquiçado) é onde estão os complexos protéicos e o DNA e uma terceira fase superior (límpida) é onde está o RNA. Esta fase foi transferida para um novo tubo e adicionou-se $500 \mu \mathrm{l}$ de Álcool Isopropílico para ocorrer a precipitação do RNA. As amostras foram incubadas por 10 minutos a temperatura ambiente e centrifugadas a $12.000 \mathrm{xg}$ por 10 minutos a $6^{\circ} \mathrm{C}$.

O pellet de RNA foi lavado com etanol a $75 \%$ preparado em água DEPC e posteriormente centrifugado a $7.500 \times \mathrm{g}$ por 5 minutos a $6{ }^{\circ} \mathrm{C}$. O sobrenadante foi removido e o pellet, após seco, foi dissolvido em $30 \mu$ de água livre DEPC e mantido a $-70^{\circ} \mathrm{C}$.

\subsection{Quantificação do RNA}

Para verificar a integridade do RNA obtido, foi realizada uma corrida eletroforética com $2 \mu \mathrm{l}$ da amostra em gel de agarose a 1\%. A quantificação do RNA foi obtida através da análise por espectrofotometria, onde a leitura da densidade óptica $\left(\mathrm{DO}_{260}\right)$ igual a 1,0 corresponde a $40 \mu \mathrm{g} / \mathrm{ml}$. A razão entre as densidades ópticas $\mathrm{DO}_{260}$ e $\mathrm{DO}_{280}$ foi obtida e permaneceu entre 1,8 a 2,0, demonstrando baixos riscos de contaminação por proteínas e/ou fenol. 


\subsection{Tratamento do RNA com DNase I}

Para eliminar qualquer contaminação das amostras de RNA por DNA, as mesmas foram tratadas com DNase I (DNase I, amplification Grade - Invitrogen catálogo $\mathrm{n}^{\circ}$ 18068-015). A DNase I digere simples fita e dupla-fita de desoxiribonucléicos. A cada $1 \mu \mathrm{g}$ de RNA adicionou-se $1 \mathrm{U}$ de DNase I, Tampão 1x e RNase num volume final de $10 \mu \mathrm{l}$. As amostras foram incubadas por 15 minutos em temperatura ambiente, seguido pela adição de EDTA $(\mathrm{pH} 8,0)$ na concentração final $25 \mathrm{mM}$ e procedeu-se nova incubação por 10 minutos a $65^{\circ} \mathrm{C}$.

\subsection{Reação de Transcriptase Reversa - RT-PCR}

Para a síntese de DNA complementar (cDNA), realizou-se a reação de transcrição reversa (RT) utilizando-se a enzima Superscript ${ }^{\mathrm{TM}}$ III First-Strand Synthesis System for RT-PCR (Invitrogen - catálogo no 18080-051), que reduz a atividade da RNase $\mathrm{H}$ e aumenta a estabilidade termal. Para a reação de síntese da primeira fita de cDNA, catalisada pela enzima Superscript III, foram utilizados $3 \mu \mathrm{g}$ de RNA total, $50 \mu \mathrm{M}$ do iniciador random hexamero, $10 \mathrm{mM}$ de dNTP, $1 \mathrm{x}$ do Tampão da enzima, 0,1 M DTT, $40 \mathrm{U}$ de RNase inibidor, $200 \mathrm{U}$ da enzima Superscript e água livre de RNase e DNase, para um volume final de $20 \mu \mathrm{l}$.

Primeiramente, o RNA foi incubado por 5 minutos a $65^{\circ} \mathrm{C}$ na presença do dNTP e do iniciador random hexamero. Após este período de incubação acrescentou-se à reação o tampão da enzima, DTT, RNase inibidor e a enzima Superscript III e procedeu-se nova incubação por 50 minutos a $42{ }^{\circ} \mathrm{C}$, seguido por 15 minutos a $70{ }^{\circ} \mathrm{C}$, para que ocorra a inativação da enzima. As moléculas de cDNA foram armazenadas a $-20 \stackrel{\circ}{ } \mathrm{C}$.

A reação de PCR para a amplificação do gene btk e do gene $\beta$-actina (expressão constitutiva) nas amostras de cDNA foi previamente padronizada e realizada com $2 \mu \mathrm{g}$ de cDNA de cada amostra, 1x tampão da TAQ (Invitrogen), 1,5 mM de $\mathrm{MgCl}_{2}$ (Invitrogen), $200 \mu \mathrm{M}$ de dATP, $200 \mu \mathrm{M}$ de dTTP, $200 \mu \mathrm{M}$ de dCTP, $200 \mu \mathrm{M}$ de dGTP (Invitrogen - catalogo no 10297-018), 0,2 $\mu \mathrm{M}$ de cada iniciador, 1.5 U de Taq DNA polimerase (Invitrogen - catálogo n 11615-010). Essa reação foi 
incubada em termociclador Master Cycle (Eppendorf) inicialmente a $95 \stackrel{\circ}{\mathrm{C}}$ por 5 minutos, seguido por 35 ciclos a $95 \stackrel{\circ}{\circ}$ por 1 minuto, $60 \stackrel{\circ}{\circ}$ por 1 minuto e $72 \stackrel{\circ}{\circ}$ por 1 minuto, com extensão final a $72 \stackrel{\circ}{\circ}$ por 8 minutos. O produto resultante foi analisado por meio de corrida eletroforética em gel de agarose a 1,5\%, juntamente com padrão de tamanho de fragmentos de DNA (100 bp DNA Ladder - Invitrogen catálogo no 15628-019). As temperaturas, seqüências dos iniciadores e tamanho do fragmento amplificado estão descritos no Anexo IV.

Os iniciadores foram desenhados com o auxilio do programa Primer3 (Whitehead Institute for Biomedical Research, Cambridge, UK) e em regiões interexons para evitar a amplificação de possível DNA genômico presente nas amostras de RNA.

\subsection{Reação Quantitativa Relativa em Tempo Real (Real-Time PCR)}

A reação de $P C R$ quantitativa em tempo real (qPCR) é uma técnica rápida e acurada que permite a determinação direta dos produtos amplificados durante a fase exponencial da reação. Uma das técnicas de realização é por meio da marcação do fragmento amplificado pelo reagente SYBRGreen, que emite fluorescência ao se ligar ao DNA dupla fita recém-sintetizado, e pode ser lido durante a reação por um detector em tempo real. A técnica de qRT-PCR relativa determina a expressão de um gene alvo em relação a um gene expresso de maneira constitutiva, em reações realizadas em condições não limitantes (Burleigh, 2001).

Para a realização dos estudos de PCR quantitativo em tempo real, para o gene btk em comparação ao gene de expressão constitutiva - $\beta$-actina - realizamos a transcrição reversa com $2 \mu \mathrm{g}$ de RNA total, conforme descrito anteriormente no item 4.9. O produto da transcrição reversa foi utilizado nas reações de Real Time PCR utilizando um volume final de reação de $12 \mu \mathrm{l}$, contendo $6,5 \mu \mathrm{l}$ do Platinum $\AA S Y B R \circledast G$ reen qPCR SuperMix-UDG [contêm Platinun Taq DNA polimerase, sonda SYBR $\otimes G$ reen I, Tris- $\mathrm{HCl}, \mathrm{KCl}, 6 \mathrm{mM} \mathrm{MgCl} 2,400 \mu \mathrm{M}$ dGTP, 400 $\mu \mathrm{M}$ dATP, $400 \mu \mathrm{M}$ dTTP , $400 \mu \mathrm{M}$ dCTP, $800 \mu \mathrm{M}$ dUTP, uracil DNA glicolase (UDG)]; $0,5 \mu$ sonda de referencia ROX; $15 \mu \mathrm{M}$ do iniciador sense e $15 \mu \mathrm{M}$ do iniciador anti-sense e $2 \mu \mathrm{g}$ do cDNA de para cada amostra. 
O equipamento utilizado para a realização das reações de amplificação e detecção foi o 7300 Real-Time PCR System (Applied Biosystems) e a análise de quantificação das amostras foi realizada por meio do Software Sequence Detection v.1.3 (Applied Biosystems) através da análise do nível de fluorescência gerado pela incorporação de nucleases fluorogênicas (Sybr Green I) aos produtos de amplificação durante o curso da reação.

As condições de termociclagem compreenderam uma incubação a $50{ }^{\circ} \mathrm{C}$ por 2 minutos, seguida pela ativação da DNA polimerase a $95 \stackrel{\circ}{\circ}$ por 10 minutos, e 40 ciclos de desnaturação a $95{ }^{\circ} \mathrm{C}$ por 15 segundos intercalados com anelamento e extensão a $60^{\circ} \mathrm{C}$ por 1 minuto. Houve também um ciclo final para a obtenção de uma curva de dissociação dos produtos por reação constituída de $95{ }^{\circ} \mathrm{C}$ por 15 segundos, $60 \stackrel{\circ}{\circ}$ por 30 segundos e novamente $95{ }^{\circ} \mathrm{C}$ por 15 segundos finais. A curva de dissociação gera um pico em temperatura especifica para cada fragmento amplificado e pode se observar a presença de produtos amplificados inespecíficos e dímeros de iniciadores. As reações foram preparadas em triplicatas (tanto para o gene alvo quanto para o gene controle), num volume final de $12 \mu$ l, utilizando $2 \mu \mathrm{g}$ de cDNA.

Os iniciadores do gene btk usados na reação foram cuidadosamente desenhados, utilizando o programa Primer3, para evitar a amplificação de produtos inespecíficos e formação de dímeros, uma vez que o SYBGreen se liga a qualquer DNA dupla-fita. As seqüências dos iniciadores dos genes btk e $\beta$-actina para a reação quantitativa em tempo real, suas temperaturas e produto amplificado estão relacionados no Anexo IV.

A intensidade de fluorescência foi medida ao final de cada ciclo de extensão e os valores foram plotados em uma curva onde foi possível visualizar a amplificação exponencial dos produtos de PCR.

A quantificação relativa foi obtida pelos valores delinear do ciclo $(\mathrm{Ct}$ Treshold cycle), no qual o aumento do sinal associado à fase exponencial de amplificação do produto de PCR começa a ser detectado (Ginzinger, 2002). O Ct é um momento da reação que pode ocorrer em qualquer intervalo entre um ciclo e outro da PCR.

O modelo matemático adotado para calcular a intensidade de expressão relativa depende da eficiência de amplificação do gene alvo e do gene controle. Assim foram realizadas reações de qPCR para o gene $B t k$, nas condições descritas 
anteriormente, utilizando amostra de cDNA de um controle normal em diluições seriadas. Para o cálculo da eficiência de amplificação foi aplicada a fórmula $E=10^{(-}$ 1/slope) (Rasmussen, 2001).

O método $2^{-\triangle \Delta C t}$ utiliza um RNA de referência para comparação com as amostras em estudo. Neste estudo foi escolhido o cDNA de um controle normal. Inicialmente, o $\Delta \mathrm{Ct}$ de cada amostra foi calculado pela subtração entre o valor $\mathrm{Ct}$ do gene Btk e o valor $\mathrm{Ct}$ do gene $\beta$-actina de todas as amostras. Em seguida, o $\Delta \Delta \mathrm{Ct}$ foi obtido pela subtração do $\Delta \mathrm{Ct}$ da amostra e o $\Delta \mathrm{Ct}$ da amostra controle e, assim, a fórmula $2^{-\Delta \Delta C t}$ é aplicada. Os resultados obtidos foram expressos em percentuais de expressão.

\subsection{Análise Estatística}

As análises estatísticas foram realizadas com o auxilio do programa GraphPad Prism® v.5.0 (GraphPad Software Inc., California, USA).

Teste de Pearson foi utilizado para estabelecer as correlações entre a idade do diagnóstico e a idade da primeira manifestação clínica e suas variações: a) com ou sem história familiar e b) entre irmãos e não irmãos.

Teste de Mann-Whitney foi utilizado para análise de dados relacionados não pareados, relacionados à idade do diagnóstico e idade da primeira manifestação.

A análise da quantificação relativa da expressão do gene foi realizada utilizando o método $\Delta \Delta \mathrm{Ct}$, conforme descrito no item 4.10.

Em todos os testes os valores de $p$ foram considerados estatisticamente significantes quando menores que 0,05 . 


\section{$5 \quad$ Resultados}

\subsection{Análise da anamnese dos pacientes}

Um total de 33 pacientes de 29 famílias foi analisado quanto à idade da primeira manifestação clínica e a idade do diagnóstico de IDP. A idade atual dos pacientes deste estudo se encontram na faixa de 4 anos a 35 anos (média $15,8 \pm 1,47)$. O gráfico 1 nos mostra que o maior número de pacientes com inicio dos sintomas se concentra antes do $1^{\circ}$ ano de vida e o diagnóstico de IDP irá ocorrer alguns anos mais tarde. Os pacientes tiveram seu diagnóstico em $48 \%$ dos casos entre a idade de 2 a 5 anos, seguido por $43 \%$ em que o diagnóstico foi realizado com idade superior aos cinco anos e apenas $8 \%$ destes pacientes foram diagnosticado nos dois primeiros anos de vida. Dos pacientes onde o primeiro sintoma se iniciou antes de completar um ano de vida, oito deles os sintomas iniciaram antes dos seis meses de idade quando ainda havia níveis de anticorpos maternos transferidos no período gestacional através placenta.

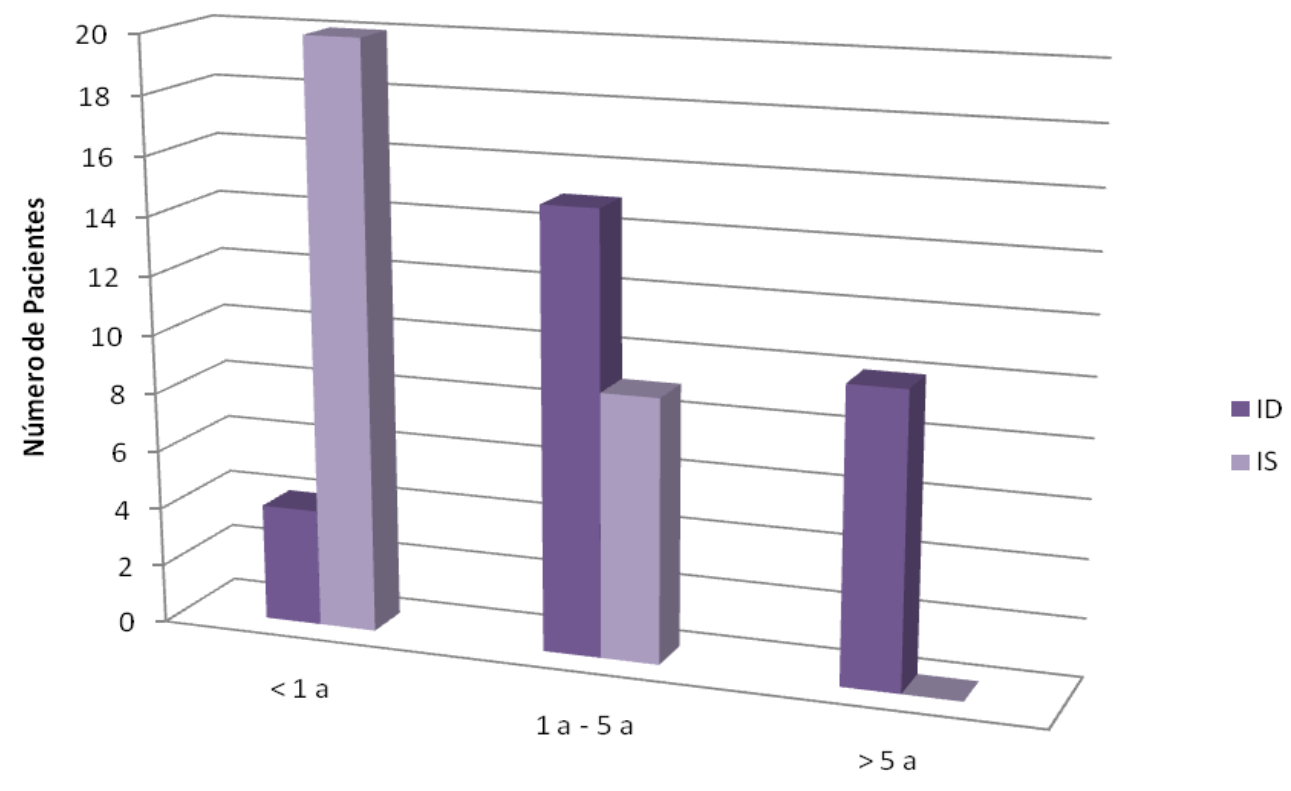

Faixa Etária

Gráfico 1. Distribuição dos pacientes com idade de diagnóstico (ID) e com idade do primeiro sintoma (IS) ao longo da faixa etária - < $1^{\text {a }}$ (menor de 1 ano de idade); 1 a -5 a ( de 1 ano de idade à 5 anos de idade); $>5 \mathrm{a}$ (acima de cinco anos de idade). 


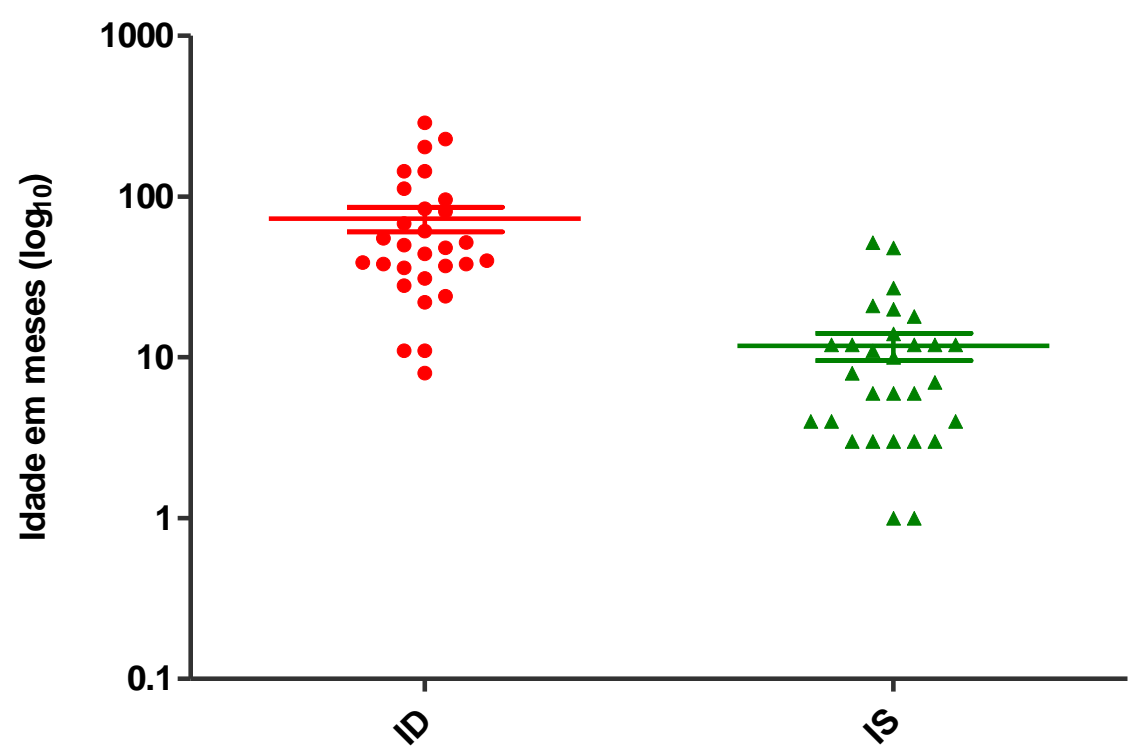

Gráfico 2. Representação da média das idades do diagnóstico da IDP e das idades da primeira manifestação clínica dos pacientes expressa em meses. A média da idade do primeiro sintoma dos pacientes foi de 1 ano $(11,83 \pm 2,30)$ e a média da idade do diagnóstico foi de 60 meses $(73,17 \pm 12,69)$. A relação entre eles foi considerada estatisticamente significante $(p<0,0001)$. [(ID = Idade do Diagnóstico; IS = Idade do Primeiro Sintoma; (Valor da média \pm desvio padrão)].

Ao compararmos a média da idade do primeiro sintoma com a idade do diagnóstico observamos uma média no retardo de diagnóstico em 5 anos $(61,34 \pm 12,89)$.

A idade do diagnóstico e do inicio dos sintomas em pacientes onde a história familiar para IDP é positiva ou onde existe relato de parente com história de infecção de repetição, mas sem uma confirmação precisa de IDP, tiveram média de 5 anos e 1 ano respectivamente $(62,79 \pm 15,08$ e $13,29 \pm 3,42$ respectivamente - valores das médias expressas em meses) consideradas estatisticamente significantes $(p<0,0014)$. E quando comparamos os grupos onde não há relato de história familiar de IDP as médias obtidas foi de 6,5 anos para a idade do diagnóstico $(82,87 \pm 20,29)$ e de 1 ano para $o$ inicio dos sintomas $(10,47 \pm 3,16)(p<0,0001)$. Não observa-se alteração entre as médias de idade do inicio dos sintomas nos dois grupos, porém a idade do diagnóstico é significativamente menor no grupo de história familiar positiva. Comparamos os quatro grupos e obtemos suas médias e a relação de significancia entre elas, e estão descritas na tabela 2. 
Tabela 2. Comparação das idades do diagnóstico e da idade do primeiro sintoma entre os pacientes com história familiar positiva e história familiar negativa de imunodeficiência.

\begin{tabular}{lll}
\hline Relação & Valor de $p$ & Significância \\
\hline ID c/HF+ X IS c/HF+ & $<0,0014$ & Significativo \\
ID c/HF- X IS c/HF- & $<0,0001$ & Significativo \\
ID c/HF+ X ID c/HF- & 0,5125 & Não significativo \\
IS c/HF+ X IS c/HF- & 0,3128 & Não significativo \\
ID c/HF+ X IS c/HF- & $<0,0003$ & Significativo \\
ID c/HF- X IS c/HF+ & $<0,0001$ & Significativo \\
\hline
\end{tabular}

IS (idade do 1 sintoma); ID (idade do diagnóstico); c/HF+ (com história familiar); c/HF(sem história familiar); X (comparado); Teste não paramétrico Mann-Whitney.

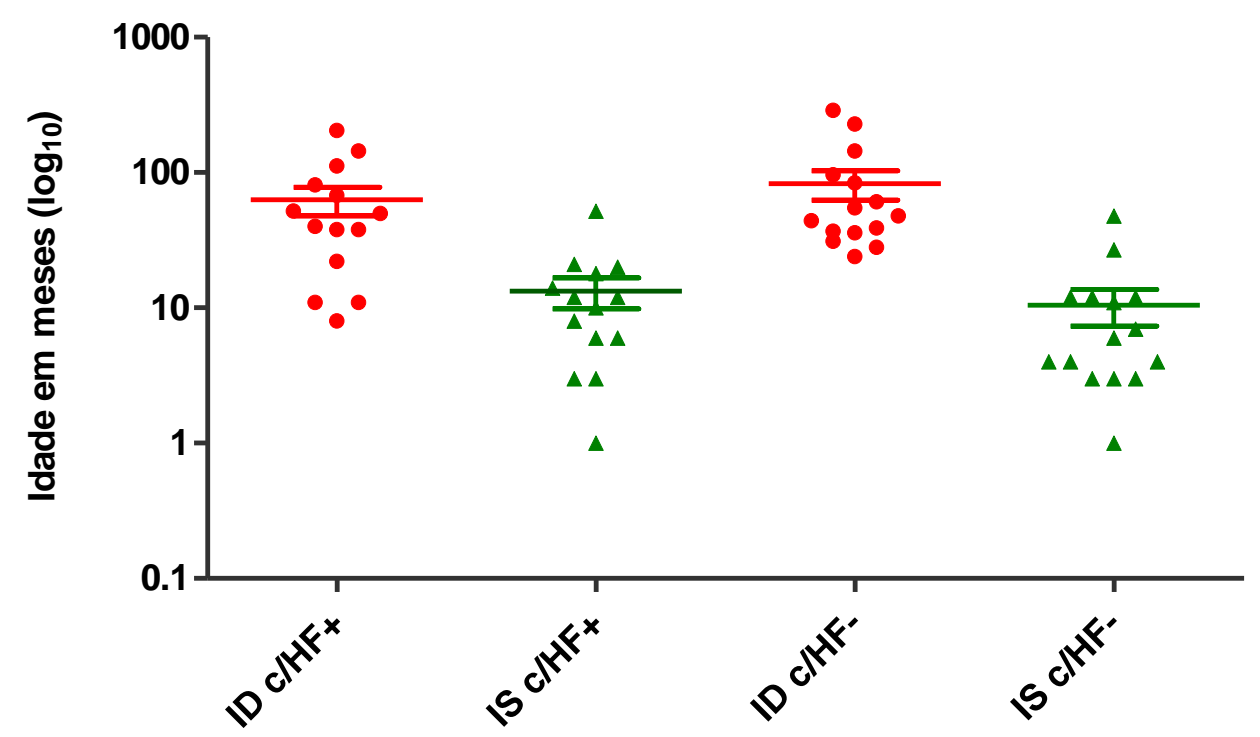

Gráfico 3. Comparação da idade do $1^{\circ}$ sintoma (IS) e da idade do diagnóstico (ID) dos pacientes com história familiar (c/HF+) e sem história familiar (c/HF-) de imunodeficiência. A média do grupo ID c/HF+ foi de $62,79 \pm 15,08$ e do grupo IS $c / H F+$ foi de $13,29 \pm 3,42 \quad(p<0,0014)$. Entre os grupos ID s/HF- e IS s/HF- as médias foram de $82,87 \pm 20,29$ e $10,47 \pm 3,16$ $(p<0,0001)$. A comparação entre os grupos ID $c / H F+$ e s/HF- não foi significante $(p=0,5125)$ e o mesmo ocorreu entre os grupos IS c/HF+e s/HF+ $(p=0,3128)$.

A análise dos grupos com história familiar de IDP foi analisada sobre dois aspectos: o grupo de famílias com irmãos (IR) e o grupo de famílias de pacientes únicos (NIR). Os dados mostram que com relação a idade do diagnóstico (ID) entre estes dois grupos foi de $31 \pm 7,642$ e $91,8 \pm 16,63$ respectivamente e sua relação foi considerado significativo $(p<0,0118)$. Quando comparamos a idade do primeiro sintoma (IS) entre esses grupos, a relação não foi considerada significante 
( $\mathrm{p}=05059$ ) e suas médias foram de $7,875 \pm 2,150$ para o grupo de irmãos e $12,95 \pm 3,16$ para o grupo de parentes únicos, confirmando a independência da manifestação da doença.

Interessantemente, quando realizamos as diferentes análises, relacionadas na tabela 3 , entre os quatro grupos, observamos que existe significância entre os grupos, com exceção do inicio dos sintomas entre os grupos de irmãos ou não.

Tabela 3. Relação estatísticas das idades do diagnóstico e das idades do primeiro sintoma entre os pacientes irmãos e de pacientes únicos (não irmãos) no grupo com história familiar positiva de IDP.

\begin{tabular}{ccc}
\hline Relação & Valor de $p$ & Significância \\
\hline ID-IR X IS-IR & $<0,018$ & Significativo \\
\hline ID-NIR X IS-NIR & $<0,0001$ & Significativo \\
\hline ID-IR X ID-NIR & $<0,0118$ & Significativo \\
IS-IR X IS-NIR & 0,5059 & Não significativo \\
ID-IR X IS-NIR & $<0,0252$ & Significativo \\
ID-NIR X IS-IR & $<0,0001$ & Significativo \\
\hline
\end{tabular}

IS (idade do 1 ำ sintoma); ID (idade do diagnóstico); IR (Irmãos); NIR (Não Irmãos); X (comparado). Teste não paramétrico Mann-Whitney. 


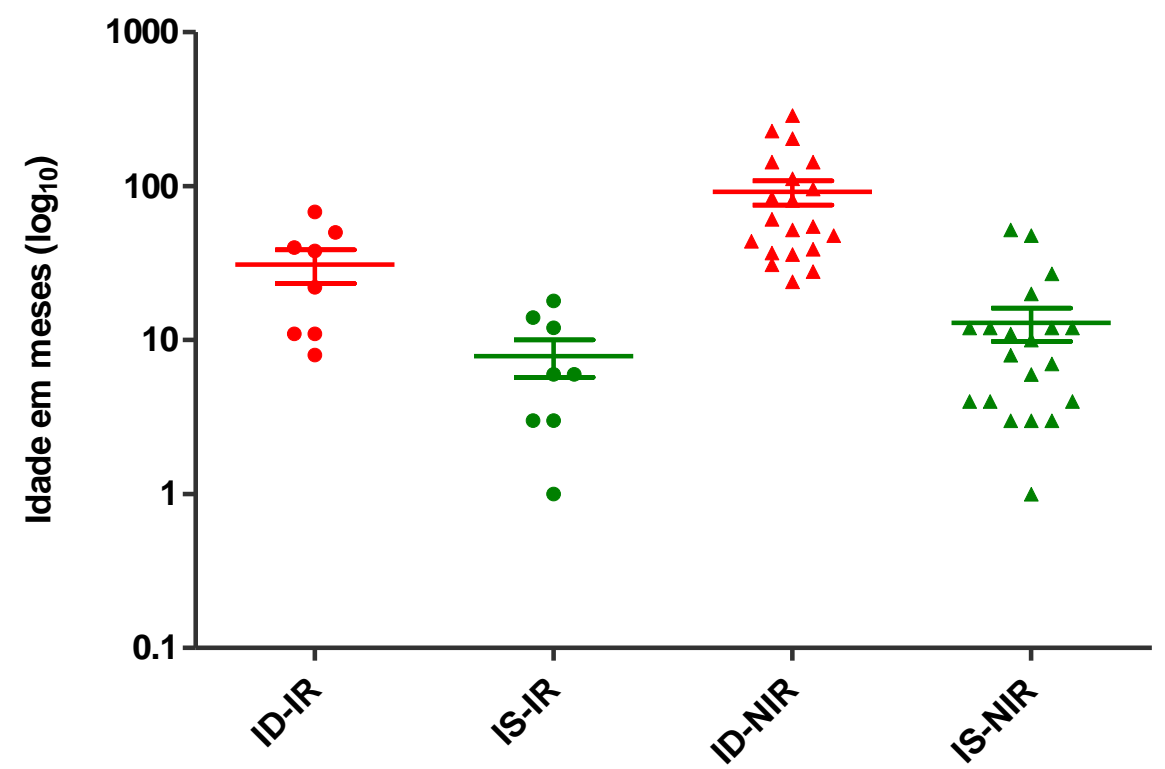

Gráfico 4. Comparação das idades do diagnóstico (ID) e das idades do primeiro sintoma (IS) entre os pacientes irmãos (IR) e de pacientes únicos - não irmãos - (NIR). Para o grupo entre irmãos a média da idade do diagnóstico (ID-IR) foi de $31 \pm 7,642$ e do inicio do primeiro sintoma (IS-IR) foi de $13,29 \pm 3,42 \quad(p<0,0018)$. Entre o grupo de pacientes únicos (não irmãos) as médias para idade do diagnóstico (ID-NIR) e do inicio dos sintomas (IS-NIR) foram de $91,80 \pm 16,63$ e $12,95 \pm 3,16(p<0,0001)$. As diferença entre os grupos ID-IR e IDNIR foi significante $(p<0,0118)$ e entre os grupos IS-IR e IS-NIR foi insignificante $(p=0,5059)$. As demais relações entre os grupos tiveram valores de $p$ significativos (tabela 3).

\subsection{Manifestações Clínicas}

As infecções respiratórias foram as mais freqüentes acometendo quase a totalidade dos pacientes. As infecções respiratórias superiores representaram $60 \%$ das manifestações, representadas pelas otites (OMA), sinusites, IVAS (infecções das vias áreas superiores) e pneumonias. Observou-se um número significativo de pacientes que desenvolveram diarréia e um pequeno número diagnosticado com diarréia crônica (3 pacientes). As meningites, sepses e infecções cutâneas apresentaram menor freqüência.

Foi relatado um óbito dentre o grupo. O paciente apresentou, além das infecções mais comuns relatadas para XLA, positividade nas fezes para poliovirus e bronquiectasias. 
A maioria dos agentes microbianos causadores destas infecções não foram identificados, pois de uma maneira geral, os serviços de saúde não têm em sua rotina $\mathrm{o}$ isolamento destes microorganismos.

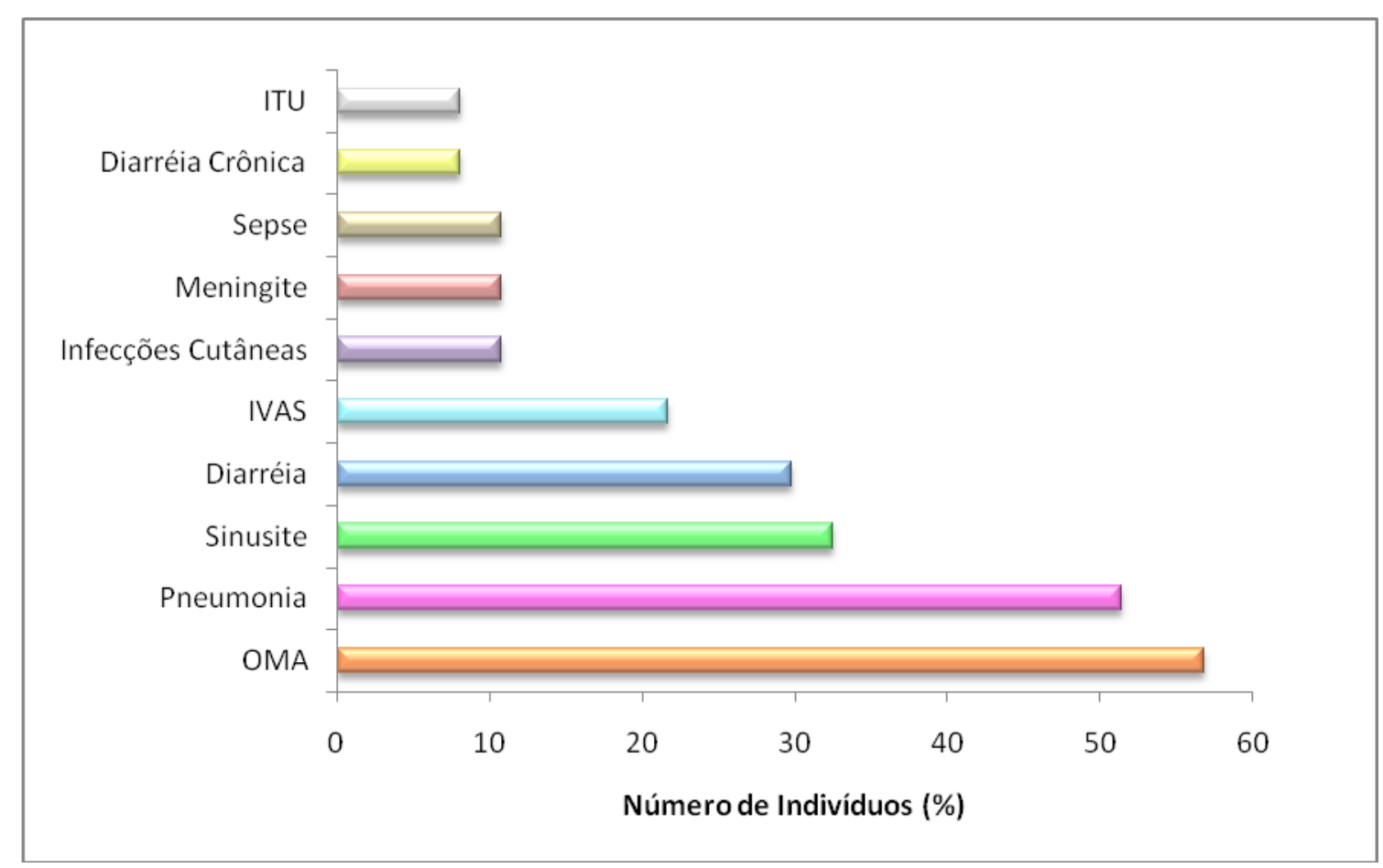

Gráfico 5. Freqüência das principais manifestações clínicas dos pacientes com XLA estudados. ITU (infecção do trato urinário); IVAS (infecção das vias aéreas superior); OMA (otite média aguda).

\subsection{História Familiar}

Foram incluídos no grupo de história familiar positiva todos os pacientes com algum relato história familiar positiva de infecção grave e/ou de repetição, , morte por infecção. Levou-se em consideração que os diagnósticos de IDP no Brasil datam de inicio recente e há alguns anos atrás este diagnóstico estava restrito apenas a alguns centros de referência. Com isto este dado ainda é passível de alteração devido a dificuldade de levantamento das informações de gerações passadas.

$\mathrm{O}$ índice dos pacientes que participam deste estudo com alguma história familiar positiva foi de $40 \%$. Todos os relatos foram considerados e os dados coletados dos pacientes quanto à história Familiar e a identificação de cada paciente se encontram no Anexo IV. 


\subsection{Níveis das Imunoglobulinas no Diagnóstico da IDP}

Os pacientes que integram este estudo foram analisados quanto às dosagens das imunoglobulinas G, M e A pelo método de Nefelometria, na ocasião do diagnóstico da IDP e, as dosagens subseqüentes, foram realizadas antes, ou em alguns casos posterior, ao paciente iniciar o tratamento de reposição de imunoglobulina humana. Os gráficos a seguir trazem o perfil dos níveis das imunoglobulinas comparados às curvas de normalidade para a população brasileira, segundo estudo de Fujimura (1990).

\subsubsection{Imunoglobulinas G}

As dosagens das Imunoglobulinas $G$ dos pacientes deste estudo antes do diagnóstico foram inferior ao percentil 3 para a faixa etária (Gráfico 6). Embora a maioria deles tivesse nível de lgG inferior a $200 \mathrm{mg} / \mathrm{dl}$, alguns pacientes apresentavam níveis da IgG elevados embora abaixo do percentil 3 (p12 $597 \mathrm{mg} / \mathrm{dl}$; p21- $438 \mathrm{mg} / \mathrm{dl}$; p25 - $539 \mathrm{mg} / \mathrm{dl} ;$ p34 - $496 \mathrm{mg} / \mathrm{dl}$ e p36 - $360 \mathrm{mg} / \mathrm{dl}$ ), porém a dosagem de todos estes pacientes foram realizadas em idade adulta e estavam em uso de imunoglobulina humana, , com exceção do p34 e p36 que a dosagem foi realizada na faixa etária de 12 anos de idade. Entretanto, embora sejam considerados altos valores obtidos destas dosagens, eles se apresentaram inferiores ao percentil 3 para a faixa etária. idade. 


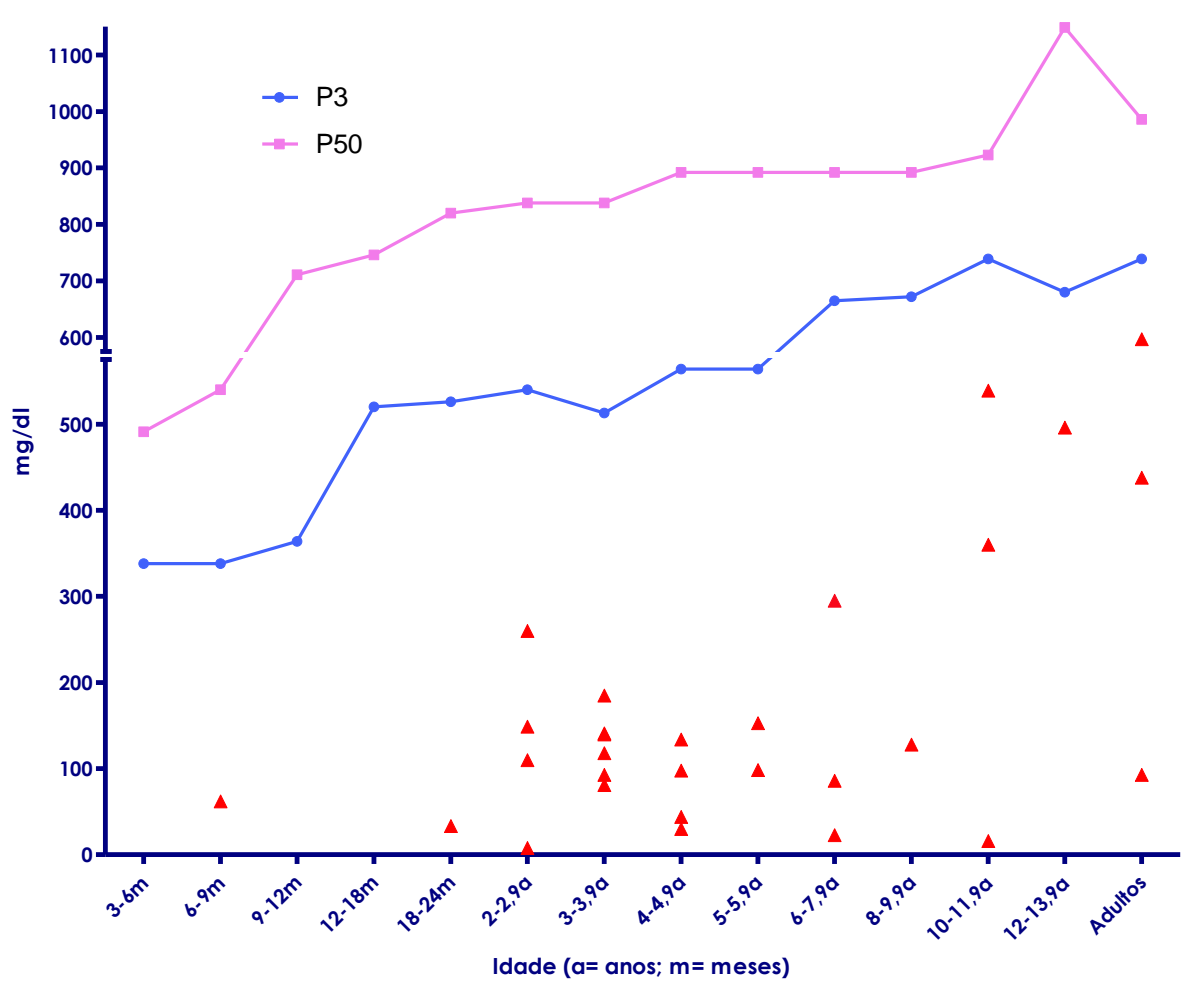

Gráfico 6. Níveis da imunoglobulina $\mathrm{G}$ dos pacientes no momento do diagnóstico e antes do inicio da terapia de reposição com imunoglobulina humana, comparados aos valores normais para a faixa etária (Fujimura MD, 1990).

\subsubsection{Imunoglobulinas M}

A análise dos dados apresenta um paciente com nível de IgM com valores normais para a faixa etária, compreendendo entre o percentil 3 e o percentil 50 (p6 $79 \mathrm{mg} / \mathrm{dl}$ ). Também observou-se pacientes com valores para imunoglobulina $\mathrm{M}$ no limiar inferior próximo ao percentil 3 (p15 - $34 \mathrm{mg} / \mathrm{dl}$; p28 - $40 \mathrm{mg} / \mathrm{dl}$ e p24 - 37 $\mathrm{mg} / \mathrm{dl})$. Novas dosagens de IgM foram realizadas em diferentes tempos e os níveis e se mantiveram entre $7-18 \mathrm{mg} / \mathrm{dl}$, ficando abaixo da curva do percentil 3 para a faixa etária, a exceção dos pacientes p6 e p15 que apresentaram oscilações ao longo das dosagens.

No gráfico 7 observamos o perfil das dosagens da imunoglobulina $M$ nos pacientes e a relação com os valores de normalidade para a faixa etária. 


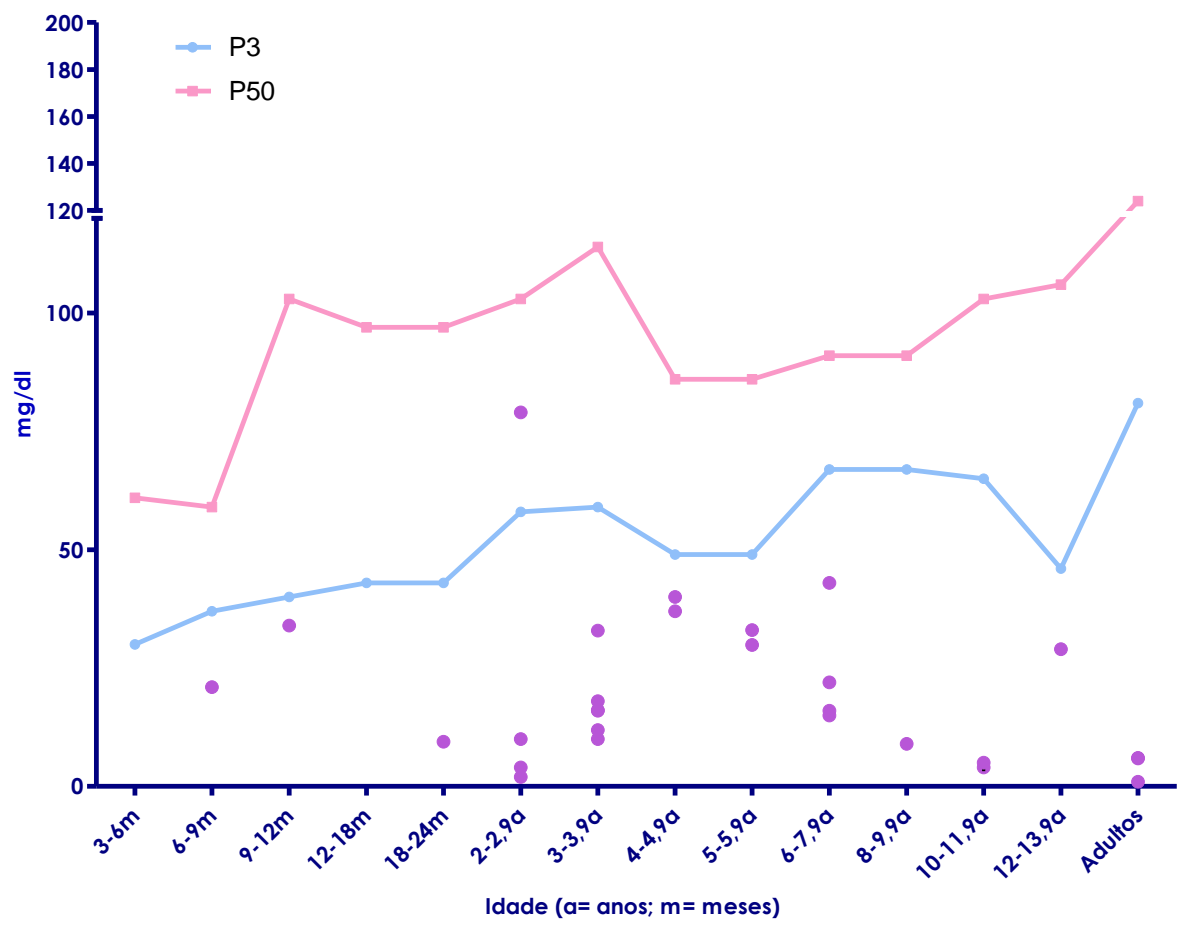

Gráfico 7. Níveis da imunoglobulina $M$ no momento do diagnóstico dos pacientes e anteriores ao inicio da terapia de reposição com imunoglobulina humana. Valores comparados com curva de normalidade (P3 e P50) para a faixa etária (Fujimura, MD. 1990).

\subsubsection{Imunoglobulinas A}

O perfil das dosagens das imunoglobulinas $A$ dos pacientes em comparação com as curvas de valores de normalidade para a faixa etária (gráfico 8). A análise dos dados nos mostra um paciente com nível elevado de imunoglobulina A (p34 $389 \mathrm{mg} / \mathrm{dl}$ ). Três pacientes apresentaram níveis de IgA entre o P3 e P50 para a faixa etária (p12 - $131 \mathrm{mg} / \mathrm{dl} ; \mathrm{p} 15-27 \mathrm{mg} / \mathrm{dl}$ e p5 - $22 \mathrm{mg} / \mathrm{dl}$ ) e dois paciente apresentaram valor da IgA no limiar do percentil 3 (p6 - $29 \mathrm{mg} / \mathrm{dl}$; $p 9-42 \mathrm{mg} / \mathrm{dl})$ ). 


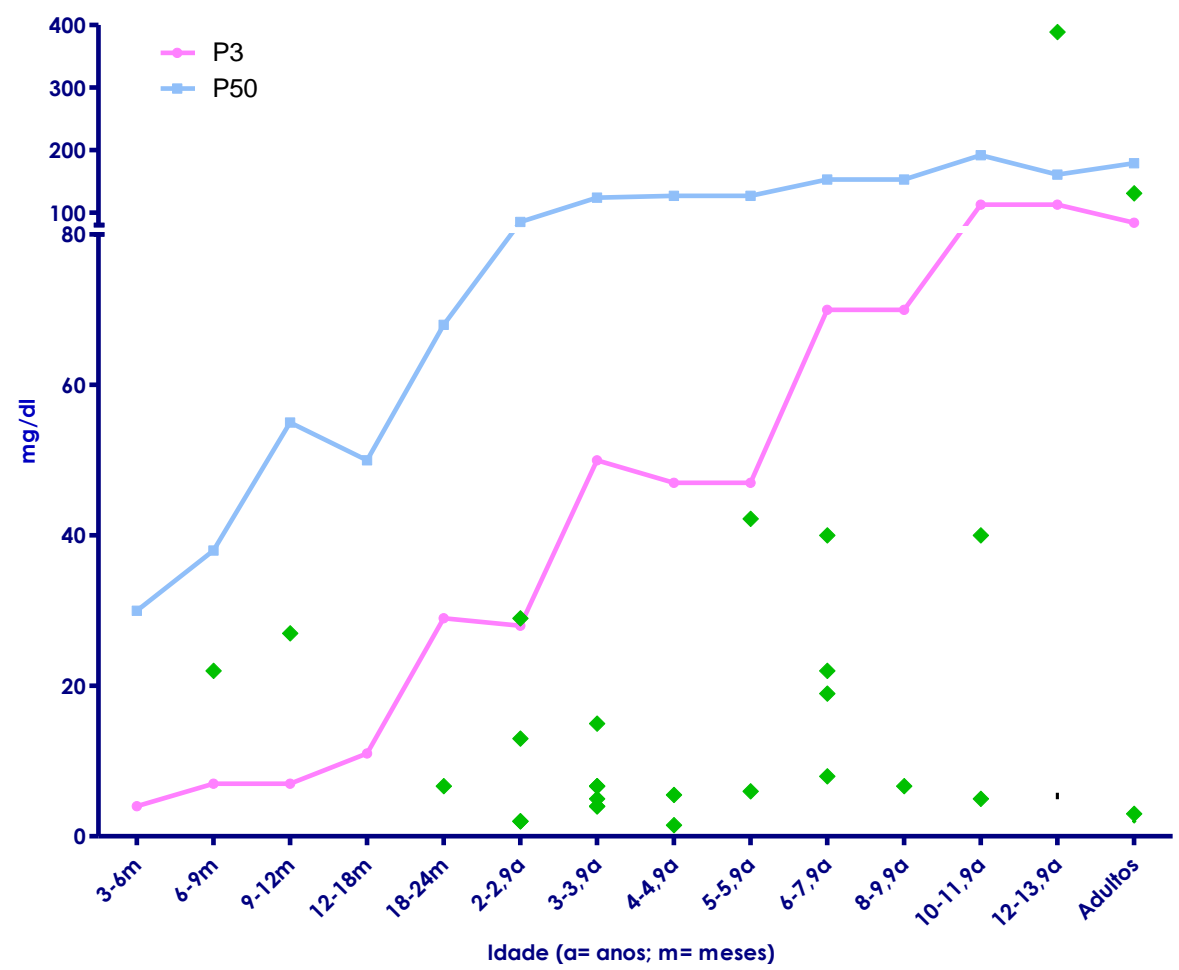

Gráfico 8. Níveis da imunoglobulina A no grupo dos pacientes no momento do diagnóstico e antes do inicio da terapia de reposição com imunoglobulina humana. Valores comparados com curva de normalidade (P3 e P50) para a faixa etária (Fujimura, MD. 1990).

\subsection{Concentrações de Células B em Sangue Periférico}

As percentagens de células de todos os pacientes que integram este estudo apresentaram níveis inferiores a $2 \%$, com percentual de $60 \%$ dos pacientes com níveis indetectáveis de células $\mathrm{B}$ em sangue periférico. Demais pacientes oscilaram entre $0,6 \%$ a $1 \%$. Um paciente (p37) apresentou níveis de 8,4\% (por definição é ICV) de células $B$ em sangue periférico, entretanto as dosagens dos isotipos das Imunoglobulinas demonstrou que os valores se encontram nos limites inferiores ao percentil 3 da curva de valores normais para a população brasileira e com níveis normais para as células CD3, CD4, CD8 e NK. 


\subsection{Resultados da Análise dos Exons do Gene btk por SSCP/HA}

Utilizou-se o método de SSCP/HA como técnica de triagem para detecção de mutações nos exons do gene da btk, seguindo-se do seqüenciamento das regiões alteradas, procedeu-se a análise dos 33 pacientes e 12 controles para os 19 exons do gene incluindo as regiões de splicing.

A técnica de SSCP/HA foi escolhida por ser uma técnica de fácil manuseio, reprodutível e baixo custo e bem relatada como método preferencial de triagem de mutações na literatura (Conley et al.,2005). A especificidade do método é de $70 \%$, porém a associação da análise em duas temperaturas e utilizando o padrão de heteroduplex aumentam sua especificidade.

Devido à heterogeneidade de mutações ao longo de todo o gene da btk, não foi possível selecionarmos pontos de hot spot para iniciarmos nossa análise, procedeu-se o screening em todos os exons em todos os pacientes e controles.

As figuras abaixo demonstram as alterações eletroforéticas encontradas nos pacientes. Todos os exons com alterações foram sequenciados para confirmação ou não da mutação.

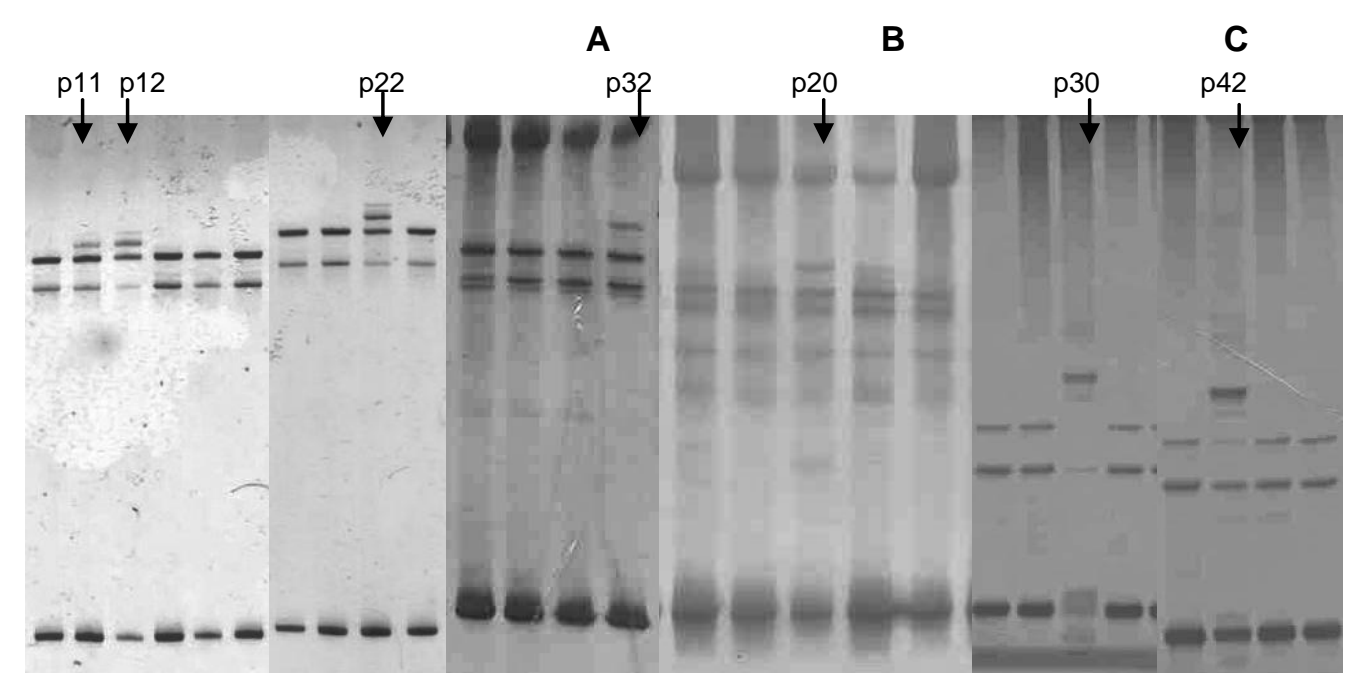

Figura 6. Figuras das alterações na corrida eletroforética encontradas nos pacientes e que foram submetidas ao seqüenciamento. As setas indicam o paciente que apresentou o padrão eletroforético diferenciado em relação às demais amostras e aos controles. A) Exon 2: Pacientes p11, p12, p22 e p32; B) Exon 4: Paciente p20; C) Exon 5: Pacientes p30 e p42; D) Exon 7: Paciente p32; E) Exon 9: Pacientes p1, p2, p4, p7, p18, p25 e p29; F) Exon 11: Pacientes p27, p32 e p37; G) Exon 12: Pacientes p30, p33 e p34; H) Exon 16: Pacientes p9; p26 e p36; I) Exon 17: Pacientes p21, p28 e p31; J) Exon 18: Pacientes p5, p6, p15, p16 e p23. 
D

$\mathbf{E}$

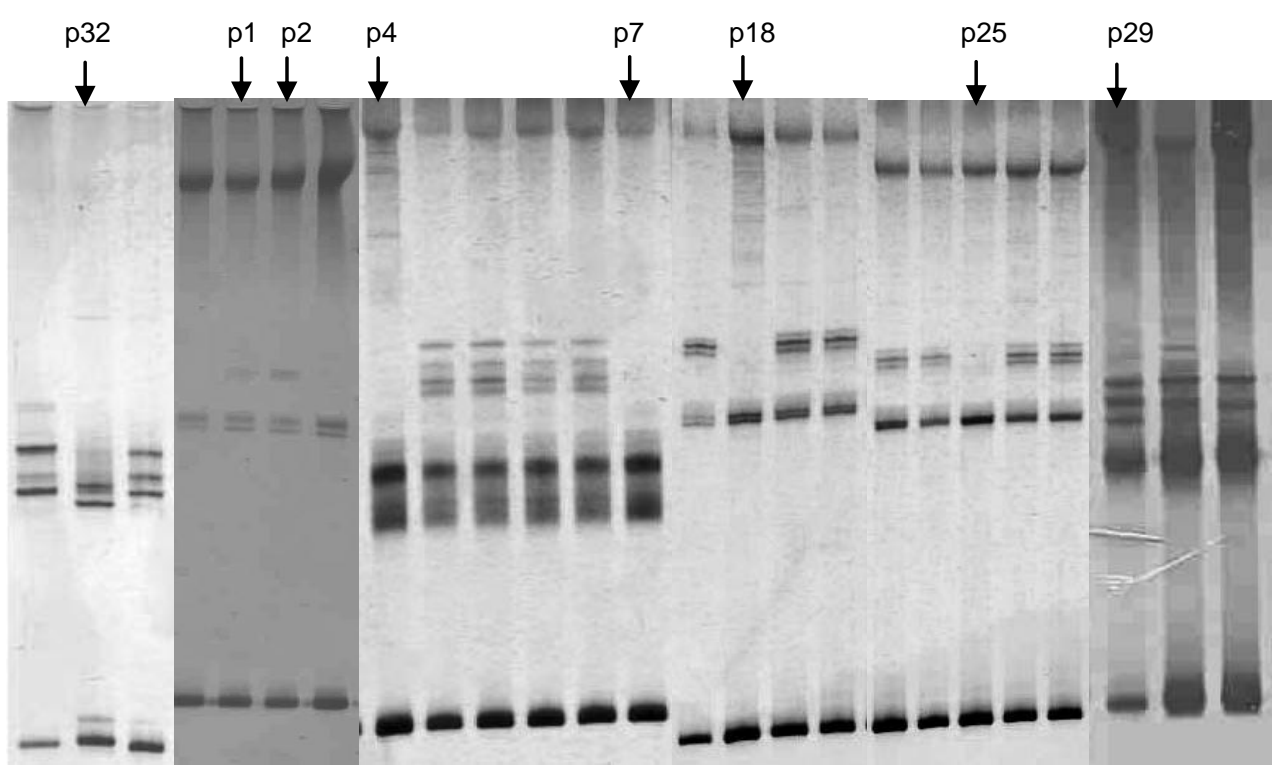

$\mathbf{F}$ G

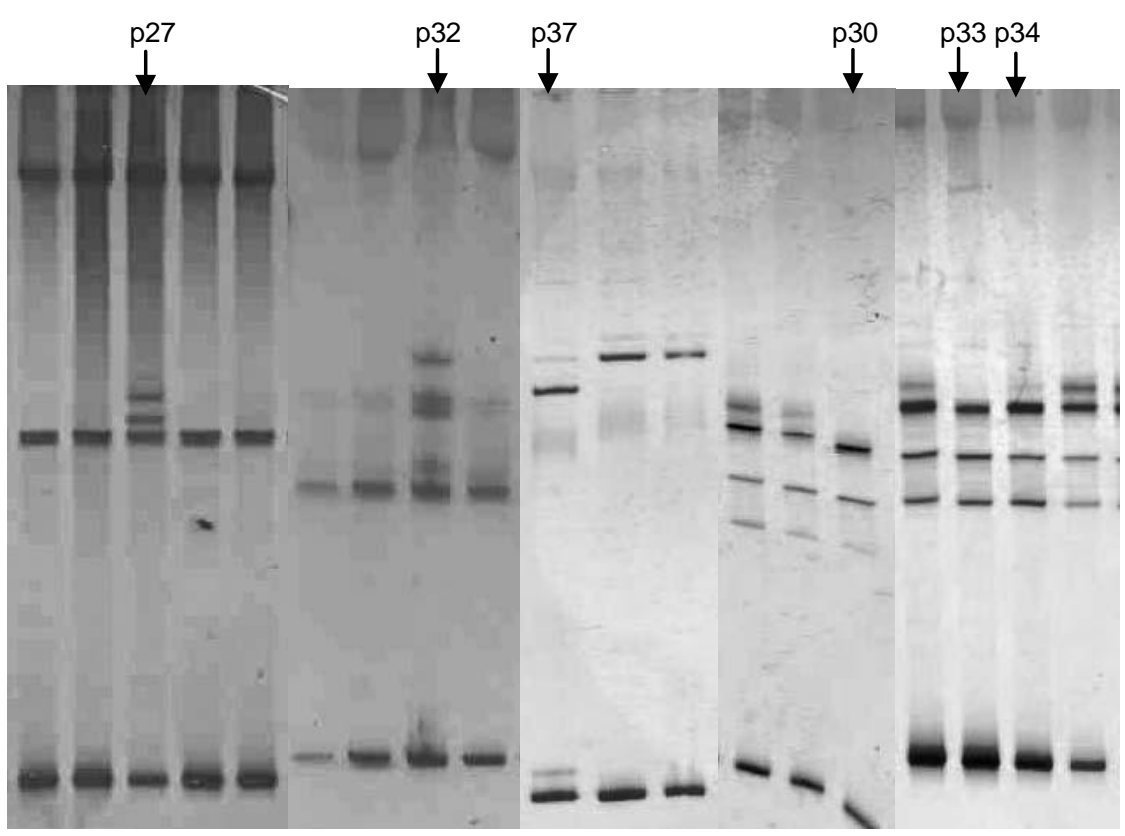

Figura 6. Figuras das alterações na corrida eletroforética encontradas nos pacientes e que foram submetidas ao seqüenciamento. As setas indicam o paciente que apresentou o padrão eletroforético diferenciado em relação às demais amostras e aos controles. A) Exon 2: Pacientes p11, p12, p22 e p32; B) Exon 4: Paciente p20; C) Exon 5: Pacientes p30 e p42; D) Exon 7: Paciente p32; E) Exon 9: Pacientes p1, p2, p4, p7, p18, p25 e p29; F) Exon 11: Pacientes p27, p32 e p37; G) Exon 12: Pacientes p30, p33 e p34; H) Exon 16: Pacientes p9; p26 e p36; I) Exon 17: Pacientes p21, p28 e p31; J) Exon 18: Pacientes p5, p6, p15, p16 e p23. 

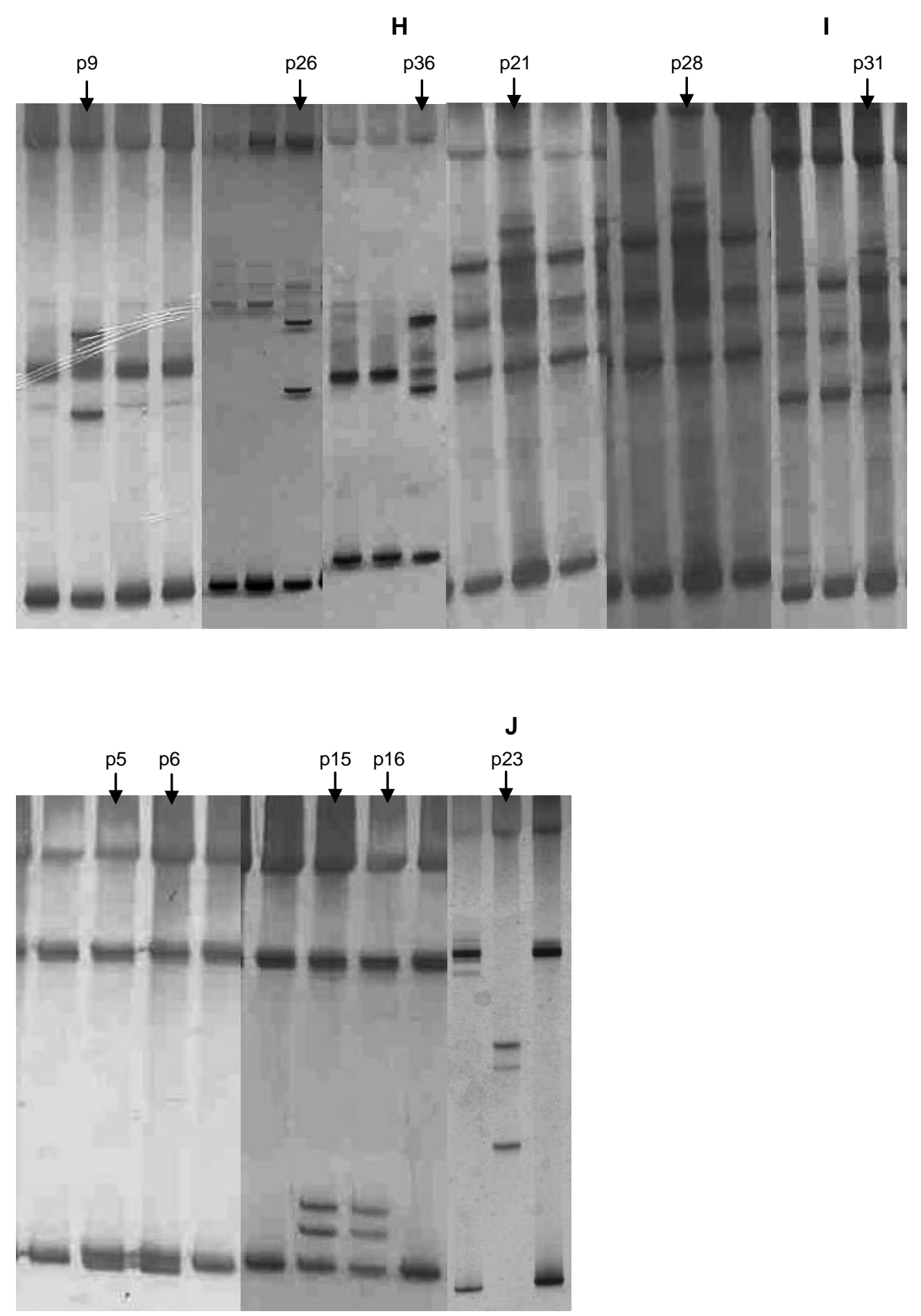

Figura 6. Figuras das alterações na corrida eletroforética encontradas nos pacientes e que foram submetidas ao seqüenciamento. As setas indicam o paciente que apresentou o padrão eletroforético diferenciado em relação às demais amostras e aos controles. A) Exon 2: Pacientes p11, p12, p22 e p32; B) Exon 4: Paciente p20; C) Exon 5: Pacientes p30 e p42; D) Exon 7: Paciente p32; E) Exon 9: Pacientes p1, p2, p4, p7, p18, p25 e p29; F) Exon 11: Pacientes p27, p32 e p37; G) Exon 12: Pacientes p30, p33 e p34; H) Exon 16: Pacientes p9; p26 e p36; I) Exon 17: Pacientes p21, p28 e p31; J) Exon 18: Pacientes p5, p6, p15, p16 e p23. 


\subsection{Análise dos Seqüenciamentos}

Todas as amostras que apresentaram padrão de corrida eletroforética diferenciado na técnica de SSCP/HA foram submetidas ao seqüenciamento e a análise foi realizada confrontando a seqüência obtida com a seqüência referência depositada no banco internacional de genomas - GenBank, utilizando o programa Blast (Basic Local Alignment Tool) do National Center For Biotechnology Information (NCBI) com o auxílio do editor de seqüências biológicas BioEdit (Ibis Therapeutics Carlsbad, CA, EUA).

As seqüencias referência utilizadas foram: DNA genômico gi:2281904/locus HSU78027; DNA complementar gi:455376/NM000061.

Das mutações detectadas $58 \%$ delas foram mutações de substituição de uma base e tendo como conseqüência a troca de aminoácidos; 35\% foram de mutações de deleções de uma base ou mutações de inserções de uma base gerando um stop códon prematuro e 7\% das mutações foram nas regiões de sitio de splicing afetando os domínios PH; SH3 e SH1 (Quinase) e a estrutura primária do RNA. A tabela 4 traz a relação das mutações encontradas e suas conseqüências e as localizações das mutações nos domínios da proteína estão esquematizadas na figura 7 . Os cromatogramas destas mutações estão relacionadas no anexo. 


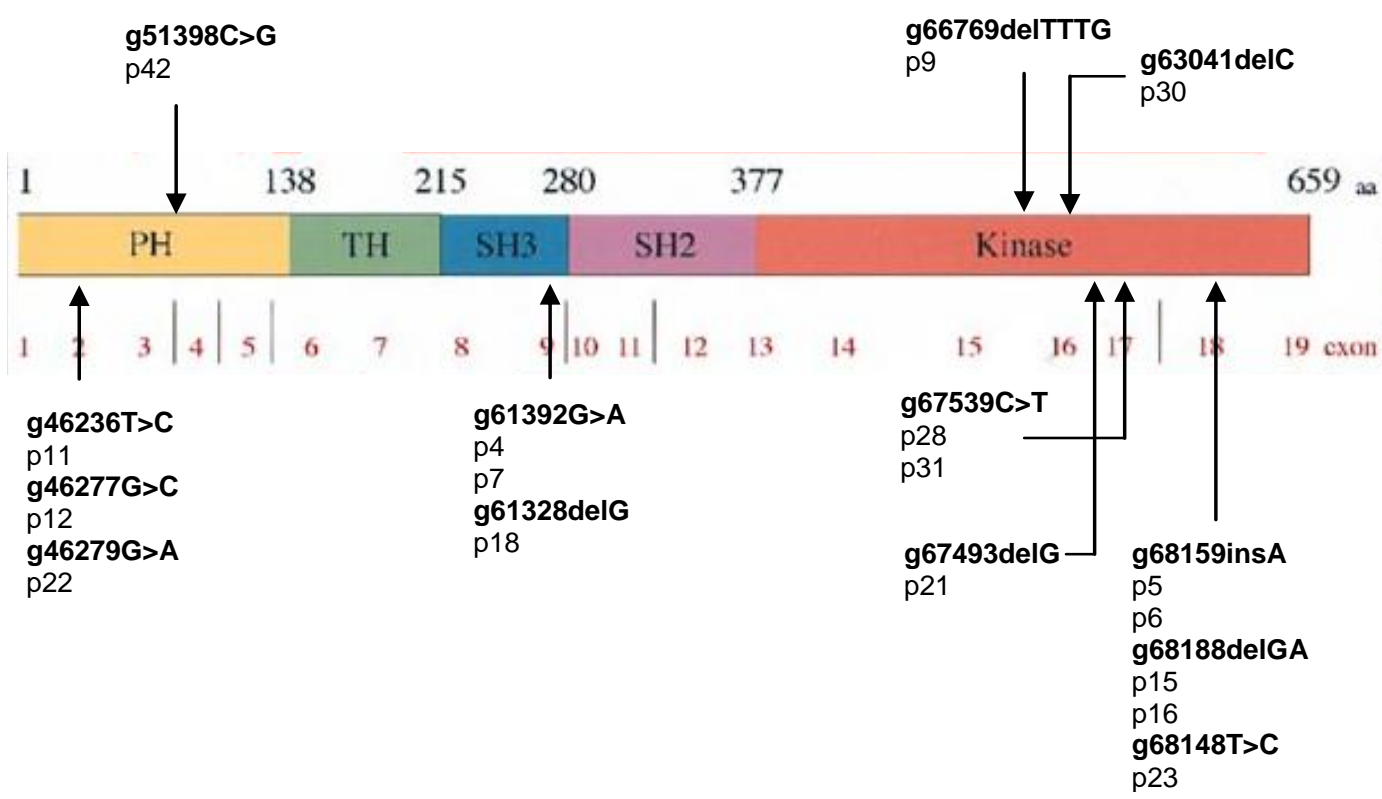

Figura 7. Esquema da distribuição das mutações descritas neste estudo, ao longo dos domínios da proteína BTK. 
Tabela 4. Relação das mutações encontradas em cada paciente e suas conseqüências:

\begin{tabular}{|c|c|c|c|c|c|c|c|}
\hline № & Sigla & & utações & & Exon & Dominio & Consequência \\
\hline & & gDNA & cDNA & Proteina & & & \\
\hline 4 & LSJ & $g 61392 G>A$ & & & Exon 9 & $\mathrm{SH} 3$ & sitio de splicing \\
\hline 5 & $\mathrm{NMH}$ & g68159insA & c1948insA & pE598X & Exon 18 & Kinase & stop codon \\
\hline 6 & HMN & g68159insA & c1948insA & pE598X & Exon 18 & Kinase & stop codon \\
\hline 7 & PRSJ & $g 61392 G>A$ & & & Exon 9 & $\mathrm{SH} 3$ & sitio de splicing \\
\hline 9 & RSB & g66769delTTTG & & & Intron 15 & Kinase & sitio de splicing \\
\hline 11 & JVCM & g46236T >C & c203T>C & pS14P & Exon 2 & $\mathrm{PH}$ & Troca de aminoácidos \\
\hline 12 & GSP & g46277G>C & $c 244 G>C$ & pK27N & Exon 2 & $\mathrm{PH}$ & Troca de aminoácidos \\
\hline 15 & CFM & g68188delGA & c1946delGA & pA607X & Exon 18 & Kinase & stop codon \\
\hline 16 & EFM & g68188delGA & c1946delGA & pA607X & Exon 18 & Kinase & stop codon \\
\hline 18 & NGV & g61328delG & c917delG & & Exon 9 & $\mathrm{SH} 3$ & stop codon \\
\hline 21 & SAR & g67493delG & & & Intron 16 & Kinase & sitio de splicing \\
\hline 22 & AHPF & $g 46279 G>A$ & $c 246 A>G$ & $\mathrm{pR} 28 \mathrm{H}$ & Exon 2 & $\mathrm{PH}$ & Troca de aminoácidos \\
\hline 23 & RNA & g68148T>C & c1899T>C & pS590P & Exon 18 & Kinase & Troca de aminoácidos \\
\hline 26 & VVC & $g 66787 \mathrm{C}>\mathrm{T}$ & $c 1736 \mathrm{C}>\mathrm{T}$ & pR525X & Exon 16 & Kinase & stop codon \\
\hline 28 & FLD & $g 67539 \mathrm{C}>\mathrm{T}$ & $c 1847 C>T$ & pR562W & Exon 17 & Kinase & Troca de aminoácidos \\
\hline 30 & LPM & g63041delC & c1138delC & pD326G & Exon 12 & $\mathrm{SH} 2$ & Alteração frameshift \\
\hline 31 & ECM & $g 67539 \mathrm{C}>\mathrm{T}$ & $\mathrm{c} 1847 \mathrm{C}>\mathrm{T}$ & pR562W & Exon 17 & Kinase & Troca de aminoácidos \\
\hline 42 & NGPA & g51398C>G & & & Intron 4 & $\mathrm{PH}$ & sitio de splicing \\
\hline
\end{tabular}

Irmãos: Paciente 4 e 7; 5 e 6; 15 e 16;

g - DNA genômico; c - DNA complementar; $p$ - Proteína.

\subsection{Análise da expressão do gene Btk através de Real-Time-PCR}

As amostras dos pacientes foram submetidas a análise de expressão relativa para o gene btk através da técnica de Real-Time. Os dados obtidos mostram a qualidade da reação, tanto do gene alvo quanto do gene controle, pelas 
características da curva de dissociação, onde se observa a ausência de dímeros de primers e de amplificações inespecíficas (figura 7 e 8).

A

B

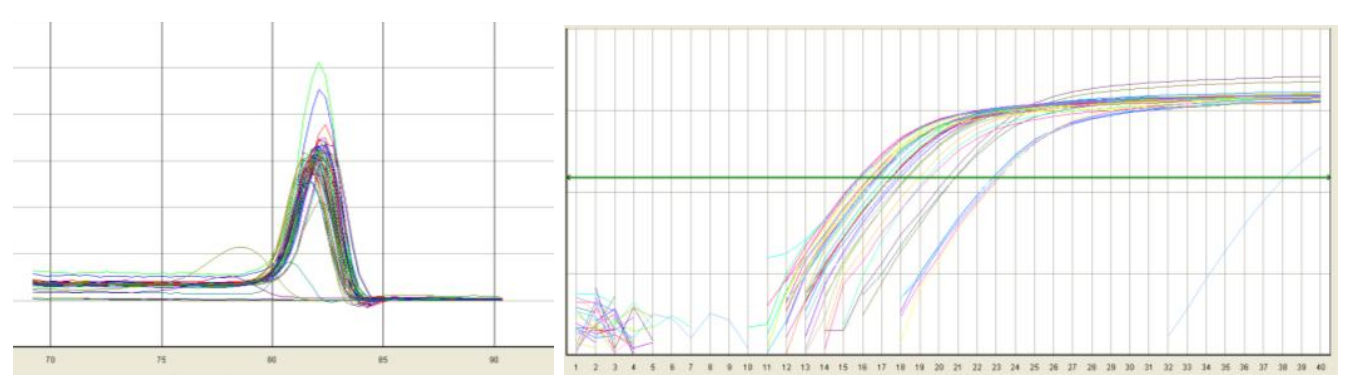

Figura 8. Curva de dissociação (A) e de amplificação (B) do primer do gene controle $\beta$-actina.

A

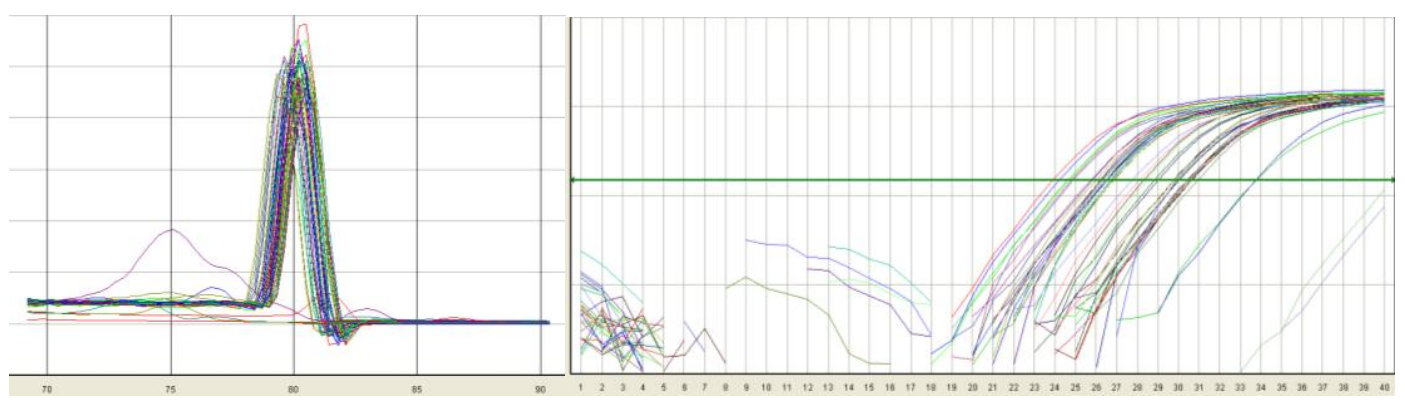

Figura 9. Curva de dissociação (A) e de amplificação (B) com o primer do gene alvo Btk.

O resultado da expressão através do método $2^{-\Delta \Delta C t}$ das amostras apresentou uma redução significativa da expressão do gene Btk nos pacientes onde as mutações geraram stop codon prematuro; em um paciente a expressão teve níveis de expressão em $60 \%$; cinco pacientes a expressão ficou em média $25 \%$, dois destes pacientes a mutação não foi identificada, outros dois a mutação foi no sitio de splicing e um a mutação foi a troca de um aminoácido no dominio kinase da proteína.

As demais amostras, onde encontramos, além de stop codon, mutações em sitio de splicing; troca de aminoácidos e alteração de frameshift. 


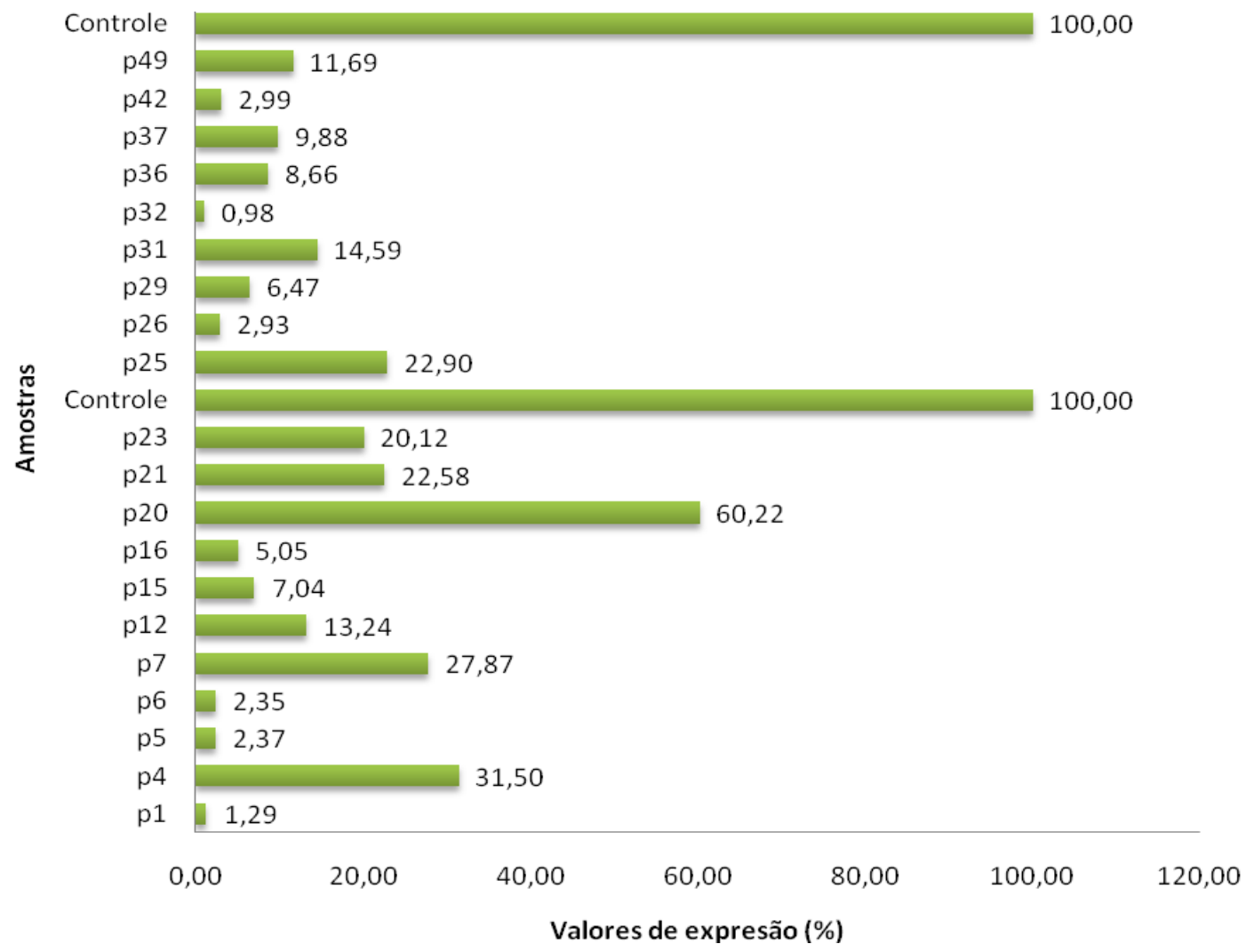

Gráfico 9. Valores das expressões do gene Btk expressos em percentual, após análise pelo método $2^{-\Delta \Delta C t}$. As expressões $100 \%$ são das amostras controles; 1 amostra apresentou altos níveis de expressão (60\%); 5 amostras o valor da expressão foi em média de $25 \%$; e as demais amostras (66\%) os níveis de expressão não ultrapassaram $15 \%$. 
Tabela 5. Dados da análise da expressão do gene Btk obtidas pela técnica real-time quantitativa relativa. Os valores de $\mathrm{Ct}$ (threshold) foram obtidos como resultado da leitura das amostras pelo equipamento.

\begin{tabular}{|c|c|c|c|c|c|c|}
\hline & CT Btk & $\begin{array}{l}\text { CT } \beta- \\
\text { actina }\end{array}$ & $\Delta \mathrm{Ct}$ & $\Delta \Delta \mathrm{Ct}$ & $2^{-\Delta \Delta C t}$ & $\%$ \\
\hline $\mathrm{p} 1$ & 34,935 & 21,787 & 13,148 & 6,278 & 0,013 & 1,29 \\
\hline p2 & 31,953 & 18,010 & 13,943 & 7,713 & 0,005 & 0,476 \\
\hline p4 & 25,917 & 17,380 & 8,537 & 1,667 & 0,315 & 31,50 \\
\hline p5 & 31,780 & 19,513 & 12,267 & 5,397 & 0,024 & 2,37 \\
\hline p6 & 31,007 & 18,725 & 12,282 & 5,412 & 0,023 & 2,35 \\
\hline p7 & 27,173 & 18,460 & 8,713 & 1,843 & 0,279 & 27,87 \\
\hline p12 & 27,610 & 17,823 & 9,787 & 2,917 & 0,132 & 13,24 \\
\hline p15 & 28,457 & 17,758 & 10,699 & 3,829 & 0,070 & 7,04 \\
\hline p16 & 29,321 & 18,143 & 11,178 & 4,308 & 0,050 & 5,05 \\
\hline p20 & 31,667 & 24,065 & 7,602 & 0,732 & 0,602 & 60,22 \\
\hline p21 & 27,743 & 18,727 & 9,017 & 2,147 & 0,226 & 22,58 \\
\hline p23 & 27,183 & 18,000 & 9,183 & 2,313 & 0,201 & 20,12 \\
\hline Controle & 31,083 & 24,213 & 6,870 & 0,000 & 1,000 & 100,00 \\
\hline p25 & 35,560 & 27,173 & 8,387 & 2,127 & 0,229 & 22,90 \\
\hline p26 & 29,210 & 17,857 & 11,353 & 5,093 & 0,029 & 2,93 \\
\hline p29 & 26,743 & 16,533 & 10,210 & 3,950 & 0,065 & 6,47 \\
\hline p31 & 26,560 & 17,523 & 9,037 & 2,777 & 0,146 & 14,59 \\
\hline p32 & 29,573 & 16,633 & 12,940 & 6,680 & 0,010 & 0,98 \\
\hline p36 & 31,373 & 21,583 & 9,790 & 3,530 & 0,087 & 8,66 \\
\hline p37 & 28,730 & 19,130 & 9,600 & 3,340 & 0,099 & 9,88 \\
\hline $\mathrm{p} 42$ & 29,690 & 18,367 & 11,323 & 5,063 & 0,030 & 2,99 \\
\hline $\mathrm{p} 49$ & 29,413 & 20,057 & 9,357 & 3,097 & 0,117 & 11,69 \\
\hline Controle & 30,497 & 24,237 & 6,260 & 0,000 & 1,000 & 100,00 \\
\hline
\end{tabular}




\section{Discussão}

O reconhecimento e resposta imune para diferentes antígenos representam um processo de maturação que ocorre nos primeiros anos de vida. Neste período, são registradas as infecções de repetição mais comuns na clínica pediátrica, como otites, sinusites e pneumonias, as quais representam importante causa de morbidade, mortalidade e hospitalização em todo o mundo (Javier et al., 2000; Arruda et al., 1991). Porém, estas manifestações também representam as infecções de repetição mais comuns entre os pacientes com imunodeficiência primária (IDP). Para muitos imunodeficientes a realização de um diagnóstico precoce e o início da reposição com imunoglobulina humana podem prevenir significantemente a morbidade (Conley e Howard, 2002).

Pacientes com agamaglobulinemia ligada ao $X(X L A)$ são tipicamente acometidos por diversos eventos de infecções no trato respiratório durante os dois primeiros anos de vida. Por serem estas, infecções as queixas freqüentes, tanto nos consultórios pediátricos, como nos de alergia e Imunologia, o diagnóstico da XLA ocorre alguns anos após o início dos sintomas (Black et al., 2005).

Devido à baixa incidência de XLA, os primeiros trabalhos publicados sobre os aspectos clínicos e laboratoriais desta IDP eram realizados com pequenos números de pacientes. No Brasil, não se tem registro de estudos multicêntricos com portadores de imunodeficiências primárias, relatando os aspectos clínicos, aspectos laboratoriais e suas alterações genéticas. Com esta descrição dos achados moleculares em um grupo de pacientes brasileiros com XLA desenvolvemos um trabalho nacional pioneiro.

Nas últimas décadas, cinco trabalhos clínicos contando com um elevado número de pacientes foram publicados; nos EUA, o estudo contou com 96 pacientes (Lederman e Winkelstein, 1985); na Inglaterra, com 44 pacientes (Hermaszewski e Webster, 1993); na Itália foram estudados 73 pacientes (Plebani et al., 2002), o trabalho multicêntrico no Irã contou com um total de 33 pacientes (Moin et al., 2004) e na Espanha López-Granados (2005) foram descritos 54 pacientes. Foi em 2006 a última publicação sobre a clínica e os aspectos laboratoriais dos pacientes com XLA, com participação de 201 pacientes reportados desde 1999 nos EUA, originados de 66 centros de serviços ( Winkelstein e colaboradores). 
Nestes estudos a média da idade do diagnóstico dos pacientes com IDP foi de 5,3 anos. Pacientes onde a história familiar foi positiva, esta média foi significativamente inferior (2,59 anos). Winkelstein e colaboradores (2006) relataram que $34,5 \%$ dos pacientes com história familiar positiva tiveram o diagnóstico provável antes do inicio dos primeiros sintomas.

A casuística deste estudo se constitui de 33 pacientes provenientes de 29 famílias, acompanhados por dois serviços de alergia e imunologia da cidade de São Paulo, sendo 32 do sexo masculino e 1 do sexo feminino, com uma média de idade atual de 15 anos (intervalo de 4 anos a 35 anos). Observou-se que o início dos sintomas nos pacientes ocorreu, em $87 \%$ dos casos, até os dois anos de idade (média 11,83 $\pm 2,30$, limite 1 mês -4 anos), com o registro de 7 pacientes com início dos sintomas em idade inferior aos seis meses de idade, período onde ainda estariam protegidos pelos anticorpos maternos, transferidos passivamente pela placenta, durante o período gestacional. Ressaltamos que no grupo com início dos sintomas inferior a 6 meses de idade, 3 deles tem irmão com XLA. No estudo multicêntrico americano, observaram que em menos de $10 \%$ dos pacientes o início dos sintomas ocorreu em idade inferior a seis meses.

Um estudo sobre os polimorfismos de Tec demonstrou a contribuição destes polimorfismos na variabilidade clínica de XLA, onde nove polimorfismos apresentaram uma correlação significativa com a idade do diagnóstico e a percentagem de células $B$. Observou-se uma alta incidência do alelo $C$ do intron 1 em pacientes Afro-Americanos. Neste estudo não foi possível incluir a etnia como um fator de análise, devido as características de miscigenação étnica do povo brasileiro. Entretanto, destacamos três pares de irmãos com XLA, onde a etnia pode ser referenciada: pacientes $\mathrm{p} 4$ e $\mathrm{p} 7$ de descendência desdendência portuguesa, p5 ep6 de descencência libanesa e p15 e p16 de descendência italiana.

Nos EUA, 40\% das imunodeficiências primárias são diagnosticadas no primeiro ano de vida e outros $40 \%$ até a idade de cinco anos (Conley e Stehm, 1996), realidade esta que difere do nosso país, onde o percentual de IDP diagnosticadas até o primeiro ano de vida foi de $10 \%$. A chegada destes pacientes a um serviço de referência, de modo geral, é devida à ocorrência de uma infecção severa, que ocorre, em média, aos 5 anos de idade. A média da idade do

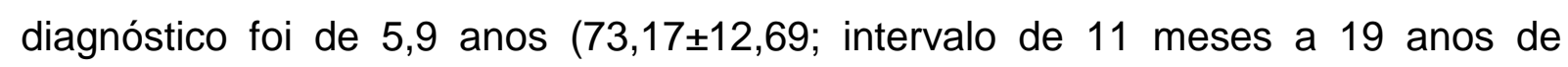
idade), representando um retardo no diagnóstico de 5 anos. Este diagnóstico tardio 
também é relatado por outros autores. O estudo realizado com pacientes Iranianos apresentou uma média do diagnóstico de 4,9 anos (intervalo 0,2-54 anos de idade); na Espanha, a média foi de 6,2 anos, embora o diagnóstico tenha sido estabelecido antes dos 3 anos de idade em $50 \%$ dos pacientes (intervalo 0,5-41 anos); na Itália, a média da idade do diagnóstico foi de 3,5 anos (intervalo 0,4-17 anos). Nos EUA, este quadro é diferenciado, onde a média de idade para o diagnóstico foi de 2,11 anos (limite 0,2-11 anos de idade) (Conley e Howard, 2002; Plebani et al., 2002; López-Granados et al., 2005; Rezael et al., 2006). Acredita-se que o atraso no diagnóstico destes pacientes possa contribuir para o baixo registro da incidência desta doença em nosso meio, levando muitas crianças a óbito antes da confirmação do diagnóstico.

Embora o diagnóstico em pacientes com XLA, de um modo geral, ocorra até os 5 anos de idade, a literatura revela casos de diagnóstico mais tardio. A maioria destes pacientes, de diagnostico mais tardio, ocorreu na idade adulta, durante uma avaliação devido a pneumonia recorrente, ou a sinusite persistente, ou ainda por diversas infecções do ouvido médio, sendo diagnosticados como XLA, através da análise mutacional de Btk. (Saffran et al, 1994; Hassimoto et al., 1999; Kanegane et al., 2001;Usui et al., 2001; Bulley, et al., 2002; Noordzij et al, 2002; Lin et al., 2006; Mitsui et al., 2006).

Stewart e colaboradores (2001) descreveram um paciente cuja avaliação laboratorial, aos 23 anos, mostrou uma hipogamaglobulinemia sugerindo diagnóstico de imunodeficiência comum variável. Análises realizadas neste paciente aos 40 anos de idade revelaram percentual de $1 \%$ de células $B$ em sangue periférico, e o estudo do gene da BTK detectou uma mutação em sítio de reconhecimento de splicing no intron 13.

Em outro estudo, a investigação de uma criança com 6 anos de idade com história de infecções de repetição revelou uma mutação no gene da BTK, que posteriormente também foi detectada em seu irmão assintomático, com 1 ano de idade, e em seu avô (paciente de 60 anos, anteriormente diagnosticado com imunodeficiência comum variável) (Morwood et al., 2004).

A história familiar é também parte fundamental para o diagnóstico de imunodeficiência primária. Uma criança com história de irmão falecido por infecção grave ou oportunista, ou de óbitos familiares inexplicáveis em idade precoce, é candidata à investigação de IDP. Além disso, a presença de consangüinidade 
aumenta a possibilidade de um paciente ter uma imunodeficiência primária de herança autossômica recessiva (Conley et al, 1999).

Em aproximadamente 50\% dos indivíduos com imunodeficiência ligada ao X não há história familiar prévia de imunodeficiência, pois a maioria destes pacientes constituem a $1^{\circ}$ manifestação de uma nova mutação (Buckley et al, 1997). A presença de consangüinidade parental aumenta a possibilidade de uma criança apresentar imunodeficiência primária autossômica recessiva.

Neste estudo a história familiar positiva não foi um fator determinante para o diagnóstico precoce de XLA. Entretanto, quando analisamos famílias com mais de um filho com XLA, observa-se uma precocidade no diagnóstico quando comparado com a idade do diagnóstico das demais famílias com história positiva, porém com um filho afetado. Também foi observado que em $40 \%$ dos nossos pacientes com histórias familiares positivas, dois relatos de consangüinidade na família (p5 e p6) e três casos de irmãos com XLA (p1 e p2; p4 e p7; p15 e p16). Os demais constam de relatos sobre parentes diretos (tios e avós) que tiveram infecções de repetição na infância ou faleceram com pouca idade por infecção ou diarréia sem diagnóstico definitivo. Nos diversos estudos de abordagem clinica demonstraram que uma história familiar positiva também não foi o fator que determinou uma precocidade no diagnóstico. Mesmo os pacientes com história positiva só foram diagnosticados após surgirem os primeiros sintomas (Broides et al., 2006).

A avaliação de um indivíduo com suspeita de imunodeficiência deve começar sempre com uma história clínica detalhada. É necessário abordar a freqüência, a duração, a gravidade e complicação das infecções ocorridas. O tipo de imunodeficiência a ser investigada é diferente conforme os sítios acometidos ou os germes mais freqüentes causadores de infecções nos pacientes (Bonilla e Geha, 2003). Infecções sinopulmonares de repetição por microrganismos extracelulares, especialmente os encapsulados como Streptococcus pneumoniae e Haemophilus influenza são comuns em pacientes com deficiência de células $B$, como agamaglobulinemia ligada ao $X$ (Yin et al, 2001). Estes pacientes têm susceptibilidade aumentada a meningoencefalites virais, principalmente por enterovirus (Plebani et al, 2002).

As infecções respiratórias e gastrointestinais foram as manifestações mais comuns relatadas neste estudo. A otite $(56,8 \%)$, a pneumonia $(51,4 \%)$ e a sinusite 
$(32,5 \%)$ foram as queixas mais comuns, seguido pela diarréia que acometeu $29,8 \%$ dos pacientes.

Estes quadros de infecções são os mais comuns apresentados nos diversos estudos de relatos clínicos de pacientes com XLA (Yin et al, 2001; Conley e Howard, 2002; Plebani et al., 2002; López-Granados et al., 20055; Kumar et al., 2006; Winkelstein et al., 2006).

O agente etiológico destas infecções raramente é isolado devido ao conhecimento prévio dos agentes patogênicos isolados nestes quadros, variando nas diferentes faixas etárias e também devido ao fato desta investigação não integrar a rotina do serviço de saúde, salvo em pacientes de UTI e casos de extrema gravidade. Os estudos realizados em outros países relatam como principal agente etiológico de pneumonia, o $S$. pneumoniae, seguido de $H$. influenza tipo b e Pseudomonas sp.; S. pneumoniae também é responsável pelos casos de meningites e sepse, sendo Pseudomonas spp. a bactéria mais associada com casos de sepse. As infecções cutâneas foram registradas como sendo causadas por Staphylococcus e Pseudomonas (Plebani et al., 2002; Kumar et al., 2006; Winkelstein et al., 2006).

Giardia lamblia é o protozoário mais comum associado aos casos de diarréia crônica e recorrente. $O$ espectro clínico das manifestações causadas por este agente pode ser desde assintomático até o estado de má absorção severa. É comum relato de casos de diarréia por este agente em pacientes com XLA (Subauste, 2006; Winkelstein et al., 2006).

O relato de infecções pós-vacinais é extremamente raro, porém Sarpong e colaboradores (2002) descreveram um paciente com 54 anos e diagnóstico definitivo de XLA que sobreviveu a uma infecção pelo vírus da vacina da pólio. No presente trabalho, o paciente p22 apresentou fezes positiva para o vírus da pólio, porém não houve desenvolvimento da infecção.

Nos pacientes com imunodeficiência humoral, a resposta imune mediada por células $\mathrm{T}$ se encontra inalterada, e em decorrência disto, estes pacientes raramente apresentam infecções por bactérias intracelulares como Salmonella sp. ou Serratia, por fungos ou Micobactérias (Plebani et al., 2002; Kumer et al., 2006).

Manifestações de auto-imunidade podem ser desencadeadas após episódios de infecção em pacientes com IDP. Os epítopos compartilhados entre antígenos próprios e estranhos confundem o sistema imune, que acaba reconhecendo tecidos e células próprias como se não o fossem. Já foram relatados casos de anemia 
hemolítica auto-imune em pacientes portadores de agamaglobulinemia ligada ao $\mathrm{X}$ (Petrovsky, 1996).

Nas últimas décadas, o avanço no conhecimento científico fez com que, a abordagem do sistema imune por meio de exames laboratoriais, crescesse em detalhamento e complexidade. Nos pacientes com agamaglobulinemia, os dados fornecidos pelos exames laboratoriais são suficientes para direcionar seu diagnóstico. Caso os pacientes sejam do sexo masculino podemos considerar ser uma agamaglobulinemia ligada ao $\mathrm{X}$, pois $85 \%$ dos casos de agamaglobulinemia são ligados ao X. Há uma tendência maior de acometimento do sexo masculino pelas imunodeficiências primárias, pois várias destas patologias têm herança genética ligada ao sexo (Conley e Stiehm, 1996).

O quadro laboratorial que sugere um diagnóstico de agamaglobulinemia se caracteriza por baixo percentual de células $B$ maduras em sangue periférico (menos de $2 \%$ ), baixas concentrações de todos os isotipos das imunoglobulinas e níveis normais nas dosagens das células CD3, CD4, CD8 e NK.

Embora os pacientes por nós estudados apresentem o quadro laboratorial acima descrito, observamos algumas variações em relação aos níveis das imunoglobulinas. Um paciente apresentou níveis elevados de IgM no diagnóstico ( $p 6=96,9 \mathrm{mg} / \mathrm{dl}$ ) e nas dosagens subseqüentes, os níveis desta imunoglobulina se manteve abaixo do percentil 3 da curva de normalidade (gráfico 8). Também observamos pacientes com valores de IgA acima do esperado em pacientes com agamaglobulinemia. Dentre estes pacientes, destacamos os pacientes p12 e p34 que apresentaram valores elevados desde o diagnóstico, e após o inicio da terapia com imunoglobulina humana estes níveis têm se mantido elevado. O paciente p12 mantêm os níveis acima do percentil 3 da curva de normalidade, entretanto o paciente p34 tem níveis considerados normais para a faixa etária. Nos outros três pacientes, os níveis altos de $\lg$ A se comportam de forma oscilatória, não se mantendo acima do percentil 3 da curva de normalidade (Gráfico 10). Nos pacientes, onde os níveis de IgA tem se mantido em valores superiores, observamos que a expressão da Btk se encontra em valores percentuais muito baixo (12\%) como no paciente $\mathrm{p} 12$.

Existe o relato de uma correlação entre os níveis de IgM com o padrão de mutação encontrado. Neste estudo os autores adotaram arbitrariamente a divisão de mutação leve e mutação severa, sendo esta última caracterizada por mutações de 
defeitos no sitio de splicing; stop codon prematuro e frameshift, os outros tipos de mutações foram classificados como forma leve da doença.

Estudos têm relatado pacientes com diagnóstico definitivo de XLA com níveis elevados de $\lg$, ou com níveis normais de $\lg A$ ou com níveis altos de $\operatorname{lgM}$, porém nenhum estudo relatou pacientes com XLA com níveis considerados elevados de dois ou mais isotipos ao mesmo tempo (Plebani et al., 2002; López-Granados et al., 2005; Broides et al., 2006; Winkelstein et al., 2006). Dado este observado em nossa casuística. Dentre os 6 pacientes que observamos alterações nas imunoglobulinas $A$ e $\mathrm{M}$, quatro deles foram identificados com mutação do tipo stop codon, no domínio quinase, em um deles ocorreu a troca de uma aminoácido no domínio $\mathrm{PH}$ e em outro paciente a mutação na Btk não foi observada pelos métodos por nós adotados neste trabalho. Entretanto a expressão da proteína, nestes pacientes, foi inferior a 13\%.

Os quadros clínicos e laboratoriais associados aos pacientes com agamaglobulinemia são os resultados de diversas alterações no gene btk responsável por codificar uma proteína que atua no desenvolvimento da linhagem das células $B$.

O gene btk é constituído por 19 éxons que codificam uma proteína de 659 aminoácidos distribuídos ao longo de 5 domínios [PH; TH (BTK+PRR); SH3; SH2 e SH1, também conhecido por Quinase], onde foram descritas mutações ao longo de todos os domínios. Este gene não traz hot spot para mutação, sendo todas elas distribuídas de forma uniforme ao longo de todos os domínios, proporcionalmente ao tamanho de cada um deles (Riikonen e Vihinen, 1999; Vihinen et al., 2000).

Esta proteína está intimamente envolvida nas vias de transdução de sinal, regulando a sobrevida, ativação, proliferação e diferenciação da linhagem de células B. BTK participa na via de transdução de sinal iniciado pela ligação de uma variedade de ligantes extracelulares em seus receptores de superfície (Hyvönen e Saraste, 1997; Vihinen et al., 2000; Mao et al., 2001).

Diversos estudos têm descrito mutações ao longo do gene BTK, porém em nenhum destes estudos se obteve sucesso ao correlacionar as manifestações clínicas e os dados laboratoriais com as mutações encontradas devido a grande diversidade desta doença (Jo et al., 2001; Speletas et al., 2001; Rodríguez et al., 2001; Danielian et al., 2003; Velickovic et al., 2004; Fiorini et al., 2004; Aghamohammadi et al., 2004; Kriusfek et al., 2006; Lopez-Herrera et al., 2007). 
A detecção de mutação na análise do gene da btk é realizado, em grandes centros de pesquisa nos países desenvolvidos através da técnica de SSCP que tem sensibilidade de $70 \%$ seguida de sequenciamento das alterações observadas, porém devemos considerar o alto risco de resultados falso positivo (Weston et al., 2001; Plebani et al., 2002; Granados et al., 2002; Broides et al., 2006; Chun et al., 2008). Adotamos como triagem de mutação esta técnica devido seu baixo custo e facilidade de execução, sendo utilizada para todos os pacientes na análise de todos os exons. Dos 33 pacientes deste estudo, 20 tiveram diagnóstico conclusivo para XLA; 3 pacientes o diagnóstico foi inconclusivo e em 10 pacientes não foi detectado a mutação pela técnica adotada, porém os níveis de expressão da proteína analisadas por real-time, foram inferiores a $20 \%$.

Dos pacientes com diagnóstico conclusivo, dez apresentaram mutações de troca de uma base (missense - 50\%); 5 constituíram de deleções ou inserções de uma base (nonssense - 25\%); três tiveram deleções de mais de uma bases (15\%) e dois $(10 \%)$ paciente apresentaram a deleção de uma base no sítio de reconhecimento de splicing. De acordo com Valiaho e colaboradores (2006) dos 973 pacientes descritos no banco de dados de Btk, com 620 mutações únicas, 40\% destas são do tipo missense com substituição de aminoácido e de stop codon prematuros, $17 \%$ são mutações nonssense, $20 \%$ deleções, $7 \%$ inserções e 16 mutações em sítios de splicing.

As mutações missense descritas neste estudo se concentraram nos domínios $\mathrm{PH}$ e Quinase da proteína e as demais mutações identificadas estão distribuídas nos domínios SH3 e SH2. O maior índice de mutações ocorreu no domínio Quinase representando $54 \%$ de todas as mutações descritas neste estudo. Isso é justificado quando observamos uma distribuição das mutações ao longo dos domínios das proteínas relativamente proporcional ao tamanho de cada domínio (Sigmon et al., 2008).

O domínio $\mathrm{PH}$ foi reconhecido recentemente, cuja função ainda é pouco esclarecida. Acredita-se que esteja envolvida na ancoragem da proteína `a superfície da membrana citoplasmática. Da família da tirosina quinase, a família TEC é a única que contém este domínio, sendo este seu diferencial para com as outras famílias da tirosina quinase. Mutações neste domínio estão concentradas em regiões de sítios de ligação causando distúrbios nas interações com os seus ligantes extracelulares. Mutações nas posições K12, N24, R28 e K53 interferem diretamente 
nos sítios de ligação do fosfato inositol, interferindo em sua estrutura. Dados estatísticos indicam que o codon R28 é hot spot para este domínio. Entretanto mutações nos sítios R13 e R133 são tolerantes a mutações. Demais mutações ao longo deste domínio irão alterar os sítios de ligação de ATP, causando sua inativação (Hyvönen e Saraste, 1997; Vihinen et al., 2000; Lindvall et al, 2005).

Neste estudo, descrevemos três mutações no domínio PH: S14P; K27N e $\mathrm{R} 28 \mathrm{H}$ (ocorridas nos pacientes p11; p12 e p22, respectivamente). A mutação no sítio R28 interferiu na estrutura protéica, alterando o sitio de ligação do lipidio fosfotidilinositol, sugerindo que esta alteração afete as vias de sinalização de células $B$ dependente de BTK, reduzindo a afinidade pelo fosfato inositol e consequentemente falhando na translocação da proteína a superfície celular. Acredita-se que o sitio K27 também participe da interação nesta ligação. (Monchese et al., 2000). A mutação de troca de um aminoácido no codon $S 14$, descrita neste trabalho, conduza a mudança estrutural deste domínio e consequentemente a inativação proteica (Futatani et al., 2001).

O paciente p11 apresentou seus primeiros sintomas com 1,9 ano de idade, sendo diagnosticado aos 3,2 anos de idade, tendo sido considerado com um quadro leve de infecções de repetição e ausência de complicações pós-terapia. Todos os isotipos das imunoglobulinas e percentual de células $B$ encontraram-se dentro dos critérios para XLA (Conley et al., 1999). O paciente p12 apresentou, além da mutação no domínio $\mathrm{PH}$, um polimorfismo no éxon 18 (c2033C>T) amplamente descrito. Estudo de expressão deste paciente demonstrou um decréscimo acentuado de $13 \%$ na expressão proteica. O início dos sintomas foi tardio quando comparado aos pacientes com mutações no mesmo domínio, como p11, porém com eventos de quadros infecciosos de maior incidência. $O$ diferencial deste paciente está na manutenção de níveis elevados da imunoglobulina A. Para os demais isotipos, os níveis se mantiveram inferiores e o percentual de células $B$ foi compatível com o diagnóstico de XLA.

O paciente p22 apresentou maior gravidade em sua clínica, ocorrendo óbito antes da finalização deste estudo e antes do diagnóstico definitivo para XLA. O início do primeiro sintoma ocorreu ao primeiro mês de vida, sendo diagnosticado aos 3,10 anos de idade. Apresentou insuficiência respiratória aos 10 meses de idade, diagnosticado como causa bronquiectasia, além da positividade para poliovírus nas fezes. Aos oito anos de idade, apresentou hipocalcemia sintomática. 
A mutação $\mathrm{R} 28 \mathrm{H}$ é regularmente descrita neste domínio, no entanto as mutações S14P e K27N foram detectadas pela primeira vez no presente trabalho. O quadro clínico acima descrito nos leva a considerar a diversidade das manifestações encontradas entre pacientes acometidos por mutações no mesmo domínio.

O paciente p42, que apresentou uma alteração no intron 4 na região de splicing, teve bom desenvolvimento clínico, não tendo registro de intercorrências grave. Os níveis de expressão da Btk neste paciente foram extremamente baixos (3\%), e os níveis das imunoglobulinas e de células B estão dentro do parâmetro para XLA.

O domínio SH3 é requerido na regulação da atividade da enzima. BTK é ativada por fosforilação, e sua atividade se completa após a ativação do domínio quinase que ocorre na fosforilação do resíduo da tirosina Y551 e conseqüentemente a autofosforilação do resíduo Y223 no domínio SH3. Este domínio pode alterar a estrutura da proteína causando distúrbios na interação com uma ou mais proteínas ligantes a este domínio, e causando a interrupção do processo de transdução de sinal na diferenciação de células B (Vihinen et al., 2000; Mesci et al., 2006).

Mutações neste domínio foram encontradas em um casal de irmãos (p4 e p7), os quais carregam a mutação de troca de uma base $(g 61392 \mathrm{G}>\mathrm{A})$ no sítio de reconhecimento de splicing, ocasionando alterações estruturais, gerando uma proteína truncada ou pouco funcional. Entretanto ao analisarmos as expressões da Btk nestes pacientes observamos níveis de expressão superior a média do grupo de estudo (27\% e $31 \%$ ) sugerindo que a mutação destes pacientes, gerou uma proteína com baixa atividade protéica (Väliaho et al., 2006).

Apesar de albergarem a mesma mutação, o quadro clínico entre eles se diferencia quanto ao número de eventos de infecções e gravidade das mesmas, onde o paciente $\mathrm{p} 7$ foi acometido por maiores eventos de infecções de repetição se comparado ao seu irmão (p4). Considerando que ambos tiveram as mesmas condições sócio-econômicas, culturais e hábitos de vida, esperava-se comportamento semelhante quanto as suas manifestações, como também se esperava um diagnóstico precoce no irmão mais novo (p4) em decorrência do diagnóstico de IDP no irmão mais velho (p7), porém observamos que o diagnóstico só foi realizado alguns anos após o surgimento dos primeiros sintomas, em ambos os irmãos. 
Neste mesmo domínio, relatamos a deleção de uma base (g61328delG) no paciente 18, gerando um stop codon prematuro na posição I276 (I276X) sintetizando uma proteína não funcional que geralmente é degrada após sua síntese. O paciente apresentou um quadro característico para o diagnóstico de XLA quanto às manifestações clínicas e laboratoriais. Entretanto o estudo deste paciente se limitou a localização da mutação devido ao desligamento do paciente do programa de atendimento. Até o presente estudo, não foram descritos mutações missense para este domínio (Vihinen et al., 2001).

O domínio SH2 participa de interações intramoleculares para a regulação da atividade quinase via fosforilação do resíduo da tirosina, possibilitando a interação deste domínio com outras moléculas, ativando as vias de fluxo de cálcio e o receptor de fator nuclear (LaFevre-Bernt et al., 1998; Briggs e Smith et al., 1999). O paciente p30 apresentou deleção de um nucleotídeo na posição g63041, alterando um aminoácido no exon 11.

Alterações neste domínio não afetam a atividade quinase da proteína, porém interferem crucialmente na habilidade de Btk induzir o fluxo de cálcio sobre o estímulo de BCR (Guo et al., 2005).

O domínio quinase da proteína BTK compreende o maior domínio em número de mutações descritas, tendo as mutações missense colaborado com grande parte destas mutações. Este domínio compreende aproximadamente 250 resíduos de aminoácidos e sua estrutura tridimensional revela uma divisão em dois subdomínios, um superior e outro inferior. O centro da função catalítica reside nos sítios de ligação do substrato e de ATP, que consistem em resíduos altamente conservados (Xu et al., 1997; Mao et al., 2001).

Mutações missense neste domínio têm demonstrado que a total ausência de expressão da proteína nem sempre é observada, presumindo-se que a expressão da proteína é silenciosamente preservada, porém os níveis reduzidos de expressão sugerem uma instabilidade na proteína mutada (Parolin et al., 1994; Xu et al., 1997; Gaspar et al., 2000; Vihinen et al., 2000).

Diversos autores têm atribuído às manifestações mais leves de XLA a mutação missense neste domínio (Gaspar et al., 2000; Plebani et al., 2002; LópezGranados et al., 2005; Broides et al., 2006; Winkelstein et al., 2006). Neste estudo, detectamos no domínio quinase, quatro mutações de troca de uma base (missense); 
deleção de uma base e deleção de 4 bases em sítio de reconhecimento de splicing, a deleção de duas bases e duas inserções de uma base (nonssense).

Os pacientes p23, p26, p28 e p31 apresentaram as mutações missense (S592, R525 e R562) sendo que dois deles, p28 e p31 apresentaram a mesma mutação, porém são de famílias distintas. O paciente p28 apresentou o quadro mais leve da XLA em relação as infecções relatadas, quando comparado ao paciente p31 que apresentou quadro clínico característico para XLA, com diversos eventos de infecções de repetição do trato respiratório. O paciente p23 demonstrou maior severidade em seu quadro clínico, apresentando bronquiectasia, lobectomia do lado esquerdo atelectasias e diarréia crônica, além das infecções características para XLA (otite, sinusite e pneumonia).

O paciente p9 apresentou quadros extras de artrite séptica, diarréia crônica e febre intermitente (8 meses). Uma mutação no domínio quinase de deleção de 4 bases no íntron 15 (g66769delTTTG) originando uma proteína não funcional, onde o éxon 16 se encontra ausente no mRNA (Danielian et al., 2003). Observamos neste paciente que os níveis de IgA mantiveram-se normais para a faixa etária, mas nas demais imunoglobulinas se mantiveram abaixo da faixa de normalidade para a faixa etária.

Nos pacientes p15 e p16 (irmãos), a deleção de duas bases (g68190delGA) no exon 18, gerou um stop codon prematuro na posição E598 (E598X). Nestes pacientes, além da mutação acima, apresentaram um polimorfismo na posição g68273C > T, também observado no paciente p12. Estes irmãos apresentaram níveis de expressão da proteína extremamente baixos, não superando os $7 \%$ de expressão.

A precocidade no diagnóstico destes irmãos (11 meses) é um diferencial em relação aos demais pacientes aqui descritos. Semelhante ao paciente p9, também observamos no paciente p15 a manutenção de níveis de $\lg A$ considerados normais para a faixa etária, a qual foi ausente em seu irmão. O paciente p16 apresentou maiores eventos de infecções de repetição em relação ao seu irmão, que apresentou quadros de infecções mais graves.

Interessantemente, outro casal de irmãos (p5 e p6) demonstrou o mesmo perfil de expressão protéica que o casal de irmãos anteriormente descrito, com expressão inferior a $3 \%$. No entanto, a mutação descrita para este casal foi na posição g68159 onde ocorreu a inserção de uma base (g68159insA) originando um 
stop codon prematuro. O p6 também manteve níveis de IgA considerados normais para a faixa etária e apresentou uma forma mais branda da doença, enquanto seu irmão (p4) teve baixo número de infecções, porém com quadros de maior gravidade. Estes dois casais de irmãos apresentam história de consangüinidade.

Os pacientes $\mathrm{p} 1$ e $\mathrm{p} 2$ com diagnóstico provável para XLA, não foram localizado mutação através das técnicas utilizadas neste estudo, entretanto o estudo de expressão para o gene demonstrou uma redução drástica nos níveis da proteína. No paciente p34 com $8,4 \%$ de células B (Anexo IV), os níveis das imunoglobulinas se encontravam sugestivo para o diagnóstico de XLA. A análise de expressão deste paciente apresentou valores inferiores a $10 \%$ de expressão, porém não foi identificado mutações nos exons estudados. Neste caso, outras técnicas de detecção de mutação deverão ser aplicadas.

Dos pacientes deste estudo, onde a mutação não foi descrita, um deles, o paciente p20 foi considerado não XLA, além da ausência da mutação, os níveis de expressão de BTK foram altos (60\%), entretanto devemos considerar o fato de que a literatura traz diversos casos de pacientes com diagnóstico sugestivo para XLA, com ausência de mutação e níveis normais de expressão protéica, porem com diagnóstico negativo para outras IDPs (Plebani et al., 2002; López-Granados et al., 2005; Broides et al., 2006). O diagnóstico para XLA será negativo se confirmado diagnóstico de outra IDP. Seis pacientes apresentaram níveis baixos de expressão da proteína e em 7 o diagnóstico para Btk foi inconclusivo.

A literatura descreve que aproximadamente $15 \%$ dos pacientes com fenótipo de XLA têm agamaglobulinemia autossômica recessiva. Destes, 20 a 30\% tem mutações no loci que codificam a região constante $\mu$ da cadeia pesada (LópezGranados et al., 2005). Outros fatores que são essenciais para o processo de maturação da linhagem de células $B$ também podem ser afetados (Conley et al., 2005). Os pacientes que obtiverem o diagnóstico inconclusivo para XLA, serão investigados quanto a alterações nos outros fatores envolvidos no processo de desenvolvimento das células $\mathrm{B}$.

Os quadros clínicos, achados laboratoriais e as mutações descritas até aqui nos revelam uma rede de informações que aparentemente não são conclusivas se tentarmos correlacioná-las. Alguns pesquisadores investigaram uma possível ligação entre as manifestações clínicas dos pacientes, com seus níveis de imunoglobulinas e as alterações na estrutura do gene encontradas. Alguns estudos relataram uma 
provável relação entre os níveis de $\operatorname{lgM}$ com o tipo de mutação, outros não observaram correlação entre níveis de $\operatorname{lgM}$ nos pacientes e as mutações encontradas (Plebani et al, 2002; Broides et al., 2006). Outro grupo correlacionou o tipo de mutação, classificada como leve (missense) e severa (stop códon, splicing site recognition) com os dados clínicos e laboratoriais (López-Granados et al, 2005).

Os pacientes do nosso estudo apresentaram o perfil molecular e das infecções de repetição, condizentes com o que é descrito atualmente na literatura. Considerando a miscigenação do povo brasileiro, as condições sócio-ecômicas e culturais do nosso país, o padrão de apresentação da doença, tipos de infecções e agentes etiológicos e a idade do diagnóstico da IDP observamos semelhança aos trabalhos multicêntricos desenvolvidos em países como EUA, Espanha, Itália e Iran (Plebani et al., 2002; Moin et al., 2004; López-Granados et al., 2005; Broides et al., 2006; Winkelstein et al., 2006).

Esta heterogeneidade clínica não reflete as consequências das diferentes mutações encontradas para este gene. As mutações em Btk são altamente variadas e suas consequências clínicas não se correlacionam, indicando que outros fatores contribuem para o fenótipo e a severidade desta doença. Fatores ambientais e as modificações gênicas têm influencia no padrão de expressão da deficiência de células $\mathrm{B}$. 


\section{Conclusão}

Há uma inviabilidade de estabelecer uma correlação entre o fenótipo de XLA e seu genótipo devido à diversidade das manifestações como das localizações e tipos de mutações.

Irmãos com XLA possuem a mesma mutação, porém suas manifestações são distintas.

A diversidade de mutação ao longo do gene da btk, incluindo regiões promotoras, inviabiliza, em curto prazo, o desenvolvimento de uma terapia gênica.

Compreender os motivos, além dos fatores genéticos, que levam esta doença a se manifestar de forma tão heterogênea é o grande desafio.

Estudos sócio-ambientais e sócio-culturais em famílias com IDP pode ser um caminho para acharmos a razão desta diversidade. 


\section{Referências Bibliográficas}

Aghamohammadi A, Parvaneh N, Kanegana H, Moin M, Amirzargar AA, Farhoudi A, et al. Screening of the Bruton tyrosine kinase (BTK) gene mutations in 13 Iranian patients with presumed X-linked agammaglobulinemia. Iran $\mathrm{J}$ Allergy Asthma Immunol. 2004;3:175-179.

Akashi K, Kondo M, Cheshier S, Shizuru J, Gandy K, Domen J, et al. Lymphoid development from stem cells and the common lymphocyte progenitors. Cold Spring Harb Symp Quant Biol. 1999;64:1-12.

Allman D, Li J, Hardy RR. Commitment to the B lymphoid lineage occurs before DHJH recombination. J Exp Med. 1999;189(4):735-740.

Arai A, Kitano A, Sawabe E, Kanegane H, Miyawaki T, Miura O. Relapsing Campylobacter coli bacteremia with reactive arthritis in a patient with $\mathrm{X}$-linked agammaglobulinemia. Intern Med. 2007;46(9):605-609.

Arruda LK, Rizzo MC, Chapman MD, Fernandez-Caldas E, Baggio D, Platts-Mills TA, et al. Exposure and sensitization to dust mite allergens among asthmatic children in São Paulo, Brazil. Clin Exp Allergy. 1991;21(4):433-439.

Bajpai UD, Zhang K, Teutsch M, Sen R, Wortis HH. Bruton's tyrosine kinase links the B cell receptor to nuclear factor kappaB activation. J Exp Med. 2000;191:1735-1744.

Black C, Zavod MB, Gosselin BJ. Haemophilus influenza lymphadenopathy in a patient with agammaglobulinemia. Arch Pathol Lab Med. 2005;129:100-103.

*De acordo com:

International Committee of Medical Journal Editors. Uniform requirements for manuscripts submitted to Biomedical Journal: sample references. c2003 - [updated 2005 June 15; cited 2006 May 16]. Available from: http://www.nlm.nih.gov/bsd/uniform_requirements.html. 
Broides A, Yang W, Conley ME. Genotype/phenotype correlations in x-linked agammaglobulinemia. Clin Immunol. 2006;118:195-200.

Bruton, O. Agamaglobulinemia, Pediatrics. 1952;9:722-727.

Buckley RH, Schiff RI, Schiff SE, Markert ML, Williams LW, Harville TO, et al. Human severe combined immunodeficiency: genetic, phenotypic, and functional diversity in one hundred eight infants. J Pediatr. 1997;130(3):378-387.

Carneiro-Sampaio, MMS. Primary Immunodeficiencies in Latin America. Allergy Clin Immunol Int. 1999;11(5):157-161.

Chomczynski, P; Sacchi, N. Single-step method of RNA isolation by acid guanidinium thiocyanate-phenol-chloroform extraction. Anal Biochem. 1987;162 (1):156-159.

Conley ME, Broides A, Hernandez-Trujillo V, Howard V, Kanegane H, Miyawaki T, et al. Genetic analysis of patients with defects in early B-cell development. Immunol Rev. 2005;203:216-234.

Conley ME, Howard V. Clinical findings leading to the diagnosis of X-linked agammaglobulinemia. J Pediatr. 2002;141:566-571.

Conley ME. Diagnostic guidelines--An International Consensus document. Clin Immunol. 1999;93(3):189.

Conley ME e Stiehm ER. Immunodeficiency Disorders: General Considerations. In: Stiehm, ER. Immunologic Disordes in infants and children. Philadelphia, WB Saunders, 1996, $4^{\text {th }}$ ed., p. 201-249.

Cunningham-Rundles C, Ponda P P. Molecular defects in T- and B-cell primary immunodeficiency diseases. Nat Rev Immunol. 2005;5(11):880-892.

Danielian S, El-Hakeh J, Basilico G, Oleastro M, Rosenzweig S, Feldman G, et al. Bruton's Tyrosine Kinase gene mutations in Argentina. Hum Mutat. 2003;21:451. 
De Weers M, Verschuren MC, Kraak-man ME. Mensink RG, Schuurman PK, et al. The Bruton's tyrosine kinase gene is expressed throughout $B$ cell differentiation, from early precursos $B$ cell stages preceding immunoglobulin gene rearrangement up to mature B cell stages. Eur J Immunol. 1993;23:3109-3114.

Dunnen JTd, Antonarakis E. Nomenclature for the description of human sequence variations. Human Genetic. 2001;109:121-124.

Ferrari S, Lougaris V, Caraffi S, Zuntini R, Yang J, Soresina A, et AL. Mutations of the IgB gene cause agammaglobulinemia in man. J Exp Med. 2007;204:2047-2051.

Fiorini M, Franceschini R, Soresina A, Schumacher R-F, Ugazio AG, Rossi P, et al. BTK: 22 novel and 25 recurrent mutations in European patients with $X$-linked agammaglobulinemia. Hum Mutat. 2004;23:286.

Fluckiger AC, Li Z, Kato RM, Wahl MI, Ochs HD, et al. Btk/Tec kinases regulate sustained increases in intracellular $\mathrm{Ca} 2+$ following $\mathrm{B}$-cell receptor activation. EMBO J. 1998;17:1973-1985.

Gaspar, HB \& Kinnon, C. (2001) X-Linked Agamaglobulinemia. Immunol Allergy Clin North Am. 2001;21(1):23-43.

Gauld SB, Dal Porto JM, Cambier JC. B cell antigen receptor signaling: roles in cell development and disease. Science. 2002;296:1641-1642.

Geha RS, Notarangelo LD, Casanova JL, Chapel H, Conley ME, Fischer A, et al. Primary immunodeficiency diseases: an update from the International Union of Immunological Societies Primary Immunodeficiency Diseases Classification Committee. J Allergy Clin Immunol. 2007;120(4): 776-794.

Go NF, Castle BE, Barrett R, Kastelein R, Dang W, et al. Interleukin 10, a novel B cell stimulatory factor: unresponsiveness of $X$ chromosome-linked immunodeficiency B cells. I Exp Med. 1990;172:1625-1631. 
Granados EL, Porpiglia AS, Hogan MB, Matamoros N, Krasovec S, Pignata C, et al. Clinical and Molecular Analysis of patients with defects in $\mu$ heavy chain gene. $\mathrm{J}$ Clin Invest. 2002;110(7)1029-1035.

Grunebaum MD. Agammaglobulinemia caused by defects other than btk. Immunol Allergy Clin North Am. 2001;21(1)45-63.

Guo S, Wahl MI, Witte ON. Mutational analysis of the SH2-kinase linker region of Bruton's tyrosine kinase defines alternative modes of regulation for cytoplasmic tyrosine kinase families. Int Immunol. 2005;18:79-87.

Hagemann TL, Yuexin C, Rosen FS, Kwan SP. Genomic organization of the Btk gene and exon scanning for mutations in patients with X-linked Agamaglobulinemia. Human Mol Genet. 1994;3(10):1743-1749.

Hardy RR, Hayakawa K. (1991) A developmental switch in B lymphopoiesis. Proc Natl Acad Sci USA.;88(24):11550-11554.

Hardy RR, Hayakawa K.) B cell development pathways. Annu Rev Immunol. 2001;19:595-621.

Hashimoto S, Tsukada S, Matsushita M, Miyawaki T, Niida Y, Yachie A, et al. Identification of Bruton's tyrosine kinase (Btk) gene mutations and characterization of the derived proteins in $35 \mathrm{X}$-linked agammaglobulinemia families: a nationwide study of Btk deficiency in Japan. Blood. 1996;88:561-573.

Hendriks RW, de Bruijn MF, Maas A, Dingjsn GM, Karis A, Grosveld F. Inactivation of Btk by insertion of lacZ reveals defects in $B$ cell development only past the pre-B cell stage. EMBO J. 1996;15:4862-4872.

Hermaszewski RA, Webster AD. Primary hypogammaglobulinaemia: a survey of clinical manifestations and complications. Q J Med. 1993;86(1):31-42. 
Hyvonen M, Saraste M. Structure of the PH domain and Btk motif from Bruton's Tyrosine Kinase: molecular explanations for x-linked agammaglobulinemia. EMBO J. 1997;16:3396-3304.

Horwood NJ, Mahon T, Campbell J, Mano H, Bremann FM, Webster D, et al. Bruton's tyrosine kinase is required for lipopolysaccharide-induced tumor necrosis factor alpha production. J Exp Med. 2003;197:1603-1611.

Jacobsen K, Kravitz J, Kincade P W, Osmond D G.) Adhesion receptors on bone marrow stromal cells: in vivo expression of vascular cell adhesion molecule-1 by reticular cells and sinusoidal endothelium in normal and gamma-irradiated mice. Blood. 1996;87(1):73-82.

Javier FC 3rd, Moore CM, Sorensen RU. Distribution of primary immunodeficiency diseases diagnosed in a pediatric tertiary hospital. Ann Allergy Asthma Immunol. 2000;84(1):25-30.

Jefferies CA, Doyle S, Brunner C, Dunne A, Brint E, et al. Bruton's tyrosine kinase is a Toll/interleukin-1 receptor domain-binding protein that participates in nuclear factor KB activation by Toll-like receptor 4. I Biol Chem. 2003; 278:26258-26264.

Jo EK, Kanegane H, Nonoyama S, Tsukada S, Lee JH, Lim K, et al. Characterization of mutations, including a novel regulatory defect in the first intron, in Bruton's tyrosine kinase gene from seven Korean X-linked agammaglobulinemia families. J Immunol. 2001;167(7):4038-4045.

Jumaa H, Hendriks RW, Reth M. B cell signaling and tumorigenesis. Annu Rev Immunol. 2005;23:415-445.

Kanegane H, Futatani T, Wang $\mathrm{Y}$, Nomura K, Shinozaki K, Matsukura $\mathrm{H}$, et al. Clinical and mutational characteristics of $\mathrm{X}$-linked agammaglobulinemia and its carrier identified by flow cytometric assessment combined with genetic analysis. J Allergy Clin Immunol. 2001;108:1012-1020. 
Kawakami Y, Yao L, Miura T, Tsukada S, Witte ON, Kawakami T. Tyrosine phosphorylation and activation of Bruton tyrosine kinase upon FcERI, cross-linking. Mol Cell Biol. 1994;14:5108-5113.

Kelly, ME; Chan, AC. Regulation of B cell function by linker proteins. Curr Opin Immunol. 2000;12(3):267-275.

Kersseboom R, Ta VBT, Zijlstra E, Middendorp S, Jumaa H, van Lobo PF, et AL. Bruton's Tyrosine Kinase and SLP-65 regulate pré-B cell differentiation and the induction of Ig light chain gene rearrangement. J Immunol. 2006;176:4543-4552.

Kumar A, Teuber SS, Gershwin ME. Current perspectives on primary immunodeficiency diseases. Clin Dev Immunol. 2006;13:223-259.

Lederman HM, Winkelstein JA. X-linked agammaglobulinemia: an analysis of 96 patients. Medicine. 1985; 64(3):145-56.

Leiva LE, Zelazco M, Oleastro M, Carneiro-Sampaio M, Condino-Neto A, CostaCarvalho BT, et al. Primary immunodeficiency diseases in Latin America: the second report of the LAGID registry. J Clin Immunol. 2007;27(1):101-108.

Lindvall JM, Blomberg KEM, Väliaho J, Vargas L, Heinonen JE, Berglöf A, et al. Bruton's tyrosine kinase: cell biology, sequence conservation, mutation spectrum, siRNA modifications and expression profiling. Immunol Rev. 2005;203:200-215.

Liu W, Saint DA. A new quantitative method of real time reverse transcription polymerase chain reaction assay based on simulation of polymerase chain reaction kinetics. Anal Biochem. 2002; 302:52-59.

Löffert D, Ehlich A, Müller W, Rajewsky K. Surrogate light chain expression is required to establish immunoglobulin heavy chain allelic exclusion during early $B$ cell development. Immunity. 1996;4(2):133-144. 
Lopez-Granados E, Diego RPd, Cerdán AF, Casariego GF, Rodriguez MCG. A genotype-phenotype correlation study in a group of 54 patients with X-linked agammaglobulinemia. J Allergy Clin Immunol. 2005;116:690-697.

Mao C, Zhou M, Uckun FM. Crystal structure of Bruton's tyrosine kinase domain suggests a novel pathway for activation and provides insights into the molecular basis of X-linked agammaglobulinemia. J Biol Chem. 2001;44:41435-41443.

Martinez G, Shaw EM, Carrillo M and Zanuy S. Protein Salting-Out Method Applied to Genomic DNA Isolation from Fish Whole Blood. Biotechniques 1998;24:238-239.

Meffre E, Casellas R, Nussenzweig MC. Antibody regulation of B cell development. Nat Immunol. 2000;1(5):379-85.

Mesci L, Özdag H, Turul T, Ersoy F, Tezcan I, Sanal Ö A novel mutation leading to a deletion in the SH3 domain of Bruton's tyrosine kinase. Turk J Pediatri. 2006;48:362364.

Milili M, Antunes H, BBlanco-Betancourt C, Nogueiras A, Santos E, Vasconcelos J, Melo JC, Schiff $C$ (2002) A new case of autosomal recessive agammaglobulinaemia with impaired pre-B cel differentiation due to a large deletion of the IGH locus. European Journal Pediatria 161: 479-484.

Miller SA, Dykes DD and Polesky HF. (1988) A Simple Salting Out Procedure for Extracting DNA from human nucleated cells. Nucleic Acids Research 16: 1215.

Minegishi Y, Coustan-Smith E, Wang Y-H, Cooper MD, Campana D, Conley ME. Mutations in the human $\lambda 5 / 14.1$ gene result in $B$ cell deficiency and agammaglobulinemia. J Exp Med. 1999a;187:71-77.

Minegishi Y, Coustan-Smith E, Rapalus L, Ersoy F. Campana D. Conley ME. Mutations in Iga (CD79a) result in a complete block in B cell dvelopment. J Clin Invest. 1999b;104:1115-1121. 
Minegishi Y, Rohrer J, Coustan-Smith E, Lederman HM, Pappu R, Campana D, et al. An essential role for BLNK in human B cell development. Science 1999c. 286:19541957.

Mohamed AJ, Nore BF, Christensson B, Smith CL. Signalling of Bruton's Tyrosine Kinase, BTK. Scand J Immunol. 1999;49:113-118.

Moin M, Aghamohammadi A, Farhoudi A, Pourpak Z, Rezaei N, Movahedi M, et al. $X$-linked agammaglobulinemia: a survey of 33 Iranian patients. Immunol Invest. 2004;33(1):81-93.

Morwood K, Bourne H, Gold M, Gillis D, Benson EM Phenotypic variability: clinical presentation between the 6th year and the 60th year in family with $x$-linked agammaglobulinemia. J Allergy Clin Immunol. 2004;113:783-785

1: Nat Rev Immunol. 2006 Apr;6(4):283-94.

Monroe J. ITAM-mediated tonic signaling through pre-BCR and complexes. Nat Rev Immunol. 2006;6(4):283-294.

Noguera NI, Tallano CE, Bragós IM, Milani AC. Modified Salting-out method for DNA isolation from newborn cord blood nucleated cells. J Clinl Lab Anal. 2000;14:280283.

Nore BF, Vargas L, Mohamed AJ, Bradén LJ, Bäckesjö CM, Islam TC. Redistribution of Bruton's tyrosine kinase by activation of phosphatidylinositol 3-kinase and Rhofamily GTPases. Eur J Immunol. 2000;30:145-154.

Orita, M; Iwahana, H; Kanazawa, H; Hayashi, K; Sekiya, T. Detection of polymorphisms of human DNA by gel electrophoresis as single-strand conformation polymorphisms. Proc Natl Acad Sci U S A. 1989;8:2766-2770.

Parolin C, Dorfman T, Palú G, Göttlinger H, Sodroski J. (1994); Analysis in human immunodeficiency virus type 1 vectors of cis-acting sequences that affect gene transfer into human lymphocytes. J Virol.; 68(6): 3888-3895. 
Petrovsky N. (1996); The paradoxical association between immunodeficiency and autoimmunity: comment on the article by Atkinson. Arthritis Rheum.; 39(1): 179-180.

Pfaffl MW. A new mathematical model for relative quantification in real-time RT-PCR. Nucleic Acids Res. 2001; 29:45.

Plebani A, Soresina A, Rondelli R, Amato GM, Azzari C, Cardinali F, Cazzola G, al e (2002) Clinical, imunological, and molecular analysis in a large cohort of patients with x-linked agammaglobulinemia: an Italian multicenter study. Clinical Immunology 104: 221-230.

Primary Immunodeficiency diseases. Report of na IUIS Scientific Group. Clin Exp Immunol. 1999;118(Suppl 1):1-28.

Przylepa J, Himes C, Kelsoe G. (1998) Lymphocyte development and selection in germinal centers. Curr Top Microbiol Immunol.; 229: 85-104.

Queck LS, Bolen J, Watson SP. A role for Bruton's tyrosine kinase (Btk) in platelet activation by collagen. Curr Biol. 1998;8:1137-1140.

Rawlings DJ, Scharenberg AM, Park H, Wahl MI, Lin S, et al. Activation of BTK by a phosphorylation mechanism initiated by SRC family kinases. Science. 1996;271:82225.

Reth, M; Wienands, J. (1997) Iniciation and processing of signals from the B cell antigen receptor. Annual Reviews in Immunology, 15: 453-479.

Rezael N, Aghamohammadi A, Moin M, Pourpak Z, Movahedi M, Gharagozlou M, et al. Frequency and clinical manifestations of patients with primary immunodeficiency disords in Iran: Update from the Iranian primary imunodeficiency registry. J Clin Immunol. 2006;26:519-532.

Riikonen P, Vihinen M. MUTbase: maintenance and analysis of distributed mutation databases. Bioinformatics. 1999;15(10):852-859. 
Rodriguez MCG, Lopez-Granados E, Cerdán AF, Casariego GF. Molecular analysis of Bruton's Tyrosine Kinase gene in Spain. Hum Mutat. 2001;18:84.

Rolink A, Nutt S, Busslinger M, ten Boekel E, Seidl T, Andersson J. Differentiation, dedifferentiation, and redifferentiation of B-lineage lymphocytes: roles of the surrogate light chain and the Pax5 gene. Cold Spring Harb Symp Quant Biol. 1999;64:21-25.

Rosen FS, Cooper MD, Wedgwood JP. The primary immunodeficiencies. N Engl J Med. 1995;333:431-440.

Salim K, Bottomley MJ, Querfurth E, Zvelebil MJ, Gout I, Scaife R, et al. Distinct specificity in the recognition of phosphoinositides by the pleckstrin homology domains of dynamin and Bruton's tyrosine kinase. EMBO J. 1996;15(22):6241-6250.

Sarpong S, Skolnick HS, Ochs HD, Futatani T, Winkelstein JA Survival of wild polio y a patient with XLA. Ann Allergy Asthma Immunol. 2002;88:59-60.

Sato S, Katagiri T, Takaki S, Kikuchi Y, Hitoshi Y, et al. IL-5 receptor-mediated tyrosine kinase phosphorylation of $\mathrm{SH} 2 / \mathrm{SH} 3$-containing proteins and activation of Bruton's tyrosine and Janus 2 kinases. J Exp Med. 1994;180:2101-2111.

Scharemberg AM, El-Hilal O,Fruman DA, Beitz LO,Li Z, Lin S, et al. Phosphatidylinositol-3,4,5-trisphosphate (Ptdlns-3,4,5-P3)/Tec kinase-dependent calcium signaling pathway: a target for SHIP-mediated inhibitory signals. EMBO J. 1998;17:1961-1972.

Schebesta M, Pfeffer PL, Busslinger M. Control of pre-BCR signaling by Pax5dependent activation of the BLNK gene. Immunity. 2002;17(4):473-485.

Schmidt NW, Thieu VT, Mann BA, Ahyi ANN, Kaplan MH. Bruton's Tyrosine Kinase is required for TLR-induced IL-10 production. J Immunol. 2006;177:7203-7210. 
Schmidit U, Van Den Akker E, Parren-Van Amelsvoort M, Litos G, De Bruijn M, et al. Btk is required for an efficient response to erythropoietin and for SCF-controlled protection against TRAIL in erythroid progenitors. I Exp Med. 2004;199:785-795.

Shen $\mathrm{B}$, Vihinen $\mathrm{M}$. Conservation and covariance in $\mathrm{PH}$ domain sequences: physicochemical profile and information theoretical analysis of XLA-causing mutations in the Btk PH domain. Protein Eng Des Sel. 2004;17(3):267-276.

Smith CL, Islam TC, Mattsson PT, Mohamed AJ, Nore BF, Vihinen M. Tec family of cytoplasmic tyrosine kinases: mammalian Btk, Bmx, Itk, Tec, Txk and homologs in other species. Bioessays. 2001;23:436-446.

Speletas M, Kanariou M, Kanakoudi-Tsakalidou F, Papadopoulou-Alataki E, Arvanitidis K, Pardali E, Constantopoulos A, al e (2001) Analysis of BTK mutations in patient with $x$-linked agammaglobulinemia (XLA) and determination of carrier status in normal female relatives: a nationwide study of BTK deficiency in Greece. Scandinavian Journal of Immunology 54: 321-327.

Stewart DM, Tian L, Nelson DL (2001) A case of x-linked agammaglobulinemia diagnose in adulthood. Clinical Immunology 99: 94-99.

Strach M, Siedlar M, Kowalczyk D, Zembala M, Grodzicki T. (2006) Sepsis caused by Veillonella parvula infection in a 17 -year-old patient with $X$-linked agammaglobulinemia (Bruton's disease). J Clin Microbiol.; 44(7): 2655-2656.

Subauste CS. Primary immunodeficiencies and susceptibility to parasitic infections. Parasite Immunol. 2006;28:567-575.

Takada, H; Kanegane, H; Nomura, A; Yamamoto, K; Ihara, K; Takahashi, Y; et al. Female agammaglobulinemia due to Bruton's tyrosine kinase deficiency caused by extremely skewed X chromosome inactivation. Blood. 2004;103(1):185-187.

Takata M, Kurosaki T. A role for Bruton's tyrosine kinase in B cell antigen receptormediated activation of phospholipase C-y 2. J Exp Med. 1996;184:31-40. 
Tsukada S, Saffran DC, Rawlings DJ, Parolini O, Allen RC, Klisak I, et al. Deficient expression of a B cell cytoplasmic tyrosine kinase in human $\mathrm{X}$-linked agammaglobulinemia. Cell. 1993;72(2):279-290.

Usui K, Sasahara Y, Tazawa R, Hagiwara K, Tsukada S, Miyawaki T, et al. Recurrent pneumonia with mild hypogammaglobulinemia diagnose as $x$-linked agammaglobulinemia in adults. Respir Res. 2001;2:188-192.

Väliaho J, Smith $\mathrm{Cl}$, Vihinen M. BTKbase: the mutation database for X-linked agammaglobulinemia. Hum Mutat. 2006;27(12):1209-1217.

Velickovic M, Prasad ML, Weston SA, Benson EM. Identification of the Bruton's Tyrosine Kinase (BTK) gene mutations in 20 Australian families with $x$-linked agamaglobulinemia (XLA). Hum Mutat. 2004;23:398-399.

Vetrie D, Vorechovský I, Sideras P, Holland J, Davies A, Flinter F, et al. The gene involved in X-linked agammaglobulinaemia is a member of the src family of proteintyrosine kinases. Nature. 1993;361(6409):226-233.

Vihinen M, Vetrie D, Maniar HS, Ochs HD, Zhu Q, Vorechovsky I, et al. Structural basis of chromosome X-linked agammaglobulinemia: A tyrosine kinase disease. Proc Natl Acad Sci USA. 1994;91:12803-12807.

Vihinen M, Brandau O, Brandén LJ, Kwan SP, Lappalainen I, Lester T, et al. BTKbase, mutation database for $x$-linked agammaglobulinemia (XLA). Nucleic Acids Res. 1998;26:242-247.

Vihinen M, Mattsson PT, Smith CIE. Bruton's Tyrosine Kinase (BTK) in x-linked agammaglobulinemia (XLA). Front Biosci. 2000;5:d917-928.

Vihinen M, Arredondo-Vega FX, Casanova JL, Etizioni A, Giliani S, Hammarström L, et al. Primary immunodeficiency mutation databases. Adv Genet. 2001;43:103-188.

Winkelstein JA, Marino MC, Lederman HM, Jones SM, Sullivan KE, Burks AW, et al. 
X-linked Agammaglobulinemia: Report on a United State registry of 201 patients. Medicine. 2006;85:193-202.

Xu W, Harrison SC, Eck MJ. Three-dimensional structure of the tyrosine kinase cSrc. Nature. 1997;385:595-602.

Yang W, Desiderio S. Bap-135, a target for Bruton's tyrosine kinase in responde to B cell receptor engagement. Proc Natl Acad Sci USA. 1997;94:604-609.

Yong PF, Grosse-Kreul D, Maher J, Salisbury JR, Ibrahim MA. Dermatofibrosarcoma protuberans in a patient with X-linked agammaglobulinaemia. J Clin Pathol. 2007;60(10):1162-1164.

Yoshino A, Honda M, Kanegane H, Obata K, Matsukura H, Sakazume S. Membranoproliferative glomerulonephritis in a patient with X-linked agammaglobulinemia. Pediatr Nephrol. 2006;21(1):36-38.

Zelazko M, Carneiro-Sampaio MMS, Luigi MC, Olarte DG, Madrigal OP, Perez RB. Primary immunodeficiency diseases in Latin America: first report from eight countries participating in the LAGID. J Clin Immunol. 1998;18:161-166. 
Apêndices 


\section{Soluções}

\section{Solução de Lise}

1550 mM Cloreto de Amônia $\left(\mathrm{NH}_{4} \mathrm{Cl}\right)$

$100 \mathrm{mM}$ Bicarbonato de Potássio $\left(\mathrm{KHCO}_{3}\right)$

$10 \mathrm{mM}$ ÁcidoEtilenodiaminotetraacetato Sódico ( $\left.\mathrm{Na}_{2} E D T A\right)$

Agua Destilada

$500 \mathrm{ml}$

Ajustar o pH 7,4

\section{Solução de Extração}

75 mM Cloreto de Sódio (NaCl)

25 mM ÁcidoEtilenodiaminotetraacetato Sódico ( $\left.\mathrm{Na}_{2} E D T A\right)$

$1 \%$ Dodecil sulfato de sódio(SDS)

Agua Destilada

$500 \mathrm{ml}$

Ajustar o $\mathrm{pH} 8,0$

\section{Solução de TE}

10mM Tris- $\mathrm{HCl} \mathrm{pH} 8,0$

$1 \mathrm{mM}$ EDTA

Água Destilada

$10 \mathrm{ml}$

\section{Proteinase K}

Proteinase $\mathrm{K}$

$20 \mathrm{mg}$

Água destilada

$1 \mathrm{ml}$

Concentração de $20 \mathrm{mg} / \mathrm{ml}$ - Armazenar a 4ํㄷ 
PBS - Tampão Salina Fosfato

Cloreto de Sódio $(\mathrm{NaCl}) \quad 8 \mathrm{~g}$

Cloreto de Potássio $(\mathrm{KCl}) \quad 0,2 \mathrm{~g}$

Fosfato de Sódio $\left(\mathrm{Na}_{2} \mathrm{HPO}_{4}\right) \quad 1,44 \mathrm{~g}$

Fosfato de Potássio $\left(\mathrm{KH}_{2} \mathrm{PO}_{4}\right) \quad 0,24 \mathrm{~g}$

Água destilada $\quad 1.000 \mathrm{ml}$

Ajustar o $\mathrm{pH} 7,5$ - Autoclavar por 15 minutos a $121^{\circ} \mathrm{C}$

\section{Tampão TAE 50x}

Tris Base $242 \mathrm{~g}$

Ácido Acético Glacial $\quad 57,1 \mathrm{ml}$

0,5 M EDTA pH8,0 $100 \mathrm{ml}$

Água Destilada $\quad 1.000 \mathrm{ml}$

Solução Brometo de Etídio $10 \mathrm{mg} / \mathrm{ml}$

Brometo de Etídio $\left(\mathrm{C}_{21} \mathrm{H}_{2} \mathrm{OBrN}_{3}\right) \quad 0,2 \mathrm{~g}$

Água /destilada $20 \mathrm{ml}$

Armazenar a temperatura ambiente em local escuro

\section{0,5 M EDTA}

Ácido Etilenodiaminotetraacetato Sódico ( $\left.\mathrm{Na}_{2} \mathrm{EDTA}\right) \quad 186,1 \mathrm{~g}$

Água Destilada $\quad 1.000 \mathrm{ml}$

Ajustar o pH 8,0 - Autoclavar por 15 minutos a $121^{\circ} \mathrm{C}$ 
Dodecil Sufato de Sódio (SDS)

SDS

$10 \mathrm{~g}$

Água Destilada

$100 \mathrm{ml}$

Esterilizar por filtração

\section{Solução Desnaturante}

95\% Formamida 99\%

Xileno Cianol

$1 \mathrm{mg}$

Azul de Bromofenol

$10 \mathrm{mg}$

Água Destilada

$10 \mathrm{ml}$

Homogeneizar e armazenar a $4^{\circ} \mathrm{C}$ em frasco escuro

\section{Solução Fixadora}

10\% Etano absoluto

$30 \mathrm{ml}$

0,5\% Ácido acético

$0,5 \mathrm{ml}$

Água Destilada

$300 \mathrm{ml}$

Solução de uso imediato

Solução de Coloração

Nitrato de Prata

Água Destilada

$300 \mathrm{ml}$

Solução de uso imediato 


\section{Solução Reveladora}

Hidróxido de Sódio $(\mathrm{NaOH}) \quad 0,5 \mathrm{~g}$

Formaldeído $\quad 0,4 \mathrm{ml}$

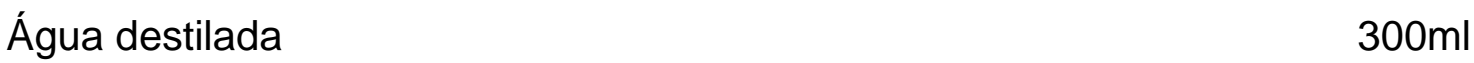

Solução de uso imediato 
Anexos 


\title{
TERMO DE CONSENTIMENTO LIVRE E ESCLARECIDO
}

\author{
ESTUDO: ESTUDO DAS MANIFESTAÇÕES CLÍNICAS, ALTERAÇÕES \\ LABORATORIAIS E DISTÚRBIOS GÊNICOS EM PACIENTES COM \\ AGAMAGLOBULINEMIA
}

Você está sendo convidado(a) a participar do projeto de pesquisa acima citado. O documento abaixo contém todas as informações necessárias sobre a pesquisa que estamos fazendo. Sua colaboração neste estudo será de muita importância para nós, mas se desistir a qualquer momento, isso não causará nenhum prejuizo a você.

Eu, ( inserir o nome, profissão, residente e domiciliado na .................., portador da Cédula de identidade, RG .......................... , e inscrito no CPF/MF.............................. nascido(a) em __ _ _ _ _ , abaixo assinado(a), concordo de livre e espontânea vontade em participar como voluntário(a) do estudo "Estudo das manifestações clínicas, alterações laboratoriais e distúrbios gênicos em pacientes com agamaglobulinemia". Declaro que obtive todas as informações necessárias, bem como todos os eventuais esclarecimentos quanto às dúvidas por mim apresentadas.

Estou ciente que:

I) O estudo se faz necessário para que se possam descobrir as possíveis causas da doença denominada Agamaglobulinemia (pacientes que possuem níveis de imunoglobulinas séricas muito baixos e ausência de células $B$ periféricas).

II) Será realizada uma coleta de sangue de $10 \mathrm{ml}$ que será distribuída em dois tubos: $5 \mathrm{ml}$ em tubo contendo EDTA e $5 \mathrm{ml}$ em tubo seco. Caso haja necessidade, serei convocado para uma nova coleta;

III) Essa (s) coleta(s) serão feitas apenas para este estudo e em nada influenciará (influenciarão) o meu tratamento; não vai (vão) me curar; não vai (vão) me 
causar nenhum problema, exceto o pequeno incômodo de dor no momento da coleta ( introdução da agulha para retirada do sangue)

IV) A participação neste projeto não tem objetivo de me submeter a um tratamento, bem como não me acarretará qualquer ônus pecuniário com relação aos procedimentos médico-clínico-terapêuticos efetuados com o estudo ;

V) Tenho a liberdade de desistir ou de interromper a colaboração neste estudo no momento em que desejar, sem necessidade de qualquer explicação;

VI) A desistência não causará nenhum prejuízo à minha saúde ou bem estar físico. Não virá interferir no atendimento ou tratamento médico;

VII) Os resultados obtidos durante este ensaio serão mantidos em sigilo, mas concordo que sejam divulgados em publicações científicas, desde que meus dados pessoais não sejam mencionados;

VIII) Caso eu desejar, poderei tomar conhecimento dos resultados ao final desta pesquisa;

( ) Desejo conhecer os resultados desta pesquisa.

( ) Não desejo conhecer os resultados desta pesquisa.

IX) Poderá contatar a Secretária do Comitê em Pesquisa com Seres Humanos do ICB/USP pelo telefone (11) 3091.7733 ou o pesquisador responsável Rosana Rezende de Oliveira pelo telefone (11) 3091.7435, para apresentar recursos ou reclamações em relação ao ensaio clínico.

São Paulo, de de 200 .

( ) Paciente / ( ) Responsável

Testemunha 1 :

Nome / RG / Telefone

Testemunha 2 :

Nome / RG / Telefone

Responsável pelo Projeto: 
Telefone para contato: (11) 3091.7435

\section{TERMO DE CONSENTIMENTO LIVRE E ESCLARECIDO}

(menores de 18 anos)

\section{ESTUDO: ESTUDO: ESTUDO DAS MANIFESTAÇÕES CLÍNICAS, ALTERAÇÕES \\ LABORATORIAIS E DISTÚRBIOS GÊNICOS EM PACIENTES COM}

AGAMAGLOBULINEMIA

Seu filho está sendo convidado a participar do projeto de pesquisa acima citado. $O$ documento abaixo contém todas as informações necessárias sobre a pesquisa que estamos fazendo, então leia atentamente e caso tenha dúvidas, vou esclarece-las (se não souber ler, fique tranquilo(a) que leio para você). Se concordar, o documento será assinado e só então daremos início a pesquisa. Sua colaboração neste estudo será de muita importância para nós, mas se desistir a qualquer momento, isso não causará nenhum prejuízo a você, nem ao seu (sua) filho(a).

Eu.

residente á

RG abaixo assinado(a), concordo de livre e espontânea vontade que meu(minha) filho(a) nascido(a) em 1 , seja voluntário do estudo "Estudo das manifestações clínicas, alterações laboratoriais e distúrbios gênicos em pacientes com agamaglobulinemia", esclareço que obtive todas informações necessárias e fui esclarecido(a) de todas as dúvidas apresentadas.

Estou ciente que:

I. O estudo se faz necessário para que possam descobrir as possíveis causas da doença denominada Agamaglobulinemia (pacientes que possuem níveis de imunoglobulinas séricas muito baixos e ausência de células $B$ periféricas);

II. Será realizada uma coleta de sangue de até $10 \mathrm{ml}$ que será distribuída em dois tubos: até $5 \mathrm{ml}$ em tubo contendo EDTA e até $5 \mathrm{ml}$ em tubo seco. Caso haja necessidade, meu (minha) filho (a) será convocado para uma nova coleta. Nos casos das crianças 
menores com peso corpóreo inferior a $10 \mathrm{Kg}$, realizaremos coletas com quantidades menores de sangue;

III. Essa coleta será feita apenas para este estudo e em nada influenciará no tratamento de meu (minha) filho(a); não vai curá-lo (a); não causará nenhum problema, exceto a dor da picadinha da agulha no local da coleta;

IV. A participação neste projeto não tem objetivo de se submeter a um tratamento terapêutico e será sem custo algum para mim;

V. Tenho a liberdade de desistir ou interromper a colaboração neste estudo no momento em que desejar, sem necessidade de qualquer explicação;

VI. A desistência não causará nenhum prejuízo a mim, nem ao(a) meu (minha) filho(a), e sem que venha interferir no atendimento ou tratamento médico;

VII. Os resultados obtidos durante este ensaio serão mantidos em sigilo, mas concordo que sejam divulgados em publicações científicas, desde que nem o meu nome nem o de meu filho sejam mencionados;

VIII. Caso eu desejar, poderei tomar conhecimento dos resultados ao final desta pesquisa;

i. ( ) Desejo conhecer os resultados desta pesquisa.

ii. ( ) Não desejo conhecer os resultados desta pesquisa.

IX. Poderá contatar a Secretária do Comitê em Pesquisa com Seres Humanos do ICB/USP pelo telefone (11) 3091.7733 ou o pesquisador responsável Rosana Rezende de Oliveira pelo telefone (11) 3091.7435, para apresentar recursos ou reclamações em relação ao ensaio clínico.

São Paulo, de de 200_.

\section{( ) Paciente / ( ) Responsável}

Testemunha 1 :

Nome / RG / Telefone

Testemunha 2 :

Nome / RG / Telefone

Responsável pelo Projeto:

Rosana Rezende de Oliveira

Fone: (11) 3091.7435 
Tabela 6. Relação dos pares de iniciadores sintetizados para amplificação de cada exon do gene btk, temperatura de melting e tamanho do produto amplificado.

\begin{tabular}{|c|c|c|c|c|}
\hline Exon & Iniciador & Seqüência $\left(5^{\prime} \rightarrow 3^{\prime}\right)$ & $\begin{array}{l}\text { T.A. } \\
\text { (ㅇ) }\end{array}$ & Produto (bp) \\
\hline \multirow[t]{2}{*}{1} & Forward & AACTGAGTGGCTGTGAAAGG & 55 & 212 \\
\hline & Reverse & AAGGTACATTGCTGCTGCTG & & \\
\hline \multirow[t]{2}{*}{2} & Forward & CCATTTGAAACTAGGTAGCT & 55 & 311 \\
\hline & Reverse & GGCCAAGTCCTTGATATCTT & & \\
\hline \multirow[t]{2}{*}{3} & Forward & CTGGTTGCTTAATCCCTCTT & 55 & 249 \\
\hline & Reverse & GCACAGCATCACCAGTCTAT & & \\
\hline \multirow[t]{2}{*}{4} & Forward & GCAATGCATCAACCAATAAC & 56 & 215 \\
\hline & Reverse & TATTCACTGGGTCCTCGTAG & & \\
\hline \multirow[t]{2}{*}{5} & Forward & CCTAACTGCTGAAGTCTGTG & 58 & 184 \\
\hline & Reverse & CGCTTCCTTAGTTCTTCAGT & & \\
\hline \multirow[t]{2}{*}{6} & Forward & GCTTCTCCTCCATGTCAGAT & 52 & 202 \\
\hline & Reverse & CAAGCTTATCGATCAGATTG & & \\
\hline \multirow[t]{2}{*}{7} & Forward & AAGTCCCTGACCAAACCTGT & 58 & 210 \\
\hline & Reverse & TGTGTTCTTAGGGCTTGACT & & \\
\hline \multirow[t]{2}{*}{8} & Forward & GAGTGCTTGGTATCTTGACA & 58 & 294 \\
\hline & Reverse & TTGCGTGTAGGGAGTGGGC & & \\
\hline \multirow[t]{2}{*}{9} & Forward & ATGAATCTGTCTCCTGGAGG & 58 & 160 \\
\hline & Reverse & CTGGAAGATTGTGGACTGAC & & \\
\hline \multirow[t]{2}{*}{10} & Forward & CCTCCAATCTGCTTATGACC & 58 & 159 \\
\hline & Reverse & GATCCTCACTTATGCAAGGA & & \\
\hline \multirow[t]{2}{*}{11} & Forward & TCCTCCTACAGACAGCTTCT & 56 & 183 \\
\hline & Reverse & GCATCAAGGAGCTATTAGGA & & \\
\hline \multirow[t]{2}{*}{12} & Forward & CATCTCACTTCACTTCCTGG & 58 & 253 \\
\hline & Reverse & GCATTGCTTATCCTGGTGTC & & \\
\hline \multirow[t]{2}{*}{13} & Forward & AGTGAGGATGTGTGAGGCAT & 58 & 239 \\
\hline & Reverse & CACAGTGTACCTCAAGGACA & & \\
\hline 14 & Forward & ATGACCCCAAAGAATCACAC & 55 & 265 \\
\hline
\end{tabular}




\begin{tabular}{ccccc}
\multicolumn{7}{c}{ Reverse } & GTGAATTCCTAGACTCCAG & & \\
\hline 15 & Forward & GCCAAAAGGAGAAGACTAGTT & 55 & 212 \\
& Reverse & TCTTCCACTGCTACTTCCAC & & \\
\hline 16 & Forward & GTGCCTTTAACCTCTGTGCT & 55 & 185 \\
& Reverse & TACCCATGTTTCATGCTGTG & & \\
\hline 17 & Forward & CCTCCAAATCCTAATGCAAC & 55 & 244 \\
& Reverse & CTCTGTGGAGGTTGCAAAGT & & \\
\hline 18 & Forward & TTGAGGTTGATCTAGGAAGA & 52 & 329 \\
& Reverse & GCAGCTATCAGTCTTTGGTG & & \\
\hline 19 & Forward & GGATTCTAGCCACTCTAACA & 52 & 187 \\
& Reverse & GGATTTCCTCTGAGAAAGTG & & \\
& &
\end{tabular}

Fonte: GenBank - HSU78027

Tabela 7. Relação dos pares de iniciadores interexons, sintetizados para reação de transcriptase reversa do gene btk, temperatura de melting e tamanho do produto amplificado.

\begin{tabular}{ccccc} 
Gene & Iniciador & $\begin{array}{c}\text { Seqüencia }\left(5^{\prime} \rightarrow 3^{\prime}\right) \\
\end{array}$ & $\begin{array}{c}\text { T.A. } \\
\left({ }^{\circ} \mathbf{C}\right)\end{array}$ & Produto (bp) \\
\hline$b t k$ & Forward & CTC ATC TGG CTT CAG AGA AGG & 60 & 463
\end{tabular}

Reverse GGG CTT GTG GAG AAG AGA

AGT A

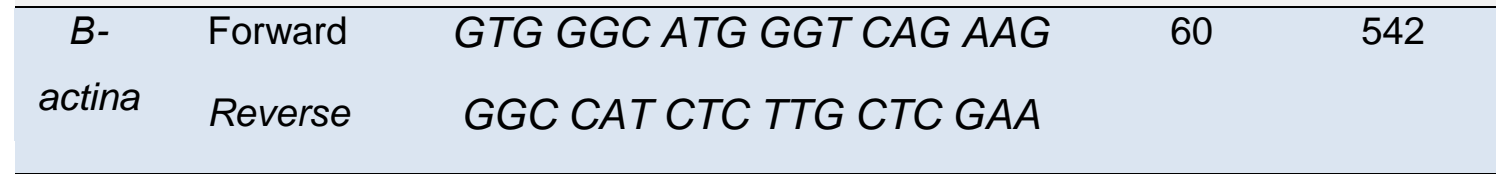

Fonte: Genbank - gene btk, mRNA X58957 e gene B-actina, mRNA NM001101. 
Tabela 7. Relação dos pares de iniciadores interexons, sintetizados para reação de real-time do gene btk, temperatura de melting e tamanho do produto amplificado.

$$
\text { Gene Iniciador Seqüência }\left(5^{\prime} \rightarrow 3^{\prime}\right)
$$

\begin{tabular}{|c|c|c|c|c|}
\hline Gene & Iniciador & Seqüência $\left(5^{\prime} \rightarrow 3^{\prime}\right)$ & $\begin{array}{l}\text { T.A. } \\
\left({ }^{\circ} \mathrm{C}\right)\end{array}$ & Produto (bp \\
\hline btk & Forward & $\begin{array}{c}\text { CTC ATC TGG CTT CAG AGA AGG } \\
\qquad \mathrm{T}\end{array}$ & 60 & 170 \\
\hline
\end{tabular}

Reverse GGG CTT GTG GAG AAG AGA
AGT A

\begin{tabular}{|c|c|c|c|}
\hline$B-$ & Forward & TCA CCG AGC GCG GCT & 60 \\
\hline actina & Reverse & TAA TGT CAC GCA CGA TTT CCC & \\
\hline
\end{tabular}

Fonte: Genbank - gene btk, mRNA X58957 e gene B-actina, mRNA NM001101. 